\title{
Understanding place brands as collective and territorial development processes
}
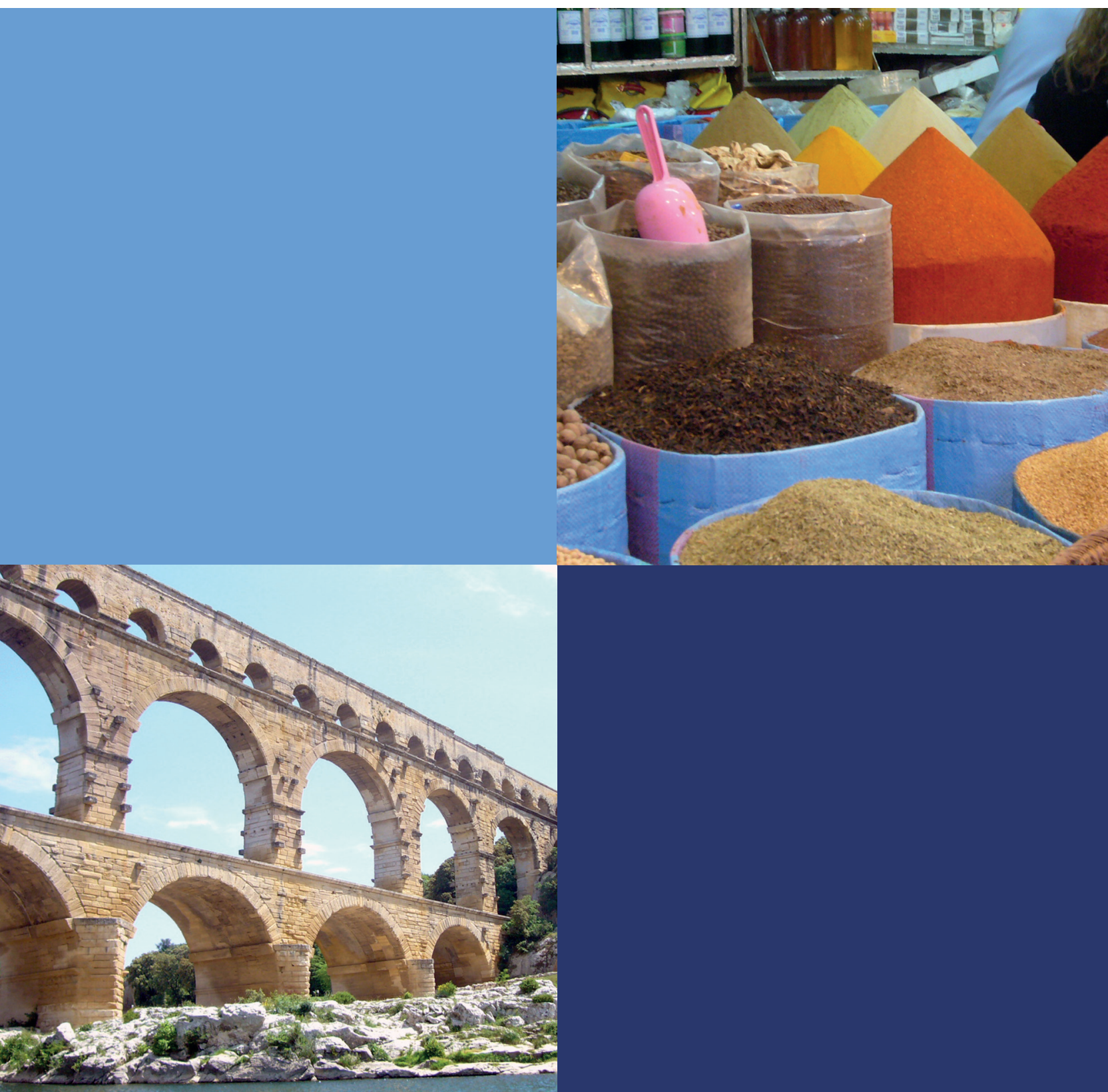



\section{Understanding place brands}

as collective and territorial development processes

Mechthild Irmgard Maria Donner 


\section{Thesis committee}

\section{Promotors}

Prof. Dr F. Fort

Professor

Montpellier SupAgro - IRC

Prof. Dr C. Leeuwis

Professor of Knowledge, Technology and Innovation

Wageningen University

\section{Co-promotor}

Dr Ir. S.R. Vellema

Associate professor, Knowledge, Technology and Innovation Group

Wageningen University

\section{Other members}

Prof. Dr J.S.C. Wiskerke, Wageningen University

Dr D. Sautier, CIRAD, Montpellier, France

Dr A. Kalandides, INPOLIS, Berlin, Germany

Prof. Dr V.R. van der Duim, Wageningen University

This research was conducted under the auspices of the Doctoral School of Economics and Management (École Doctorale Économie et Gestion - EDEG) Montpellier, France, and Wageningen School of Social Sciences (WASS), The Netherlands, and as part of the joint Erasmus Mundus PhD programme AGricultural TRansformation by INnovation (AGTRAIN). 


\title{
Understanding place brands
}

\section{as collective and territorial development processes}

\author{
Mechthild Irmgard Maria Donner
}

\section{Thesis}

submitted in fulfilment of the requirements for the joint degree of Doctor between

Montpellier SupAgro

by the authority of the Directrice Générale,

Dr A.L. Wack,

and

Wageningen University

by the authority of the Rector Magnificus,

Prof. Dr Ir. A.P.J. Mol,

in the presence of the

Thesis Committee appointed by the Academic Boards of both universities

to be defended in public

on Friday 10 June 2016

at 11 a.m. in the Aula of Wageningen University 
Mechthild Irmgard Maria Donner

Understanding place brands as collective and territorial development processes 178 pages

Joint PhD thesis, Montpellier SupAgro, France, and Wageningen University, Wageningen, The Netherlands (2016)

With references and with summaries in English, French, Dutch and German

ISBN: 978-94-6257-799-2

DOI http://dx.doi.org/10.18174/379598 
To Huug and Annabelle 


\section{Acknowledgements}

The research reported in this book was carried out in the framework of the Agricultural Transformation by Innovation Erasmus Mundus Joint Doctorate Program (AGTRAIN; www.agtrain.eu), funded by the EACEA (Education, Audiovisual and Culture Executive Agency) of the European Commission. My sincere thanks go to the coordinators of the AGTRAIN program, Andreas de Neergaard and Didier Pillot, and to Ida Marie Krogager, Corinne Pickett and Madeleine Aidi, for their administrative support.

I would like to express my special thanks to my supervisors Fatiha Fort and Sietze Vellema. I gratefully thank them both for encouraging me in doing this research and for helping me to become a scientist. I especially appreciated the pleasant common days of field work in Morocco with both of them. Fatiha, without your support from the beginning I would not have had the opportunity to realise my thesis. Your enthusiasm, scientific advice and profound understanding throughout the years are greatly appreciated. Sietze, thank you very much for the scientific discussions and for your valuable comments, your patience and humour until the day of finalizing the thesis.

I like to acknowledge Cees Leeuwis for his constructive remarks as promotor and his group for making a $4^{\text {th }}$ thesis year possible.

I am grateful to the annual thesis committee members in Montpellier, Jean-Louis Rastoin, Angèle Postolle and Christophe Touzard, for their interest in my research and continuous advice. A special thanks to Jean-Louis Rastoin who strongly supported my project since I came to Montpellier in 2010.

I acknowledge Ina Horlings for her cooperation and for her human way of exchanging ideas. Ina, your sociological perspective on place branding was extremely enriching for me.

My gratitude goes to people from Morocco, whose support and cooperation were highly valuable for my research. Especially, I would like to thank Mohamed Ater (University of Tétouan), Rachid Hamimaz (Institute of Agronomy and Veterinary Medicine Hassan II, Rabat) and Mohamed Larbi Sidmou (University of Marrakech) for their interest in my research, warm welcome and all the information. I also thank Elias Afassi and Azzedine Azouzi for guiding me in the field and making me learn many things about their wonderful country. 
I present my sincere thanks to all the people interviewed during my research, in the LanguedocRoussillon region, in Morocco and in the Black Forest; without their cooperation and discussions the research would not have been possible.

Thanks also to the colleagues and staff at the universities Montpellier SupAgro and Wageningen and to the research groups UMR MOISA (markets, organizations, institutions and stakeholders strategies) and KTI (Knowledge, Technology and Innovation) where I have carried out my research. Particularly, I would like to thank the IRC and Jacques Maillet for welcoming me at the institute from the beginning onwards.

My Agtrain fellows were also essential for me, providing exchange and friendship. It was wonderful to share the Uganda field work experience with all of you. Uta and Anna, thank you for spending hilarious moments together in the past 4 years.

My friends across Europe have been a continuous support; they have accompanied my ongoing search for new challenges with amazement and interest. Thank you Melissa, Stephanie, Birgit, Kathi, Susan, Marion, Jens, Cuqui, Alba, Monika and others for your friendship.

Hartelijke dank Sylbi and Hugo, my Dutch family, without your practical help and warm welcome in 'sometimes rainy' Holland I would have hardly managed to combine research in Wageningen and own family life.

I have to thank especially my family in Germany for their love and moral support. I am deeply grateful to my parents who have always enabled and encouraged me to follow my interests, to be open for other cultures and to consider life as a continuous enriching learning process. Mutter und Vater, vielen Dank für alles was ihr für mich getan habt. Thanks Judith for sharing your 'Echt Schwarzwald' passion and experience with me.

Finally, Huug and Annabelle, words cannot describe what you both mean to me. Thank you so much Huug for your love, your support and for many valuable discussions, your patience and understanding. Annabelle, you are the strongest, most wonderful and vibrant daughter I could ever imagine. I feel sorry for the days we were apart because of my studies.

\section{Mechthild Donner}

Montpellier, May 2016 


\section{Table of contents}

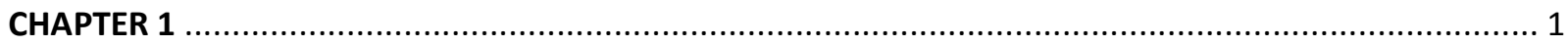

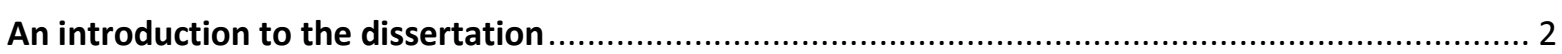

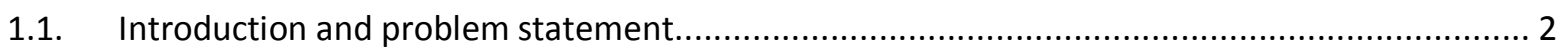

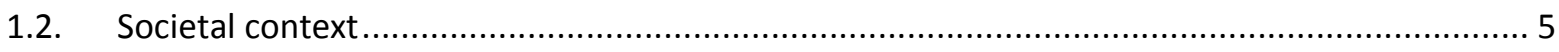

1.2.1. The importance of place-based marketing in a global context............................................ 5

1.2.2. Regionalisation and decentralisation processes in Europe and Morocco .................................... 7

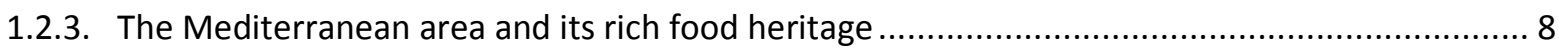

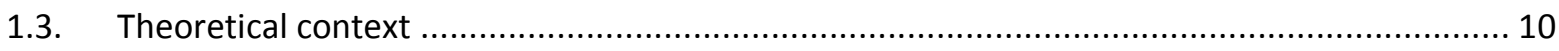

1.3.1. Place marketing and branding: origin, state-of-the-art in literature and critics....................... 10

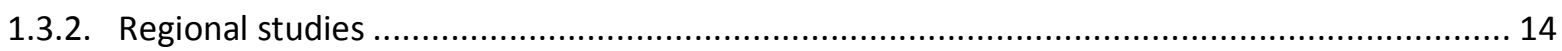

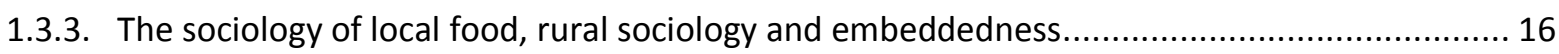

1.3.4. Conceptual diagram: linking marketing, regional studies and sociology ................................ 17

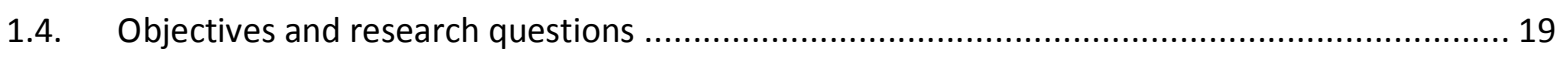

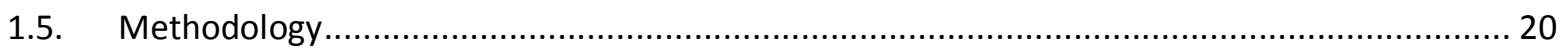

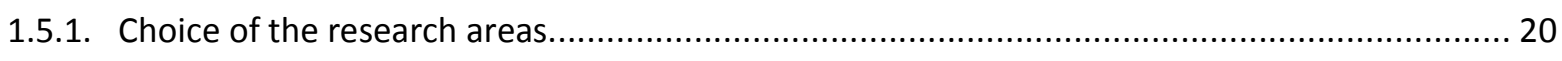

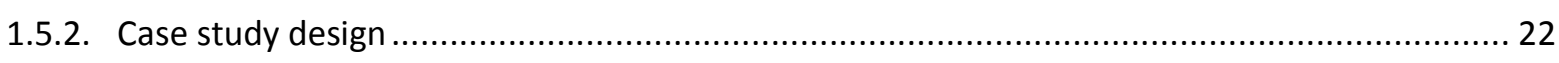

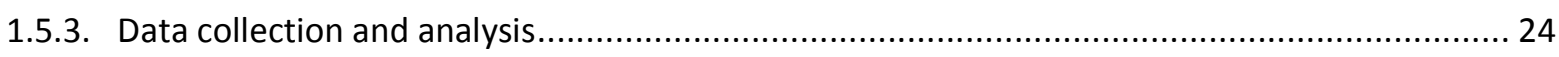

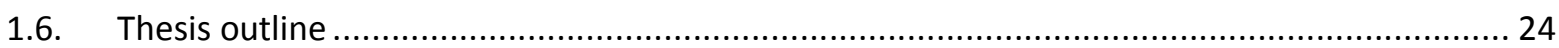

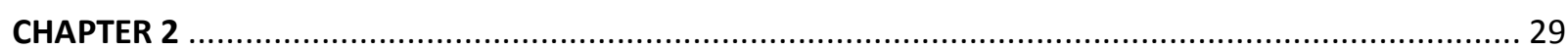

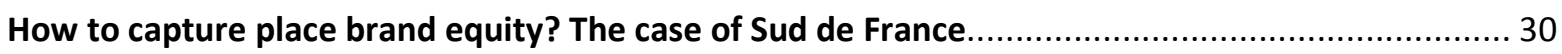

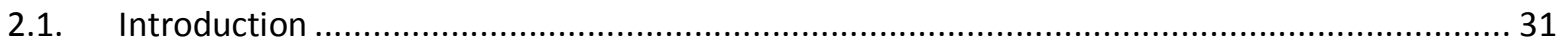

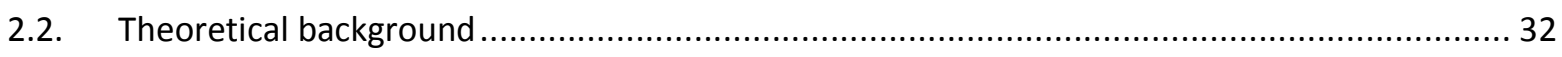

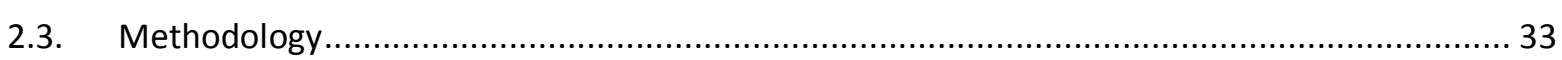

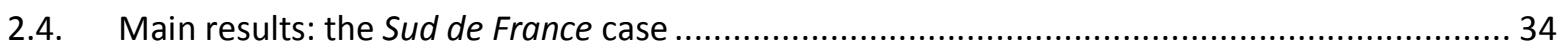

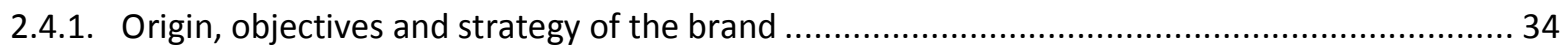

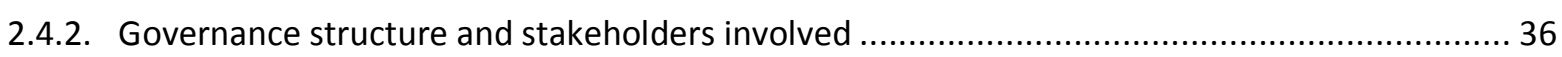

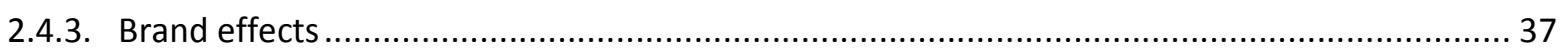

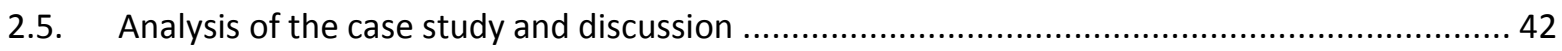

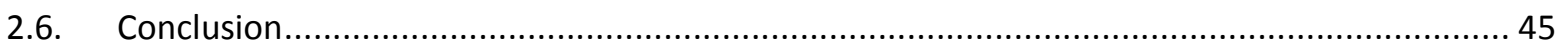


What kind of value for place brands? A stakeholder approach .................................................. 50

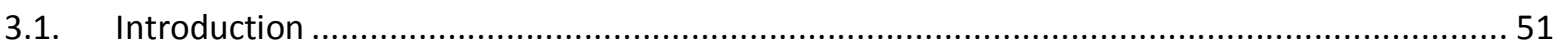

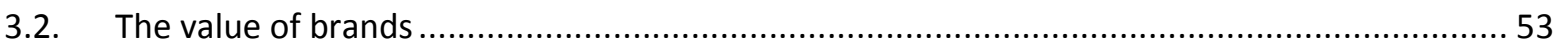

3.3. From identifying place brand stakeholders towards a monitoring tool.................................. 56

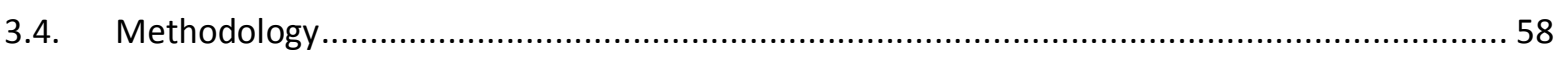

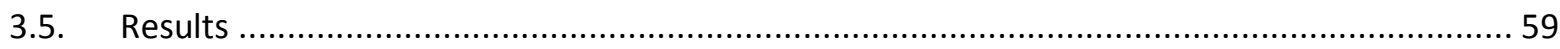

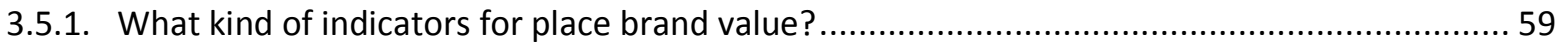

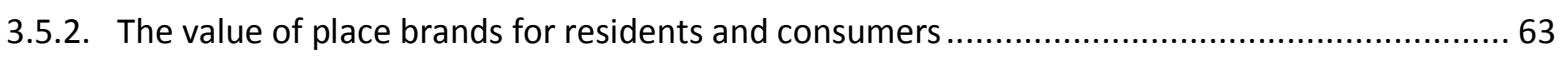

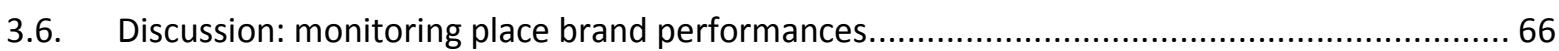

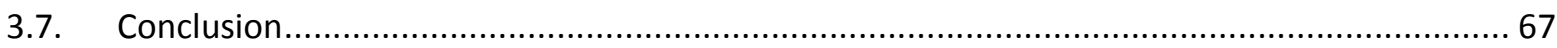

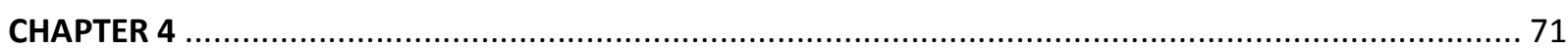

Place branding, embeddedness and rural development: Four cases from Europe ......................... 72

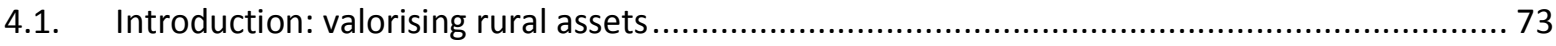

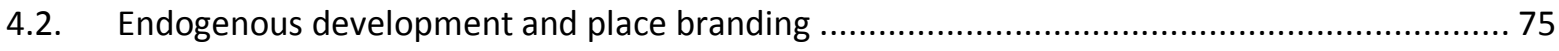

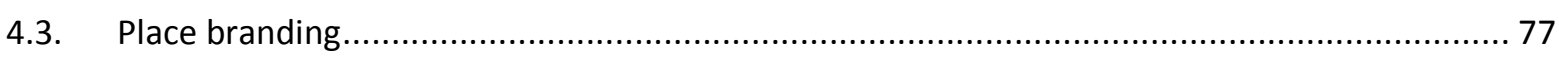

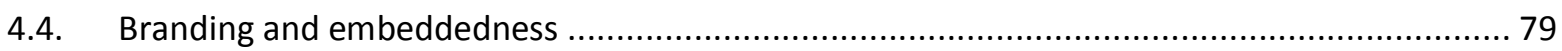

4.5. Methodology

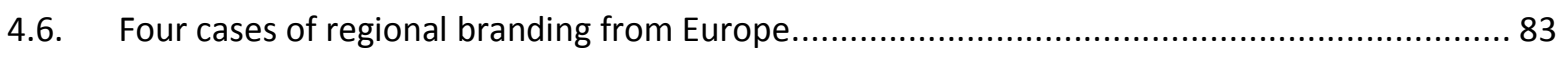

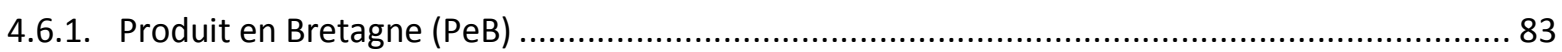

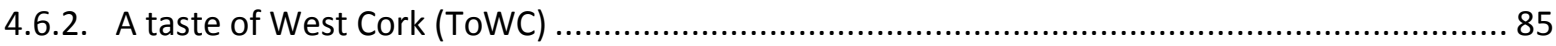

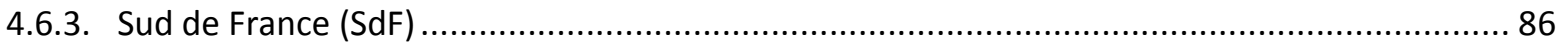

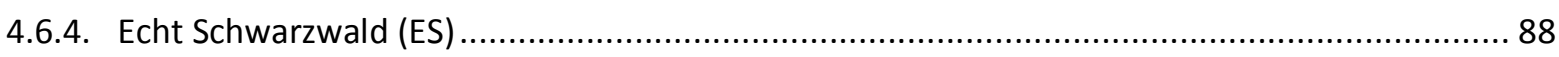

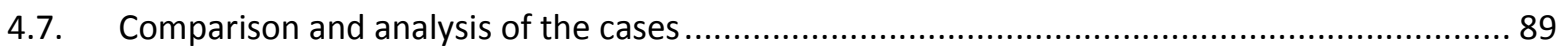

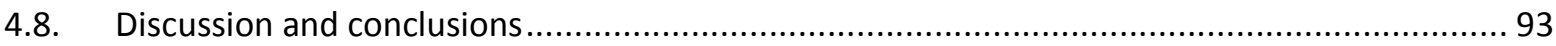

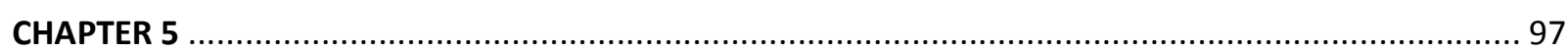

Co-creating territorial development and cross-sector synergy: A case study of place branding in

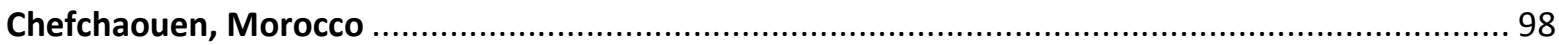

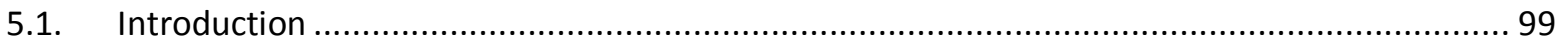

5.2. Policy frameworks for development in France and Morocco............................................... 101

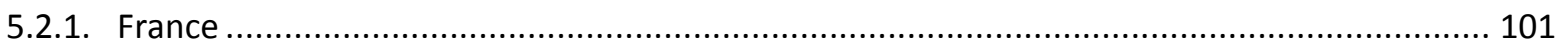

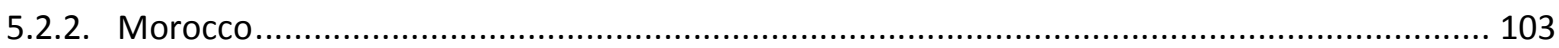

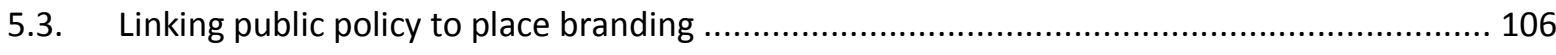

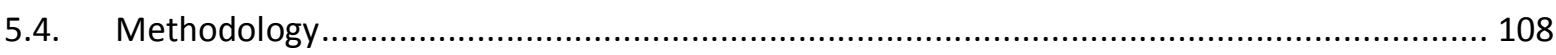


5.4.1. Case study of territorial development................................................................ 108

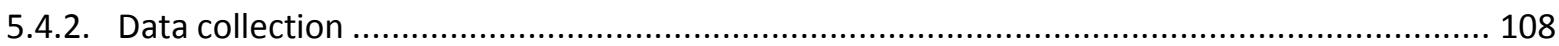

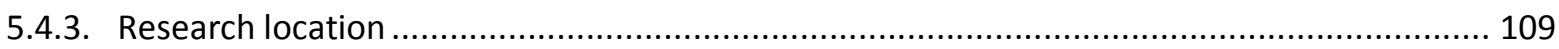

5.5. Co-creation in Chefchaouen ......................................................................... 109

5.5.1. The sequence of events leading to a place branding project in Chefchaouen ..................... 110

5.5.2. Examples of joint actions building a territorial image of Chefchaouen .............................. 112

5.6. Analysis of the case study ...................................................................... 114

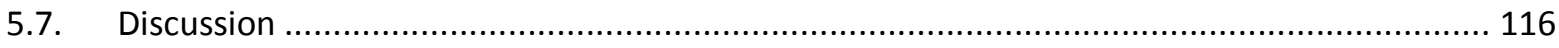

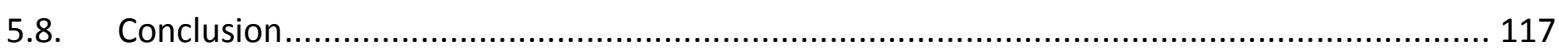

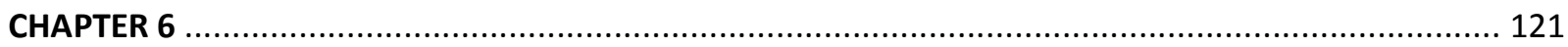

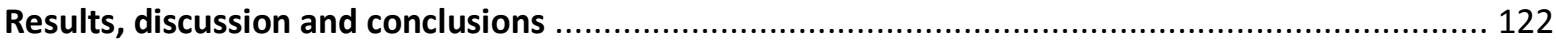

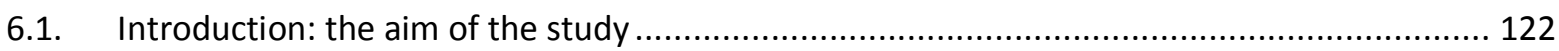

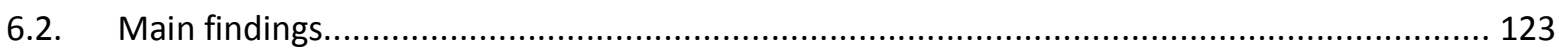

6.3. Conceptualising and theorising collective place brands.............................................. 125

6.3.1. The collective place branding concept ............................................................. 126

6.3.2. Conditions, dynamics and processes of collective place branding .................................. 129

6.3.3. Assessing territorial development outcomes of collective place brands .......................... 132

6.4. Methodological implication: case study approach to collective place brands .................... 134

6.5. Practical implications for development policies and place brand management ................... 135

6.6. Suggestions for further research....................................................................... 136

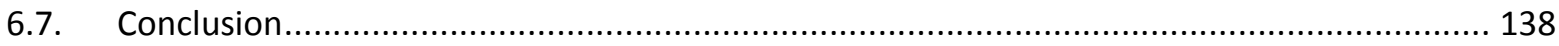

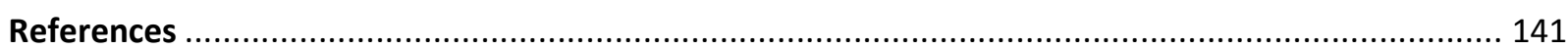

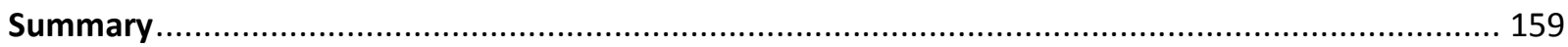

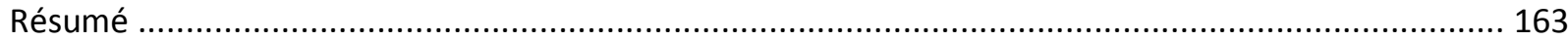

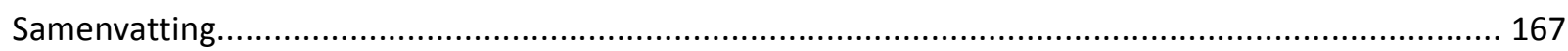

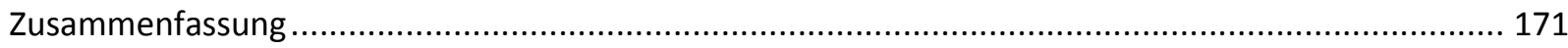

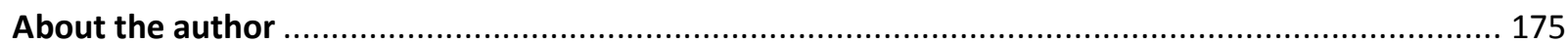

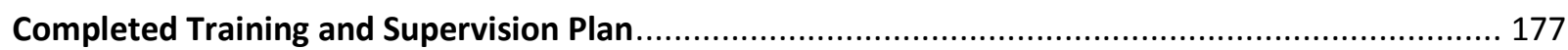

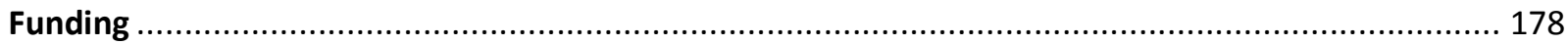




\section{List of tables}

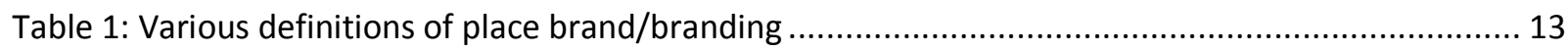

Table 2: Purposes and types of case studies and their application in this thesis................................... 23

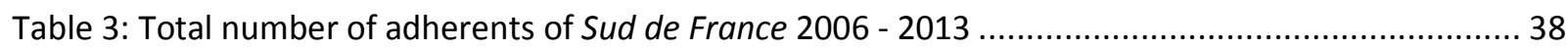

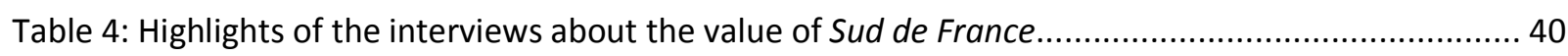

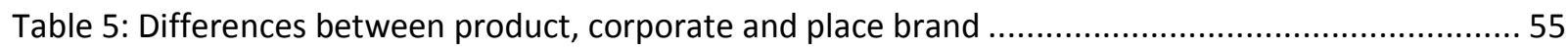

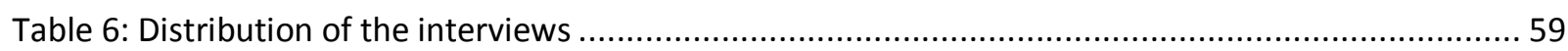

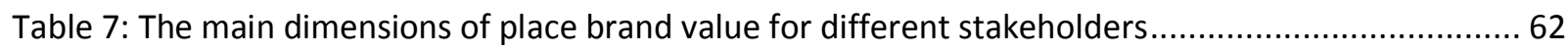

Table 8: List of items to measure place brand value among consumers and residents .............................64

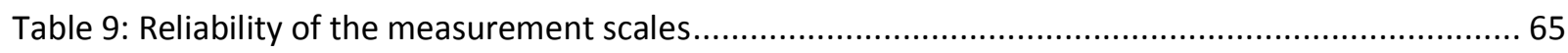

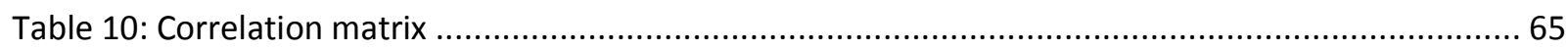

Table 11: Overview of the regional brands with regard to embeddedness ........................................... 92

Table 12: Framework: factors for success or failure in place branding ............................................ 107

Table 13: Time path of the events and activities leading to place branding in Chefchaouen ................. 110

Table 14: Typology of place brands (with examples from France) .................................................. 128

Table 15: Implications of the research findings on development policies and brand management ....... 135

\section{List of figures}

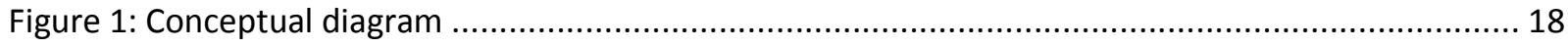

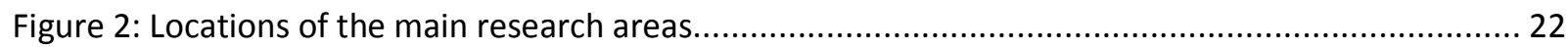

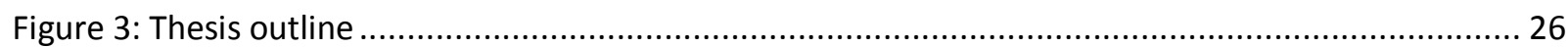

Figure 4: Positioning of the main stakeholders of the brand Sud de France .......................................... 37

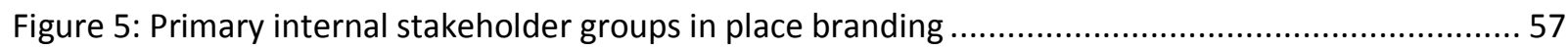

Figure 6: A 'novel' Balanced Scorecard as monitoring tool for the performance of place brands ............ 66

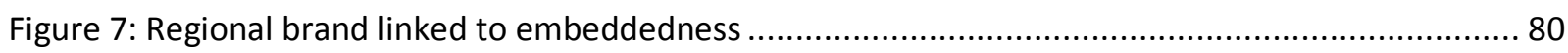

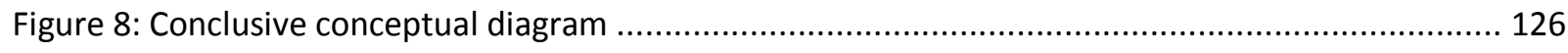

Figure 9: The iterative process of assessing collective place branding outcomes ............................... 133 
An introduction to the dissertation 


\section{Chapter 1}

\section{An introduction to the dissertation}

\subsection{Introduction and problem statement}

Over the last two decades, the application of marketing and branding strategies for destinations has become increasingly popular. Some prominent examples of European city and nation brands are I amsterdam, be Berlin, OnlyLyon, La Belle France, Germany - land of ideas, Marca España. Places of origin are also used for adding-value, protecting and marketing local products. For food products this is often done via geographical indications (GIs), such as Parma Ham, Roquefort cheese, Cognac, Bordeaux. All these strategies combine place and brand and have a common feature in that they exploit the unique and distinctive characteristics of a place and/or its assets for commercial purposes.

Linking marketing to places is not a new phenomenon. In the context of globalisation, place branding has become increasingly part of public agendas and intervention strategies. It is used for the communication of identities and values or as a spatial planning and development instrument. This expresses an intention to manage places in a business-like manner, as a modern 'entrepreneurial style of local government' and economic development (Harvey 1989, Kavaratzis 2005). Place branding strategies are also used by (small) economic actors in order to valorise and market local products and to strengthen their competitiveness within a global marketplace. Place brands can be created on different geographical scales (nations, regions, state departments, communities, cities), within and across administrative boundaries. The general assumption is that place branding has the potential to contribute to the 'economic, social, political and cultural developments of cities, regions and countries', which is central to the orientation of scholarly work in this emerging field that is published in the Journal of Place Branding and Public Diplomacy.

Reviewing the proliferation of place brands in Europe, one can state that the use of place identity for marketing purposes has become commonplace. The multiplicity of place branding initiatives also reveals their enormous diversity: they can have various objectives and strategies, aim at different target sectors and groups, and combine different forms of cooperation and governance. Often, various place brands even co-exist within the same territory, but without necessarily being 
well-articulated or coherent. The French region Alsace is a good example, as there are about 25 different brands related to the place - for the region, its departments and cities - with different aims and for various sectors. ${ }^{1}$ A review on the development of regional branding initiatives in Germany by the worldwide advertising agency BBDO (Batten, Barton, Durstine \& Osborn) has found an enormous increase from 123 registered initiatives in 1996 to 394 in 2002. This demonstrates the boom in the various marketing activities related to place. ${ }^{2}$

In this 'jungle' of different place marketing and branding initiatives that actually take place, there is a need to further conceptualise this phenomenon.

At a regional level, at least three types of place-based brands can be observed and differentiated. The first type comprises GIs that are used as a way to collectively valorise and market local food products. GIs are developed worldwide and have received a lot of attention. However, they concern mono-products and do not combine different local products and services. A second type of place brands exists which is institutional, and primarily aims at the attraction of foreign investors, immigrants and tourists, to increase the attractiveness of a place and stimulate economic development. Finally, a third type is collectively used to valorise, promote globally, and protect a variety of place-specific (material and immaterial) assets via an umbrella place branding strategy, such as local quality products (often food) and services, natural landscapes, historical sites, cultural heritage and local values. This third, collective place branding type has been of prime interest for this thesis, although interestingly, one of the cases investigated, Sud de France, combines the last two types.

As a widespread and growing empirical practice, place branding has attracted the interest of many scholars over the past two decades. However, this has neither led to a commonly accepted definition nor to a clear conceptualisation. Papadopoulos ${ }^{3}$ critically states that, "at the base we don't even know what we're talking about - there are no widely accepted definitions of the key terms, for example... today the field of country branding research resembles the Wild West model: anything goes." Warnaby et al. (2015: 241) also point out that place branding urgently

\footnotetext{
${ }^{1}$ Cf. Virginie Mahé: Document presented during the Marketing Business Meeting of the 'Association Tunisienne des Professionnels du Marketing et de la Communication' - Sousse (Tunisia) - 29-30 April 2013.

${ }^{2}$ Online document of the BBDO consulting (16/07/2003): Analyse ausgewählter Regionalmarken.

${ }^{3}$ Nicolas Papadopoulos (marketing professor at Carleton University and among the first to conduct research on country image and country-of-origin effects), in the expert interview series of the placebrandobserver.com on 10 December 2015.
} 
needs "a rethinking in terms of its origins, theoretical underpinnings, conceptual development, practical applications and expected outcomes".

Another important point, put forward by Pasquinelli (2012), is that place branding and marketing are usually approached from a market and business perspective, considering places as locations of exchange between offers (of the place-specific territorial assets) and demand (by consumers, i.e. residents, tourists, foreign investors). However, places can also be interpreted from another point of view, e.g. 'as a bundle of internal relations', which allows 'widening the perspective on place branding' (Pasquinelli 2012).

The increasing importance, but acknowledged shortcomings, in science, and the significant growth of different place branding activities, call for a further exploration of this rich and complex phenomenon, both in theory and in practice. Accordingly, this thesis seeks to contribute to the clarification of the place branding concept on the one hand, and to a broader understanding of the phenomenon on the other, by approaching place brands not only from a market and business perspective (as is often done). It sets the focus on the underlying conditions, processes and dynamics that explain how place branding in regions functions in a way that it contributes to territorial development.

The thesis investigates place branding related to local food products and tourism for sustainable territorial development in Mediterranean rural regions (France and Morocco). The Mediterranean basin is a geographical area where the food and tourism sectors are highly important in terms of employment and incomes. Branding local food is also relevant, as it makes us think about our food habits, our culturally rich food heritage, and the future of our food.

The remainder of the introduction chapter is structured as follows: first, the societal context of place branding is presented to explain the economic, political and socio-cultural relevance of this research project; then, the theoretical context is introduced, in which marketing is linked to regional studies and sociological perspectives on food and rural development, in order to provide a broader perspective on place branding; thereafter, the objectives and research questions are specified; and finally, it is explained why case study was chosen as the main methodology. The introduction ends with the thesis outline. 


\subsection{Societal context}

Place branding in this thesis is positioned within the following societal context: (1) globalisation as a challenge for (rural) regions and a driver for diverse marketing activities linked to places; (2) the regionalisation and decentralisation processes in Europe and Morocco obliging local authorities to take responsibility for territorial development; and (3) the externalities of globalisation and regionalisation on the Mediterranean basin and its food heritage.

\subsubsection{The importance of place-based marketing in a global context}

Within an increased complex world characterised by globalisation - i.e. trade liberalisation and homogenisation of economic markets, capital and labour mobility, improvement of transportation and communication technologies - local economies are being transformed. Global competition puts pressure on product and service companies as well as on places themselves. In particular, rural regions (that are here addressed) face severe economic and social challenges and vulnerabilities which are embedded in these wider processes of globalisation. As a response, many places have started to differentiate and promote themselves by developing their own brands. The need to attract tourists, companies and skilled people, and to find export markets for products, has required places to adopt marketing and branding strategies (Kotler \& Gertner 2002). At present, many and diverse place brands appear worldwide. They can encompass various dimensions, such as local businesses and their (export) products, culture and heritage, tourism, governance, people, and/or investment (Anholt 2006). Thereby, place branding can either follow a holistic (encompassing) strategy or favour one or more sectors or dimensions. The application area usually depends on the competences, available distinctive assets and development objectives of a place.

In rural areas, agricultural and food products form an essential part of distinctive assets. Indeed, the communication of food product quality based on geographical origin has become an established value-adding strategy in the global trade, often framed by international policies and regulations. Hence, place-based marketing strategies accompanied by new or alternative forms of governance, including for food, have gained significance.

For example, the EU has developed a common legal framework for official signs that highlight agricultural and food product quality based on origin, and differentiates between three types of 
GIs: PDO (protected designation of origin), PGI (protected geographical indication) and TSG (traditional specialty guaranteed). ${ }^{4}$ The WTO (World Trade Organisation) has recognised GIs as intellectual property rights on the same basis as commercial brands (Trade-Related Aspects of Intellectual Property Rights, TRIPs Agreements 1994). This has strengthened their status and contributed to their international expansion.

GIs are also in the nature of brands, but, unlike brands, do not indicate the source of a particular manufacturer. GIs guarantee the location from which a particular quality of a good originates. Unlike brands, GIs are inalienable (i.e. they cannot be sold or give a user licence) and are based on public law. They aim to protect producers and consumers from fraudulent use of the product name. GIs have received a lot of attention in practice, being promoted worldwide by the EU and the FAO, and they have also generated a large body of literature in the scientific domain. GIs are challenging and interesting in the sense that those who produce and market them must engage in collective action "with regard to production methods, quality standards and control, as well as product distribution and marketing." up approach. ${ }^{6}$

Apart from these official signs within international agricultural trade policies, other collective brands can be applied for product differentiation based on origin and/or quality. Unlike an individual brand, a collective brand is simultaneously used by different enterprises (producers, processors) which are not necessarily the owners of the brand. It allows the bringing together of enterprises, while providing them with a common image and brand awareness among consumers.

The WIPO (World Intellectual Property Organisation) and the INTA (International Trade Mark Association) differentiate between two types of collective trademarks: ordinary collective marks, where members of a collective (a cooperative, association or organisation) share certain characteristics and certification marks which are based on defined standards, controlled by external certifying agencies, and open to anyone who meets these standards. ${ }^{7}$ Collective and certification marks are registered at national Trademark Offices and protect the proprietors from fraudulent use of the mark.

\footnotetext{
${ }^{4}$ Council Regulation (EEC) No. 2081/92 of 14 July 1992 and EU Regulation No 1151/2012 of 21 November 2012: http://ec.europa.eu/agriculture/quality/schemes/index_en.htm

${ }^{5}$ WIPO online document (p. 7): http://www.wipo.int/edocs/pubdocs/en/geographical/952/wipo_pub_952.pdf

${ }^{6}$ FAO online document: http://www.fao.org/fileadmin/user_upload/foodquality/fichefiles/en/c2.3.pdf

7 "The definition of mark includes a device, brand, name, word or label and a mark could be in any such form" (WIPO online document 2007). For the definitions of collective and certification marks cf. UNIDO document 2010.
} 
Place branding strategies for regions, as described below, use collective (umbrella) brands as communication and commercialisation tools, to 'sell' territories and baskets of typical products and services, based on unique territorial identities.

All those place-based marketing and branding initiatives give local private and public stakeholders, either individually or collectively, a unique position and visibility. This serves as basis to build a competitive advantage, both on a territorial and global scale.

\subsubsection{Regionalisation and decentralisation processes in Europe and Morocco}

From the 1960s onwards, one can observe processes of regionalisation and of vertical and horizontal rescaling in Western Europe (Brenner 2003). Vertical rescaling refers to a transfer of power from the nation-state to local institutions (downscaling, transfer of power to regions, cities etc.) as well as to higher, supra-national institutions (institutional upscaling, to the European Commission). Horizontal rescaling includes inter-organisational cooperation and coordination across territories and/or between state and non-state actors: something that is in general described as a 'shift from government to governance' (Brenner 2003, Stoker 1998). These processes oblige local authorities to take responsibility for territorial developments. They need to create suitable environments to stimulate economic growth, to support local enterprises and to ensure the welfare of the population. Hence, regions are facing strong national and international competition at an economic, spatial and identity level. This is reinforced by the globalisation, "exposing even the most remote spaces to competition and forcing firms, localities and regions to react and adjust to the new economic conditions" (Pike et al. 2006: 4).

The cohesion (or regional) policy of the European Union (EU) reflects the importance of the regional scale. Almost one third of the EU budget is spent on this policy, which aims to support the sustainable development of regions and reduce regional disparities. ${ }^{8}$ The European regional development policy emphasises the creation of economic advantages and territorial competitiveness via place-based approaches (EU 1999, 2011). Competitiveness has become the new paradigm for territorial development (Bristow 2010, Camagni 2002, Camagni \& Capello 2013). In line with this, many European regions have started to develop place marketing and branding strategies with the aim of increasing their attractiveness and competitiveness, creating

\footnotetext{
${ }^{8}$ http://ec.europa.eu/regional_policy/en/policy/what/investment-policy/
} 
dynamics and stimulating local development, by promoting their distinctive (material and immaterial) assets based on unique territorial identities.

Since the 1980s, after a period of strong centralisation, regions in France have progressively been given more administrative and financial autonomy (starting with the laws of decentralisation: Loi Deferre 1982 and 1983). Competences between state and regions are nowadays partly shared, and territorial projects are based on co-financing. In the framework of decentralisation, the number of French regions has currently been reduced from 22 to 14 (effective from 1 January 2016), to assimilate them with other European regions and strengthen their economic power.

In Morocco, regionalisation and decentralisation processes have been initiated since the 1970s and, strongly promoted by international development organisations, reinforced in 2010 by an 'advanced regionalisation plan'. This plan is supposed to lead to an integrative and sustainable development of the country as a whole. Territorial development will be reached via a valorisation of specific place-based assets, a participation of local actors and an increase of the attractiveness and competitiveness of the regions within a context of market liberalisation (Boujrouf \& Hassani 2008, El Ansari 2009, Haimoud online document 2012). Local resources and heritage then constitute key concepts for endogenous development and a driving force for public-private cooperation (El Ansari 2013). In this respect, typical local food products (produits de terroir) play an important role, exposing the influence of the French approaches to territory-based development and regulation (Fauvel \& Vanier 2006, Koop et al. 2010, Landel 2011), as part of new agricultural and rural development policies (Plan Maroc Vert).

In the context of changing geographical power distributions, there is an empirical need to know whether and how place brands may constitute a useful territorial governance and development tool, and a strategy for enhancing regional competitiveness - based on local resources, crosssector linkages and public-private interaction - in Europe as well as in Morocco.

\subsubsection{The Mediterranean area and its rich food heritage}

The diversity of small-scale producers, processors and distributors of food products in the Mediterranean area reflects the richness of the Mediterranean culture and its fascinating history. However, market liberalisation, with increased international trade and competition, puts pressure on the return of investment of agri-food SMEs, leading either to successful innovations or to 
bankruptcy, due to a lack of personnel or time for carrying out the required innovations. Furthermore, consumers tend to give up the traditional Mediterranean diet in favour of modern western industrial food (CIHEAM/FAO online document 2015, Padilla 2009), even though the Mediterranean diet is globally considered as extremely healthy (Belahsen \& Rguibi 2006, Maillot et al. 2011) and was even recognised in 2010 by UNESCO as an intangible part of cultural heritage. These tendencies may lead to a loss of cultural heritage and the biodiversity in Mediterranean food domains (FAO 2010, Rastoin 2009).

Until now, the focus has been on GIs, which are mainly developed as an institutional-driven tool for adding value to local food. As GIs have a strong socio-economic impact within the EU being most used largely in south European countries (especially in Italy and France) - they have also, for the last couple of years, been promoted in southern Mediterranean regions, and supported in Morocco by the national Plan Maroc Vert. However, the creation of GIs is not without its challenges in developing countries (Bramley 2011, Anders \& Caswell 2008, Fournier 2015, Chabrol et al. 2015). GIs deal with single product chains and do not address multiple products/services or a whole territorial system as place brands.

Hence, particularly in Mediterranean regions, where agriculture and tourism often constitute the most important sectors (Vandecandelaere \& Abis 2012), creating umbrella place brands as integrated territorial development strategies may offer new and better options for building synergies and creating dynamics. Here, the use of place branding strategies may be advantageous to farmers and local small (food and tourism) enterprises within a highly competitive economy, by commonly valorising and commercialising diverse typical products and services, based on a distinctive and recognisable territorial identity. This involves not only a strategy for adding value locally, but also for gaining a competitive regional advantage through differentiation (Porter 2000). Furthermore, place branding may also serve to protect the natural and cultural heritage of rural areas, to reinforce the embeddedness of local actors, to create or exploit local networks, and finally to stimulate the sustainable development of territories.

Therefore, it is relevant to assess options for developing umbrella place brands for jointly valorising, protecting and promoting all the endogenous assets of a place, supporting $a$ wide range of (small-scale) local actors and strengthening the rich food heritage. This is undertaken for the province of Chefchaouen in Morocco. 


\subsection{Theoretical context}

In order to understand the functioning and outcomes of place branding within the above described triple societal context (globalisation, regionalisation and decentralisation, and the gastronomic richness of rural Mediterranean areas), three established literature streams - in English and French - are mobilised and presented: (1) the principal stream draws on marketing and branding of places and their products/services; (2) the second makes use of regional studies; and (3) the latter incorporates elements from rural and food sociology. Hence, the (Anglo-Saxon) marketing and place branding perspective is combined with the (French) view on territories (as social constructs) and their development. These are enriched with a limited number of concepts from sociology that are relevant in a food and rural context. It is considered that insights from all three disciplines are needed for an understanding of the conditions, processes, dynamics and development outcomes of place branding in regions, since this is a complex and multidisciplinary phenomenon.

Multidisciplinarity is "the overarching methodological approach to place branding research" (Pasquinelli 2012: 131), as place branding involves multiple processes that can hardly be explained by one discipline alone. Indeed, "practitioners and academics involved in place branding should be prepared to scan horizons far wider than those associated purely with conventional brand management and brand strategy" (Dinnie 2004: 2). Therefore, this thesis also makes use of literature streams other than marketing and management, as regional studies and sociology - especially in the sense of interdisciplinarity, i.e. the interface between disciplines - in order to achieve a broader understanding of place branding processes.

\subsubsection{Place marketing and branding: origin, state-of-the-art in literature and critics}

According to the literature, the practice of place branding is not a recent phenomenon. In early history, there was some kind of 'hidden branding' (San Eugenio Vela 2013). Anholt (cited in Simms 2008) traces it back to Alexander the Great, who considered that the success of a territory depended largely on its image beyond its borders. The promotion of place identity seems to be 'almost as old as government itself' (Kavaratzis \& Ashworth 2005). Others see the historic origin of place branding in the $19^{\text {th }}$ century, where the struggle between places began, and the term 'city boosterism' emerged (Hankinson 2010). However, only since the beginning of the 1990s - in 
line with economic restructuring and increasing worldwide competition - a strategic marketing of places started in practice and began to be analysed in literature (Braun \& Zenker 2010).

While early academic research deals with the promotion and selling of places (Burgess 1982, Gold \& Ward 1994, Kearns \& Philo 1993), without establishing a clear link between the idea of promoting the image of places and the marketing discipline, from the 1990s onwards, a more structured concept of place marketing has been developed (Ashworth \& Voogd 1990, Kotler et al. 1993). Recently, the academic interest in place branding has increased considerably and the number of Anglo-Saxon contributions, in particular, has been growing (Braun \& Zenker 2010, Meyronin 2009, Moilanen \& Rainisto 2008). Many of the articles have been published in Place Branding and Public Diplomacy, the Journal of Brand Management and the Journal of Place Management and Development (for an overview cf. Gertner 2011).

However, according to Gertner (2011) and Andersson (2014), a major problem with the published literature is its fragmentation: articles often encompass disciplines other than marketing, business or management. Thus, place branding still remains peripheral in the marketing domain. This may be due to the fact that place branding sources encompass "many disciplines that rarely attract attention in the marketing literature" (Dinnie 2004: 1). The following main sources are put forward in literature (Dinnie 2004, Hankinson 2010, Kavaratzis 2005, Papadopoulos 2004):

- The country-of-origin (COO) literature that analyses the 'made-in' effect (buy-domestic) and product-country-images among consumers. There has been a lot of research since the 1960s on the relation between the product's origin and its effects on the consumers' perception and/or buying behaviour (for a literature overview cf. Dinnie 2004, Papadopoulos \& Heslop 2014, Verlegh \& Steenkamp 1999). COO has often been applied to agricultural products due to their intrinsic origin value. However, the $\mathrm{COO}$ concept does not incorporate a marketing or management strategy, such as place branding.

- Destination branding, dealing with tourist attraction to places (Cai 2002, Morgan et al. 2002). However, tourism constitutes only a part of an overall place branding strategy.

- Place development, as part of urban planning and linked to place management and governance (Ashworth \& Voogd 1990, Kotler et al. 1993).

- National identity, which describes identities linked to places, and is concerned with public relations (Smith 1991). 
Within the body of publications on place branding, certain relevant tendencies appear that are in line with the interest of this thesis. These are described in the following paragraphs.

Until now, a lot of attention has been given to nation branding (Anholt 2002, Dinnie 2008, Fan 2006, 2010) and to public diplomacy (Anholt 2006, Szondi 2010, Van Ham 2008). In addition, city branding has largely been treated in literature (Kalandides et al. 2011, Kavaratzis \& Ashworth 2005) as part of urban planning and economic development.

Place branding in regions, however, has been hitherto rather neglected (Andersson 2014, Zenker $\&$ Jacobsen 2015). Moreover, only a few studies have investigated the relation between regional branding, local cooperation and sustainable development. Examples are García et al. (2013), Messely et al. (2009) and Pasquinelli (2010), who discuss the capacity of regional branding to assist endogenous development. Their major conclusion is that - despite different contexts of place brands - a main common condition for place branding leading to endogenous development is the successful coordination and cooperation of different local stakeholder groups.

With regard to place branding in Africa, it has been stated that it is sparse, 'almost non-existent' (Osei \& Gbadamosi 2011). However, the potential and need for branding African countries has largely been recognised in literature (Anholt 2005, Freire 2014, Wanjiru 2006), and place branding has even been considered as a potential means to 'create a fairer distribution of the world's wealth' (Anholt 2005). Thus, focusing research on a case in Africa may seem highly appropriate.

Furthermore, despite the frequent usage of food and gastronomy in place branding as important parts of local culture and heritage, and as strong identity markers, knowledge of the role of food in strategic branding of places is limited (Berg \& Sevón 2014). Food has been considered as a sub-part of destination marketing and mainly been researched in relation to gastronomic tourism and the overall experience of visitors (Hall et al. 2003, Hjalager \& Richards 2003, Quan \& Wang 2004). In particular, up until now, there has been a lack of insight into the possibilities of place branding as an integrative strategy for adding value to local food products in the Mediterranean area

Finally, the measurement of the potential benefits and performances of place brands has become a key issue in the place branding domain (Florek \& Kavaratzis 2014: editorial for special issue on 'place brand equity', also Florek 2015, Zenker \& Braun 2015). Up until now, "there has hardly been any discussion on how (place) brand equity should be interpreted and how it should be 
measured" (Florek 2015: 230). This issue is even more important because place brands cause a lot of scepticism: not only do they often arise out of political decisions, but frequently considerable tax incomes are spent on place marketing activities (Jacobsen 2009). Hence, there is both a scientific and societal need to know if place brands really go beyond producing 'logos and slogans' by constituting a useful strategic tool either for local sustainable development, or for the management of places' reputational capital (O'Shaughnessy \& O'Shaughnessy 2000). In this context, it is important to note that cooperation and multiple stakeholder involvement are considered as key success factors of place branding, and have already received some research attention (Beckman \& Zenker 2012, Kavaratzis 2012, Pasquinelli 2013).

Regarding critical issues of place branding, one point is that although the concept has gained considerable attention in practice and theory over the past two decades, there is neither a common definition nor consensus of what place branding is (Bell \& Pike 2013, Zenker \& Jacobsen 2015). This is a problem, as research in this area lacks a clear conceptualisation and generic basis for scientific discussion. Anholt (2010: 1) considers that "it is difficult to see how a field of study or practice can mature unless some kind of consensus is reached on the definition of the field". Definitions vary and are partly derived from the marketing discipline (Table 1). While the first definition emphasises the psychological features and perceptions in consumers' minds, the others concentrate on the strategic usefulness of a brand from a place management and development perspective.

Table 1: Various definitions of place brand/branding

A place brand is a network of associations in the consumers' mind based on the visual, verbal, and behavioural expression of a place, which is embodied through the aims, communication, values, and the general culture of the place's stakeholders and the overall place design (Braun \& Zenker 2010: 5).

Place branding is the practice of applying brand strategy and other marketing techniques and disciplines to the economic, social, political and cultural developments of cities, regions and countries (Journal of Place Branding and Public Diplomacy).

Place branding can be considered as an effort to use strategies developed in the commercial sector to manage, if not necessarily wield, the soft power of a geographical location (Van Ham 2008: 127).

Place branding is the idea of discovering or creating some uniqueness, which differentiates one place from others in order to gain a competitive brand value (Ashworth 2009: 10).

A nation brand can be regarded as an umbrella brand that endorses many sector brands, for example, tourism, exports, investments, talent attraction, sports. (Dinnie 2004: 200) 
Another problem is a lack of theory development (Gertner 2011) and an incoherent vocabulary use in publications on place branding (Hanna \& Rowley 2008). In their recently published book Rethinking Place Branding (Kavaratzis et al. 2015), the editors note that:

\begin{abstract}
"The necessity for such rethinking has become increasingly apparent in the last few years in a need, felt by many, and not exclusively academic observers, for a more grounded, theoretical framework to what began and initially developed as a wholly practical activity. This need has become manifest in weaknesses in conceptual thinking and even a growing imprecision in terminology. Above all, and the most serious misgiving surrounding what remains a practical activity devised to achieve practical results, is the growing doubt that much official place branding is actually effective in attaining its often only vaguely delineated outcomes... The result of a few years of fevered activity around the world has been a mass of case examples, but few tools have been shaped for their comparative evaluation, assessment or synthesis allowing lessons to be learned that would be of value elsewhere." (242)
\end{abstract}

Furthermore, the predominantly qualitative or purely descriptive nature of research on this topic has also been critically regarded (Gertner 2011). There have been critics of the term 'place branding' itself from inside, made by Anholt (2008), changing it into 'competitive identity'. Finally, terms as destination, place, territory, etc., are not always used with a clear delimitation or definition of the geographic scale (Caldwell \& Freire 2004). As Hanna and Rowley (2008: 69) state, "the discipline of place branding is a new phenomenon that has yet to be fully investigated."

Hence, the literature review confirms the relevance of researching further the place branding concept, as well as place branding conditions and processes, leading to development outcomes in Mediterranean rural regions. In doing so, it is appropriate to consider place brands not only from a marketing perspective, but also in the context of regional development and sociology.

\title{
1.3.2. Regional studies
}

Due to globalisation, scientific and political interest in the regional geographical scale has resurged in the past decades, labelled as 'new regionalism' (Keating 1998).

In general, there is no consensus on what local and regional development exactly is. The underlying problem is that definitions and concepts change over time; they depend on specific places and on broader political and economic processes; and they are socially determined by groups (Pike et al. 2007, Storper 1997). Furthermore, different kinds of local development approaches exist, with different governance forms, which include various stakeholders and address various targets (Pike et al. 2007). The initial focus on economic development and growth 
has also broadened, so that it now includes political, social, cultural and environmental dimensions.

The definition of local development by the EC encompasses these sustainability aspects:

"Local development is intrinsically associated with a multi-dimensional concept of change bringing together economic, social, cultural and environmental dimensions; with innovation across and in the spaces between these dimensions. It may be seen as a method which helps improving quality of life, supporting or accelerating empowerment of ordinary people, developing or preserving local assets, overcoming market failures, strengthening cohesion, and defining and delivering grass-root development projects."

(EC 2010: 10)

Among the different approaches discussed in science and policy, the (French) territorial development paradigm is elaborated here, in line with the target research areas.

The French term territoire is polysemic, i.e. it refers to multiple meanings in the social sciences discourse. Territoire can be a spatial, social, cultural, economic or political(-administrative) concept (Fontanille 2014). Its English translation 'territory' is in general restricted to the designation of an inhabited and delimited space (Debarbieux 1999). This thesis follows the conceptualisation of territoire that underlies various French scholars (e.g. Pecqueur 2001, Leloup et al. 2005) "as a social construct, which results from a process of coordination of actors that come together to solve a problem, and of a construction of territorial resources that are activated (or identified) for renewing a territorial dynamic" (Hadjou 2009: 4, translated from the French).

The territorial development approach has appeared since the middle of the 1990s and takes into account not only a national, but worldwide competitive environment. It aims at making places more competitive and attractive. It introduces new forms of governance via a coordination and cooperation of multiple actors (also associations and the civil society), and includes top-down as well as bottom-up approaches (Baudelle et al. 2011, Campagne \& Pecqueur 2014). Territorial governance has been described as the production of rules by actors to regulate the economic, productive, social, etc., system (Angeon \& Houédété 2006). Local actors then socially construct their territory, in contrast to a given, historically-administrative, delimited geographical entity (Leloup 2005). According to Pecqueur (2013: 11), territorial development "may be defined as any process mobilising actors which leads to the creation of a strategy of adaptation to outside constraints, based on collective identification with a culture or a territory".

The territorial development approach thus emphasises the identification and valorisation of placespecific resources and identities that are different from their competitors (Côté 2003, Pecqueur 
2013). Territories, then, are considered as places with their own particular histories and identities. Heritage and local assets are used as elements for cooperation and as drivers for the construction and sustainable development of territories (Francois et al. 2006, Landel \& Senil 2009).

Territorial development is promoted by French development policies in the form of 'projets de territoire' - as transversal projects and strategies based on a territorial diagnostic, visions and competences, and elaborated by the local actors themselves. The territorial approach is also an interesting option for Maghreb countries, including Morocco (Koop et al. 2010). The objective to make territories more competitive and attractive, based on local resources, and integrate them into a global economy, is particularly important for Morocco as it has opened up its economy. Furthermore, a valorisation and promotion of local resources and identities seems to be adequate for the development of rural marginalised areas, as it takes into account local actors and their specific sociocultural and endogenous conditions.

\subsubsection{The sociology of local food, rural sociology and embeddedness}

Regional products have a long history, but their importance both from a supply and demand perspective has increased in recent decades, partly due to globalisation (Van Ittersum 2002). The need for producers to distinguish their products from those of competitors, through non-price factors (such as origin, perceived quality or image), has become urgent with a growing price competition (Kop et al. 2006). The consumer's perspective has largely been researched with the country-of-origin-effect (Iversen \& Hem 2008, Scarpa et al. 2005, Shimp et al. 1993, Verlegh \& Steenkamp 1999). Here, many authors explain consumer preferences for products of their home country with 'consumer ethnocentrism', emphasising a cognitive, economic side (Shimp \& Sharma 1987). On the other hand, consumers may also base their buying decisions on "a product's physical attributes, place of purchase or consumption and communicated heritage" (Tregear et al. 1998: 392) or on other, emotional associations (Von Alvensleben 2000). For example, terroir food products have a strong nostalgic value for consumers (Aurier et al. 2005).

Local food products are also embedded in 'alternative food networks' and agricultural rural development debates on sustainability and re-territorialisation, being considered as ways to create value locally, and preserve traditional and small-scale farming, and thereby contribute to the protection of communities and landscapes, as well as to rural development (Goodman 2004, Horlings \& Marsden 2014, Tregear 2011, Venn et al. 2006). Dessein (2015) considers food as a 
driver of 'strong territorialisation', which is described as a combination of neo-endogenous development and co-production between society and environment. A strategy of 'reconnecting' agricultural practices to place can also include new relations between urban and rural areas and new producer-consumer interfaces (Horlings \& Marsden 2014). The valorisation of rural assets, including food, is central in the endogenous rural development approach, which is considered as a development 'from within' and increasing the autonomy and self-efficacy of rural areas. More recently, the term neo-endogenous development has been introduced. It describes the act of balancing endogenous resources or local control and exogenous global forces for reducing the vulnerability and exchangeability of rural areas (Ray 2006). Thereby, rural resources allow developing new types of marketing strategies based on distinctive regional identities that result in externally-derived added value (Horlings \& Marsden 2014). However, the link between adding value to local resources based on strategic place branding in the context of rural development is not yet firmly established in literature, but is explored here.

Another sociological concept relevant for this thesis is embeddedness. It is central to economic sociology and describes the extent to which economic activities depend on their non-economic context. In the original sense developed by Polanyi and Maciver (1957), embeddedness considers the economy as related to a social, cultural and institutional context (societal embeddedness). The authors emphasise the historical pathways of economic actors and give embedding an evolutionary character. While Polanyi and Maciver do not connect the concept directly to social networks, the seminal work on embeddedness by Granovetter (1985) describes relations between individuals or firms as embedded in social networks (structural embeddedness). Both ideas disapprove neoclassical economic thoughts which under-socialise economic behaviour and postulate a dominance of pure market forces. A third dimension of embeddedness, which emerged in line with the new regionalism from the beginning of the 1990s, is linked to a geographical or spatial aspect, considering the extent of an economic actor's anchorage in a particular place (territorial embeddedness; cf. Hess 2004).

\subsubsection{Conceptual diagram: linking marketing, regional studies and sociology}

The use of the three different outlined academic fields is motivated by the complexity and interrelation of current economic, political and social challenges inherent in place branding, as stated in the societal context. To understand the rich and complex phenomenon place branding in 
(rural) regions, it is important to complement a strategic marketing and branding perspective with regional development and sociological concepts. Furthermore, one can state that for each of these literature streams, a considerable body of literature already exists. However, it is the combination of the three that makes this thesis approach to place branding original.

The combination of literature leads to three units of analysis: (1) the first deals with the place branding phenomenon in a narrow sense, seeking to clarify the concept and understanding it as marketing and branding strategy for the development of regions and their specific (material and immaterial) assets, based on a distinctive territorial identity; (2) the second considers the historically evolving regional context, i.e. territorial development policies and public-private interactions (territorial governance); and (3) the third analyses place-based, collective and embedded activities among various local actors, taking into account various forms of cooperation and diverse identities. The latter two are the conditions that make the marketing tool work in a specific way, and are needed for fully understanding the functioning of the place brand that contributes to territorial development.

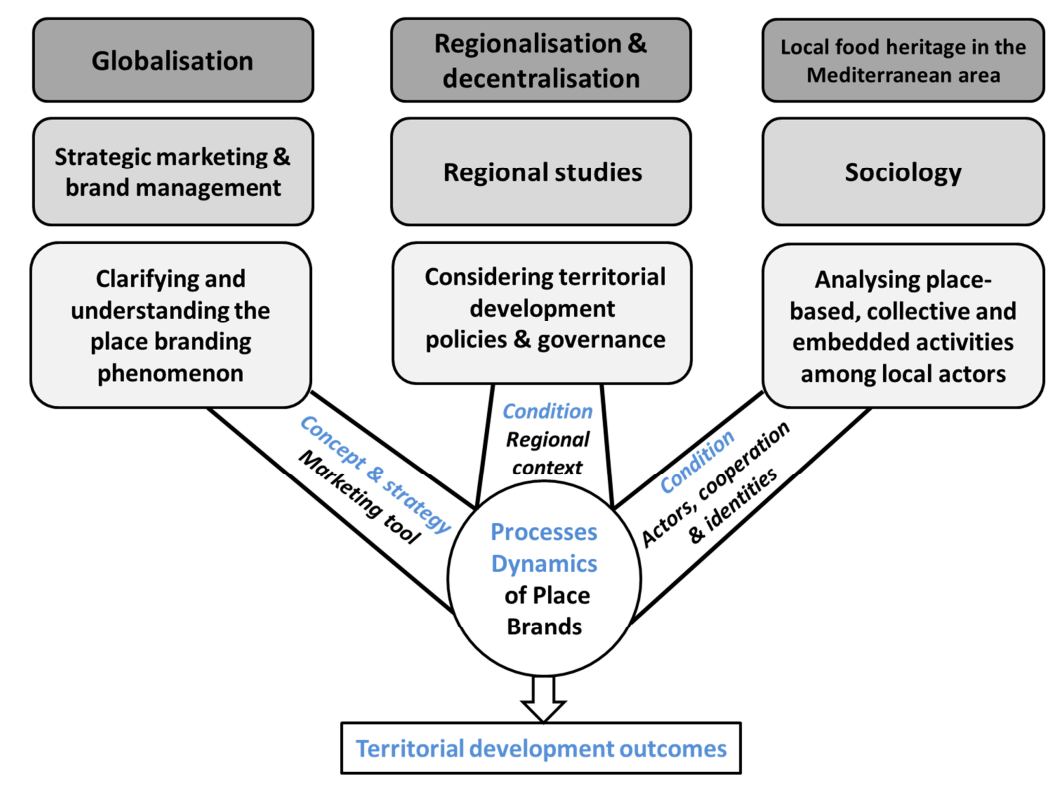

Figure 1: Conceptual diagram

Consistently, the following research objectives and questions are linked to this conceptual scheme, and the case study and interdisciplinary-oriented research approach aimed at the exploration of an emerging phenomenon fits into this multiple perspective, too. 


\subsection{Objectives and research questions}

The purpose of this research is twofold: to contribute to the scientific debate and emerging academic field of place branding; and - drawing on literature domains of place branding and marketing management, regional studies and sociology - to understand how place brands evolve, function and create beneficial outcomes relating to agribusiness and territorial development. This leads to three objectives.

The first objective is to shed light on different types of place brands, because no consensus has yet been reached in theory on what place branding exactly is.

The second objective is to understand the (enabling or constraining) conditions, processes and dynamics of place branding in regions, leading to territorial development outcomes.

The third objective is to gain insights into the concept of place brand value - i.e. into the kind of beneficial outcomes that place brands can create for various actors within a territory - including possibilities for their assessment.

The main research question of this thesis is formulated as follows:

What are the underlying conditions, processes and dynamics that explain how place branding contributes to territorial development?

Sub-research questions are the following:

1. How does a place brand arise and lead to beneficial outcomes, and for whom? How can place brand value be systematically captured and monitored, and in what way is value creation impacted by internal and external conditions? (Chapters 2 and 3)

2. What are generic aspects and particularities of place brands? How and why do place brands differ with regard to their origin, management and development? In what way does embeddedness play a role within regional branding processes? (Chapter 4)

3. What are the enabling and constraining conditions for developing a place brand as a collective and cross-sector strategy for territorial development in Chefchaouen, Morocco, and why? (Chapter 5) 
In order to answer these questions, and to link the thesis chapters, three aspects are simultaneously treated. The first is about marketing and more precisely, about the strategic branding of regions and their specific local assets based on distinctive identities (with a focus on food products and tourism); the second deals with local (i.e. territorial, rural and agribusiness) development and public-private collaboration (territorial governance); and the third concerns place-based, collective and embedded activities in the food and tourism sectors (similar to the mono-product collective approaches of GIs). Hence, all the chapters raise the question about what kind of tools place brands in regions are, under what conditions, processes and dynamics they emerge and work, and what kind of benefits they can create, for whom and how.

The approach to the research questions is explained in the next section concerning the methodology.

\subsection{Methodology}

\subsubsection{Choice of the research areas}

The main research area is the Mediterranean basin with a focus on the region LanguedocRoussillon in South-France and the province Chefchaouen, which is situated in the Rif Mountains, North of Morocco (Figure 2, p. 22). A view on both sides of the Mediterranean Sea is interesting, as Mediterranean countries possess similar territorial (gastronomic, cultural and natural) assets and climatic conditions; their nutrition habits are similar; and they trade agricultural products between themselves. However, they are embedded in different political and economic contexts.

Major reasons for the choice of French and Moroccan regions are as follows.

France has a long tradition and rich experience regarding the valorisation and commercialisation of local food products (produits de terroir). The INAO (Institut National de la Qualité et de l'Origine) is the oldest institute for legal food protection in Europe. France has the highest sales value of products with GIs, and French retailers such as Carrefour and Leclerc have, for more than a decade, used their own brands for local food, such as Reflets de France and Nos régions ont $d u$ talent. For the region Languedoc-Roussillon, agriculture and tourism are major economic sectors. It is the world's largest wine producing area and many small farmers and food processing enterprises are settled in the region. Since 2006, Languedoc-Roussillon has had an umbrella place 
brand called Sud de France, which is mainly used to valorise and promote local wines, food products and tourism services at a local as well as an international level.

Morocco has been chosen because of its increasing international cooperation and opening-up of the economy (e.g. the EU-Moroccan 2012 Free Trade Agreement for agricultural products), its decentralisation and regionalisation process (Plan de Régionalisation Avancée) and its recent initiatives for the development of the agricultural and tourism sectors (Plan Maroc Vert and Vision 2020), which represent strategic sectors for the socio-economic development of the country. ${ }^{9}$ The province Chefchaouen belongs to the region Tanger-Tétouan, which has been defined as one of the strategic regions for the development of the agricultural sector. The target area Chefchaouen has a rich gastronomic heritage and attained the UNESCO label in 2010, being one of the emblematic communities for the healthy and traditional Mediterranean Diet. Furthermore, the province has a rich biodiversity, including two national parks in the surroundings (Park Talassemtane and Park Bouhachem). The city Chefchaouen possesses several cultural assets, such as the ancient medina and the Kasbah, and has a mainly positive image as a calm and pleasant place. Due to these unique characteristics, it has already become a popular tourist destination. Many initiatives are taken to valorise and promote the various local assets. Therefore, Chefchaouen offers good options for developing an umbrella place brand based on the food and tourism sectors.

The interest for both target areas was driven by the question of whether place branding constitutes or could constitute an innovative and integrative territorial marketing strategy to add value to local food products and tourism services by building cross-sector synergies, and to strengthen the competitiveness of rural regions and their small economic actors, leading to sustainable development outcomes. The originality of this research is that it investigates the possibility of creating a place brand for territorial (and agribusiness) development in a new context of a developing country, building on its own preliminary findings gathered from studies on existing regional brands in France and Europe.

\footnotetext{
${ }^{9}$ Agriculture in Morocco constitutes $19 \%$ of the national GDP (15\% agriculture and 4\% agri-food) and has an employment rate of about $43 \%$ of the total workforce; the tourism sector contributes with $12 \%$ to the national GDP and has $5 \%$ of the workforce. Cf. http://data.un.org/CountryProfile.aspx?crName=MOROCCO.
} 


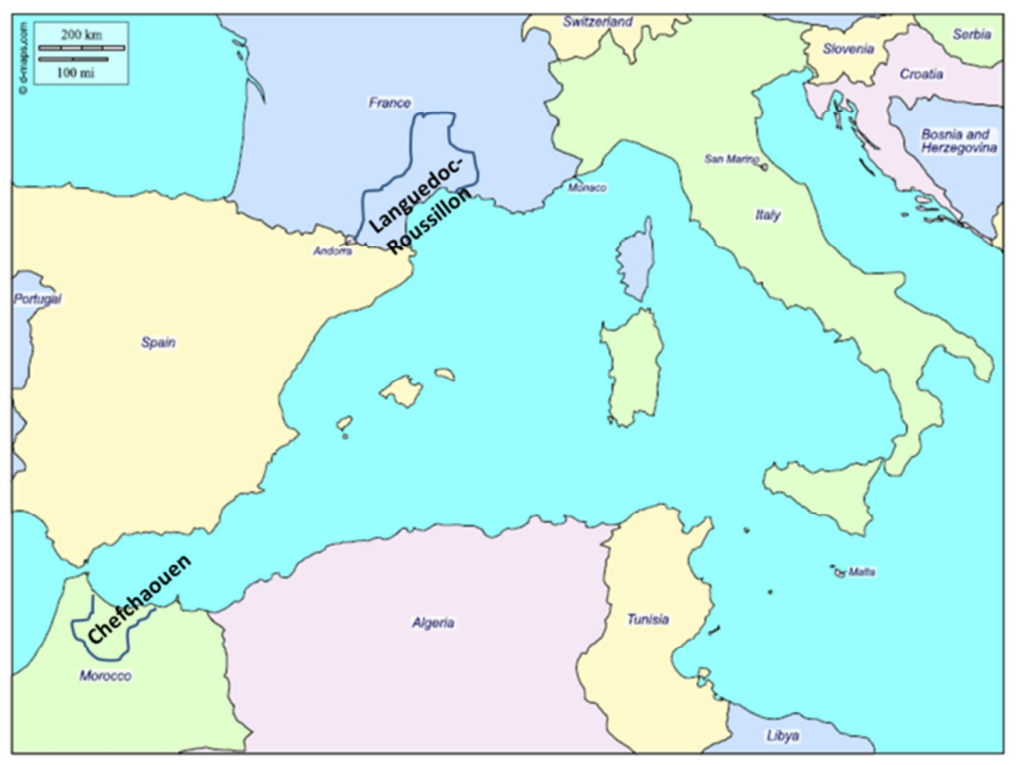

Figure 2: Locations of the main research areas

\subsubsection{Case study design}

The case study was chosen as a research strategy, and this has been defined as "an intensive study of a single unit - a spatially bounded phenomenon - for the purpose of understanding a larger class of (similar) units" (Gerring 2004: 341). The appropriate unit of analysis (the case) can best be determined in relation to the initial research questions (Yin 1994). According to Yin (1994: 1), case studies are 'the preferred strategy when 'how' and 'why' questions are being posed, when the investigator has little control over events, or when the focus is on a contemporary phenomenon within some real-life context." Therefore, the case study is adequate for exploring, understanding or explaining an event, process, decision or intervention which is still unknown and not well researched. In this sense, the case study is ideal with regard to the purpose of this thesis, i.e. to understand current place branding processes in their specific contexts. Other characteristics of case studies include the fact that they rely on multiple sources of evidence (with data that needs to be converged by triangulation), they can benefit from previous theoretical propositions, and they are not necessarily based on qualitative, but can also include or even consist of quantitative evidence. 
Among the types of case studies, one can differentiate - depending on the purpose of the research, which can be descriptive, explanatory or exploratory - between a single case study, a multiple case study and a single case study with embedded units (Yin 2003). In this thesis, the three different types of cases studies are undertaken. The advantages and limitations of such a multiple research approach are discussed in Chapter 6.

Table 2: Purposes and types of case studies and their application in this thesis

\begin{tabular}{|c|c|c|}
\hline Case Study Type & Research purpose & Application in this thesis \\
\hline Descriptive & $\begin{array}{l}\text { This type of case study is used to describe an } \\
\text { intervention or phenomenon and the real-life } \\
\text { context in which it occurred. }\end{array}$ & $\begin{array}{l}\text { Used to describe the case of the Sud de } \\
\text { France brand as public intervention to } \\
\text { support regional key sectors (Chapter 2) }\end{array}$ \\
\hline Explanatory & $\begin{array}{l}\text { This type of case study would be used if you were } \\
\text { seeking to answer a question that sought to } \\
\text { explain the presumed causal links in real-life } \\
\text { interventions that are too complex for the survey } \\
\text { or experimental strategies. }\end{array}$ & $\begin{array}{l}\text { Used to understand links between } \\
\text { complex processes, conditions and } \\
\text { outcomes of four European regional } \\
\text { branding cases (Chapter } 4 \text { ) }\end{array}$ \\
\hline Exploratory & $\begin{array}{l}\text { This type of case study is used to explore those } \\
\text { situations in which the intervention being } \\
\text { evaluated has no clear, single set of outcomes. }\end{array}$ & $\begin{array}{l}\text { Used to explore the various outcomes of } \\
\text { the Sud de France brand (Chapter 3) } \\
\text { Used to explore different initiatives for } \\
\text { valorising local resources and their } \\
\text { outcomes in Chefchaouen (Chapter 5) }\end{array}$ \\
\hline Single-case study & $\begin{array}{l}\text { A single-case study is appropriate under several } \\
\text { circumstances, e.g. if it is a critical case in testing } \\
\text { a well-formulated theory, an extreme or unique } \\
\text { case being worth to be documented, or a } \\
\text { revelatory case, i.e. a phenomenon previously } \\
\text { inaccessible for scientific investigation. }\end{array}$ & $\begin{array}{l}\text { The Sud de France case is considered as } \\
\text { interesting and revelatory: it has not yet } \\
\text { been researched (Chapters } 2 \text { and } 3 \text { ) }\end{array}$ \\
\hline $\begin{array}{l}\text { Multiple-case } \\
\text { studies }\end{array}$ & $\begin{array}{l}\text { A multiple-case study enables the researcher to } \\
\text { explore differences within and between cases. } \\
\text { The goal is to replicate findings across cases. } \\
\text { Because comparisons will be drawn, it is } \\
\text { imperative that the cases are chosen carefully so } \\
\text { that the researcher can predict similar results } \\
\text { across cases, or predict contrasting results based } \\
\text { on a theory. }\end{array}$ & $\begin{array}{l}\text { The analysis and comparison of four } \\
\text { different European cases (Chapter } 4 \text { ) } \\
\text { allows understanding generic aspects } \\
\text { and differences regarding brand } \\
\text { management, processes, contextual } \\
\text { factors and outcomes of place branding } \\
\text { initiatives }\end{array}$ \\
\hline $\begin{array}{l}\text { Single case study } \\
\text { with embedded } \\
\text { units }\end{array}$ & $\begin{array}{l}\text { The ability to look at subunits that are situated } \\
\text { within a larger case is powerful when you } \\
\text { consider that data can be analysed within the } \\
\text { subunits separately (within case analysis), } \\
\text { between the different subunits (between case } \\
\text { analysis), or across all of the subunits (cross-case } \\
\text { analysis). The ability to engage in such rich } \\
\text { analysis serves to better illuminate the case. }\end{array}$ & $\begin{array}{l}\text { The Chefchaouen case does not yet } \\
\text { constitute one consistent place branding } \\
\text { initiative, therefore diverse subunits are } \\
\text { explored (Chapter 5) }\end{array}$ \\
\hline
\end{tabular}

Source: based on Yin (2003) 


\subsubsection{Data collection and analysis}

Research data for the cases was collected (1) via field trips and visits (Languedoc-Roussillon: the brand evolution was directly over five years; Morocco: three main field trips); (2) via direct observations in the field; (3) via documentary research, including print and online (regional, national and international) policy documents, reports and articles, often in their original language; and (4) via in-depth interviews with key informants (total $n=52$; Morocco $=28$; LanguedocRoussillon $=20$; Black Forest $=4$ ) during the period between November 2012 and June 2015. In addition, an online survey was conducted among residents and consumers within the LanguedocRoussillon area $(\mathrm{n}=207)$ in order to investigate the perceived value and benefits of the Sud de France brand.

Written and oral data was summarised and interpreted according to matching themes, using content analysis (Berg 2009). Main themes - consistent with the analytical units - concerned: the place brand origin, evolution and management (the marketing strategy), the regional and institutional contexts, as well as the type of partnerships and cooperation (the conditions, processes and dynamics), and the members' motivations for place brand adherence and their perceptions (or expectations) of place brand value and effects (the outcomes). Furthermore, process tracing was conducted, event histories composed, documents analysed, and perspectives of different public and private stakeholders compared.

The precise way of data collection and analysis is explained more in detail in each chapter.

\subsection{Thesis outline}

This thesis has arisen from an interest in, and from a further research need for, the rich and complex phenomenon called 'place branding'. It investigates the various conditions, processes and dynamics of place branding in regions, leading to territorial development outcomes. It therefore focuses on place branding strategies for local food products and tourism services in rural regions in Europe and Morocco, questioning the collective processes and governance forms of the place brands, the types of value creation as well as the determining conditions for place branding outcomes. 
The introduction (Chapter 1) has presented the context and relevance of the project from a societal and scientific perspective. It has described and argued the literature that has been mobilised, including place marketing and branding, regional studies and sociology. It has also presented the main objectives and research questions. Finally, it has explained the methodology used and provided a short overview over the structure and content of the thesis.

Chapter 2 is an in-depth case study of the place brand Sud de France, belonging to the region Languedoc-Roussillon, and mainly used for the valorisation and promotion of local wine, food and tourism, but also serving institutional aims. It is a study of local dynamics and the process of place branding, leading to beneficial outcomes of a public development intervention. It seeks to understand the context and process of a place brand and the kind of benefits created by tracing the history and development of Sud de France, and by exploring the various economic and noneconomic effects of the brand among local actors via semi-structured interviews.

Chapter 3 is a continuation and a deepening of Chapter 2, as it further investigates the kind of value that can be created by a place brand, and for whom, using the Sud de France case. Based on stakeholder and brand equity theory, it develops, stepwise, a measurement model and monitoring tool for the value of place brands. In doing so, it first identifies key internal place brand stakeholders, including local governments, enterprises, residents and consumers, and thereafter establishes a set of indicators of place brand value which correspond to the perceived or expected brand benefits for these stakeholders. The measurement model for place brand value is empirically tested with the brand Sud de France, via a survey among residents and consumers.

Chapter 4 offers a multiple and comparative analysis of four different regional branding cases in Europe, with the aim to ascertain if the Sud de France case can be considered as representative of how place branding processes take place. Therefore, it seeks to gain insights into the generic aspects and particularities of place brands and into the general conditions and context-dependent factors for successfully developing and maintaining them. It combines a marketing perspective with food sociology and rural development, and researches strategic and operational brand management issues, as well as various conditions, such as public policies, cooperation and governance forms, territorial identity and the anchorage of local actors in a place. It also contributes to a further understanding of the variety of development outcomes that can be created by place brands. 
Chapter 5 comprises an in-depth explorative case study of place branding options in the province of Chefchaouen, Morocco. This chapter has three aims: first, to gain insights into the processes, dynamics and conditions for successfully developing a place brand in an Moroccan context; second, to understand whether, and to what extent, a European concept could work in this context; and third, to confront a constructing case with existing cases. In order to do this, the cooperating processes and determining factors for creating a place brand as coherent and collective territorial development project in Chefchaouen are researched. The preconditions and various initiatives towards place branding are analysed at three action levels: macro, meso and micro. Specific attention is given to the issues of local cooperation and network activities, to leadership and political unity at the meso-level, which are strongly related to the question of territorial governance.

Chapter 6, the final chapter, highlights the main results gained from this thesis and discusses the conclusions drawn from the results. It also considers the implications of the research for the place branding concept, for theory building, and for methodological approaches, as well as for development policies and place brand management. Finally, it makes suggestions for further research.

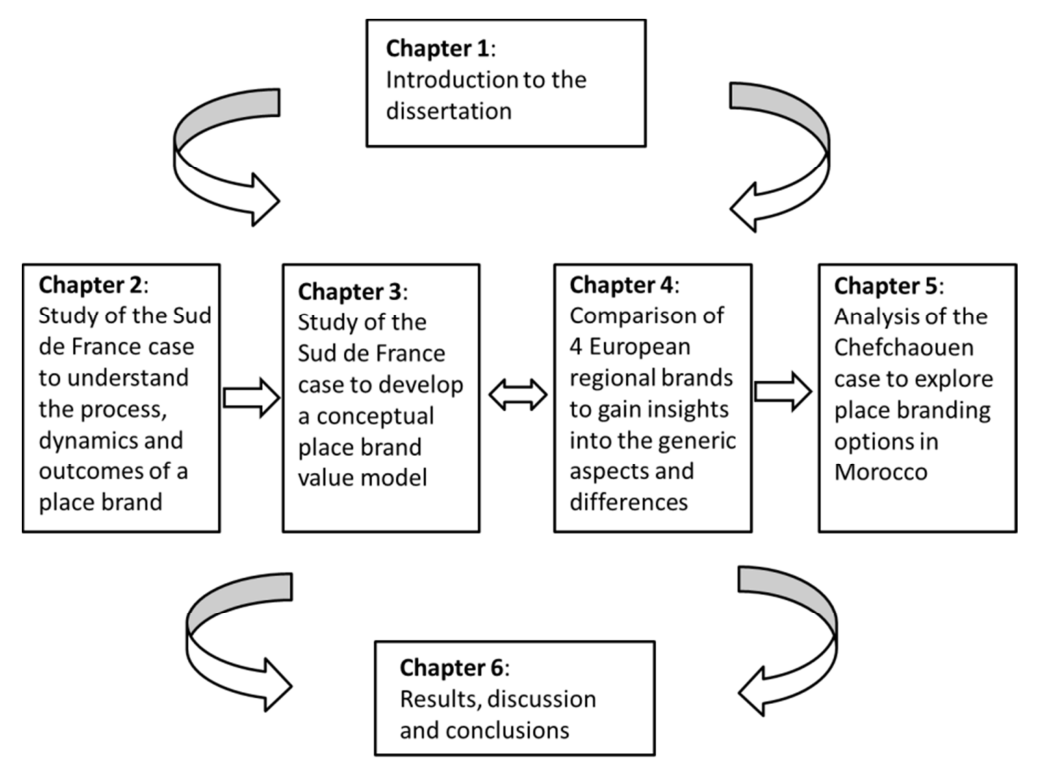

Figure 3: Thesis outline 


\section{CHAPTER 2}

How to capture place brand equity? The case of Sud de France

Donner, M., F. Fort and S. Vellema (2014) How to capture place brand equity? The case of Sud de France. Place Branding and Public Diplomacy 10 (2) pp. 145-157 


\section{Chapter 2}

\section{How to capture place brand equity? The case of Sud de France}

\section{Summary}

Within a globalised and highly competitive economy, the development of place brands has become important for cities, regions and countries. However, there is still little evidence about the conceptualisation and measurement of their performance. In order to contribute to the current discussion of place brand equity, we analyse the effects of a branding initiative in the South of France. According to the collective aspects of the place brand concept, we propose a multidimensional approach through qualitative interviews with various stakeholders and a review of secondary, mainly statistical data. Findings indicate that several factors are crucial for capturing equity of place brands. First, their collective character, involving different stakeholders, second, the fact that they generate economic and non-economic outcomes, third, their dependence on a socio-political and macro-economic context and fourth, the time they need to establish. All these constituents require a more holistic approach to capture place brand equity than usual brand equity definitions for companies. Results also suggest that if place brands aim at long-term development of places, estimating their overall value can be based on evaluation logics for public development interventions, which are easily feasible, time and cost saving and fulfil the need for accountability for governmental institutions. 


\subsection{Introduction}

Brand equity aims to define the value of a brand. As brands are intangible assets, one deals with a complex issue and faces a diversity of definitions and measurement methods in marketing literature as well as from practical accounting side (Kapferer 2008, Wood 2000).

Traditional academic approaches to brand equity build on either product-consumer relations (Aaker 1996, Keller 1993) or concentrate on financial impacts of a brand on the performance of individual companies (Simon \& Sullivan 1993). The consumer-oriented definition of brand equity can be sub-divided into two perspectives. The first one measures mental brand equity, i.e. the impact of the brand on the consumers' consciousness (brand associations, awareness and perceived quality). The second one investigates the consumers' behavioural response to the brand (loyalty, purchase intention, commitment). On the contrary, a company-based approach analyses the added value to a firm in terms of money and draws on financial and economic indicators such as profit, turnover, cost-benefit ratio and market share as effects of branding. More recent approaches, mainly coming from business-to-business or services marketing, focus on brand equity achieved through consumer or customer relationships (Berry 2000, De Chernatony \& Segal-Horn 2003, Grönroos 2001).

Kapferer (2008) points out that many practices of brand equity measurement only use one or two of the above sets of indicators (e.g. brand awareness, or loyalty, or market share). They don't take into account other important aspects, such as the time factor (evolution of brands), competitors, marketing-mix, possibilities of brand or geographical extensions etc. Apart from these shortcomings, another critical point is that different methods may relatively well determine the brand value of individual companies, but may be largely insufficient to measure brand equity for places. We argue that place brands require different assessment approaches and other performance measurements than company brands.

This article is based on a case study of the brand Sud de France in the region LanguedocRoussillon (South of France) and focuses on the evaluation of place brand equity in relation to the regional branding strategy. We outline the theoretical background and methodology. Then the case study is presented, followed by analysis and discussion. 


\subsection{Theoretical background}

It has been highlighted in place brand literature that place brands are complex and difficult to control (Braun \& Zenker 2010, Kavaratzis 2005, Moilanen \& Rainisto 2008). Several reasons are put forward in literature. First, place brands involve different public and private partners and aim at diverse target groups. Therefore, neither a dyadic product-consumer nor a company-customer perspective seems to be sufficiently elucidative. An assessment of place brand equity rather should take into account effects on different stakeholder groups. Stakeholders are defined as "any group or individual who is affected by or can affect the achievement of an organisation's objectives" (Freeman 1984: 46). Stakeholder theory is based on the assumption that a firm's performance not only depends on direct business relationships, but also on relations with a wide range of people and organisations, such as media, NGOs, the public opinion or even competitors. Studies of multi-stakeholder processes (Hankinson 2004, Morgan et al. 2003) suggest that success is achieved by the involvement of various stakeholder groups acting within a spatially bounded area. Until now, literature dealing with 'country equity' has focused on country images and perceptions by the consumer, explaining consumer preferences for products of their own or another specific country (Dinnie 2004, Papadopoulos \& Heslop 2002, Verlegh \& Steenkamp 1999). A second reason for the unpredictable outcomes of place brands is that these are umbrella brands (Iversen \& Hem 2008). They can cover a wide range of tangible and intangible assets, such as natural and cultural sites, local products and tourism services. Umbrella brands also give options for brand extensions. This generally may lead to multiple and different outcomes and interpretations. In his stakeholder-brand value model, (Jones 2005) shows that outcomes of a brand cannot be conceived by one single criterion or measure, as they are of quite different nature. He lists possible outcomes in addition to profitability, such as reputation, synergy or political influence. A third reason is related to functions of place brands as policy instruments (Anholt 2008, Van Ham 2008). They can be used to manage place identity and reputation and as communicators for lifestyles, norms and values (Van Ham 2008). They may also serve as strategic tools for local development of places, attracting tourists, companies and skilled people, or enhancing export opportunities for local firms. Therefore, a measurement of place brand equity should bear in mind the socio-cultural, economic and political context of a place. Its characteristics influence its general competitiveness as well as the management and outcomes of a branding initiative (Kotler \& Gertner 2002, Rainisto 2003). Fourth, place brands adopt a broader perspective and longer time horizon than single companies' brands. Although both seek 
to achieve competitive advantages and value increase, place brands particularly aim to encourage long-term development processes of places. This may include the creation and maintenance of local employment, or the protection and valorisation of intangible assets, i.e. historical, cultural or natural assets. Place brands are expected to offer an opportunity to "contribute above and beyond that tired old litany of 'increasing shareholder value'... to create a fairer distribution of the world's wealth" (Anholt 2004: 17). Finally, it could be noted that place brands are often used by firms in association with other collective or individual brands.

These reasons motivated us to use an in-depth case study and to propose a multi-dimensional approach that addresses the complexity of place brand equity. The relevance of this attempt was also confirmed by policy makers and place managers. Chantal Passat, responsible for the agrifood sector of Sud de France Development - an organisation which coordinates all activities related to the brand Sud de France - stated in an interview that:

"The regional government continuously asks me about the economic impact of Sud de France on local food enterprises. But I don't have indicators, and enterprises are too busy to analyse their internal sales figures while differentiating between collective brand, own brand, or no brand... So what I really need to know is how to measure the value of this brand." (Interview 14 June 2013)

By analysing the effects of the Sud de France branding strategy, we aim to contribute to the current discussion of place brand equity and to review the assumptions above. This case study allows gathering and sharing new insights about possible outcomes and working mechanisms of place brands as well as propositions for their evaluation.

\subsection{Methodology}

For the Sud de France case, we propose to evaluate place brand equity by analysing various effects of the regional brand on different stakeholder groups and the place as a whole. As place brands are usually initiated by the public sector, we seek to answer three questions which normally are used to evaluate development intervention impacts (Ton 2012, Ton et al. 2011):

- Does it work? What positive and negative effects/changes does the place brand generate for regional stakeholders?

- How does it work? What mechanisms of the brand generate intended or unintended effects, for whom, and under which conditions?

- Will it work elsewhere? What elements might work for whom under which conditions? 
We offer a multi-dimensional approach to place brand equity through evaluations by various stakeholders on the one hand and a review and an analysis of secondary, mainly statistical data on the other hand. Thirteen semi-structured interviews documented the various perceptions and expectations of public and private actors within the regional system. The interviews were triangulated with secondary data, i.e. press and academic articles, internet sites and policy documents. The case study reflects individual opinions as well as broader developments taking place through and in the context of the branding initiative. In order to highlight the background, we briefly present the origin, objectives and strategy of the brand, then identify the main stakeholders involved and finally analyse the brand effects.

This allows gaining new insights about the effects and working mechanisms of place brands including information about their potential and limitations - and propositions for an overall evaluation.

\subsection{Main results: the Sud de France case}

Languedoc-Roussillon is one of the 27 regions in France, situated in the South and bordered by the Mediterranean Sea, with Montpellier as capital. Geography and culture within this region are highly contrasting, and its economy is still the lowest of all French metropolitan regions, with a high percentage of unemployment (13,5\% in 2012). Two key economic sectors are tourism and agriculture; Languedoc-Roussillon is the world's largest wine producing region. Compared to other regions in the Midi like Provence or Côte d'Azur, Languedoc-Roussillon remained relatively unknown for a long time, despite its beautiful landscapes, cultural heritage (such as the Pont du Gard or the medieval city of Carcassonne), hundreds of kilometres of coast and enormous wine production.

\subsubsection{Origin, objectives and strategy of the brand}

The former president of the region, Georges Frêche (2004-2010), wished to create a common regional identity, to bring the region out of its seclusion, to activate resources for internationalisation and to participate in major economic markets. So, he initiated a collective territorial brand called Septimanie, inspired by the historical name of the area during the period of the Visigoths. But Septimanie was a flop, facing vehement resistance from the Catalonian part of 
the region, who saw this name as damaging their identity (Molenat online document 2005). After this failure, Sud de France was launched in 2006. The intention of this brand name was to evoke positive associations with French cuisine in general, with the sun and the South - already renowned abroad because of Provence and the Côte d'Azur - in particular. It was initiated in a time of economic crises where especially small firms had difficulties to expand. Even though Sud de France was firstly intended to be a common export label for wine companies, it was immediately extended to other agri-food chains and in 2008 to tourism services.

Since its beginning, the marketing strategy focused strongly on international export of local products, mostly wine, as well as on promotion of the region in general, supported by large advertisement campaigns financed by the regional government (about 15-18 million Euros yearly, Manceau online document 2010 ${ }^{10}$. The promoted image is constructed upon values of the Mediterranean art of living, as an expression of a convivial lifestyle, with authentic, diverse, tasty, healthy food and wine. The image combines tradition with modernity.

Entrance criteria for using the brand are defined in different catalogues of specifications, depending on category (wine, food or tourism services). Contrary to tourism, where high quality is demanded and controlled via an external audit, the access for food producers has until now not been very strict. After several problems concerning food provenance and quality - e.g. products originating from Spain were sold under the Sud de France label - the quality book was re-edited in 2013 in order to achieve a higher level of specifications. This repositioning was done with caution, as it may lead to an exclusion of small producers or companies (Interview C. Passat, 14 June 2013). Using the brand doesn't offer a direct price premium for producers - as French foodstuffs are already highly priced and therefore less competitive at international level - but other advantages, as presented below in the interviews.

In 2013, the umbrella brand brought 7,800 different agricultural products and 774 quality tourism services under its banner, from more than 2,600 members (varying from wine and food producers, food enterprises, hotels, restaurants, to local tourist offices). In addition, Sud de France is also used as an institutional brand, associated with, amongst others, sport and cultural events, the universities of Montpellier and Perpignan or the Sète harbour.

\footnotetext{
${ }^{10}$ This is not an official figure from the regional government, who was not willing to communicate the exact amount.
} 


\subsubsection{Governance structure and stakeholders involved}

As brand owner, the regional government (La Région Languedoc Roussillon) plays a directive role in the implementation of the brand. It finances and governs the brand, and gives licenses to its users. All Sud de France related activities of different private users from the wine, food and tourism sectors are coordinated by Sud de France Development. This organisation defines collective strategies for distribution, export and business development, ensures the worldwide promotion by special Sud de France Festivals and assists the enterprises in their internationalisation. It also plays a strategic role as interface between producers and buyers, principally large retail groups. In addition, Sud de France Development is responsible for the international stores: Les Maisons de la Région. These stores are situated in Shanghai, London, Casablanca and New York, providing among others commercial and logistic support to exporting enterprises in key markets. However, the name of these stores doesn't follow the Sud de France logic, as their objectives go further than the scope of the brand; i.e. they also aim at attracting foreign investment, based on other assets such as logistics, tax reductions or research activities. Sud de France Development is financed by the regional government and supported by other public institutes, such as the regional Chamber of Commerce and Industry (CCI), the association of the agri-food industry LRIA (Languedoc-Roussillon Industries Agro-Alimentaires), or Invest Sud de France. ${ }^{11}$

Main private stakeholders are wine producers and farmers, food production companies and tourism service providers. As the agri-food sector of the region principally consists of small and very small producers and firms, cooperatives and inter-professional organisations constitute significant representatives. The big national retail groups such as Casino, Carrefour or Auchan also play an important role for the brand with their regular promotions for Sud de France products. Other interest groups are the inhabitants of the region and the national and worldwide consumers and tourists. Figure 4 illustrates the position and interrelations of the main stakeholders.

\footnotetext{
$\overline{{ }^{11} \mathrm{http}: / / \mathrm{www} . \text { suddefrance-developpement.com/fr/partenaires.html }}$
} 


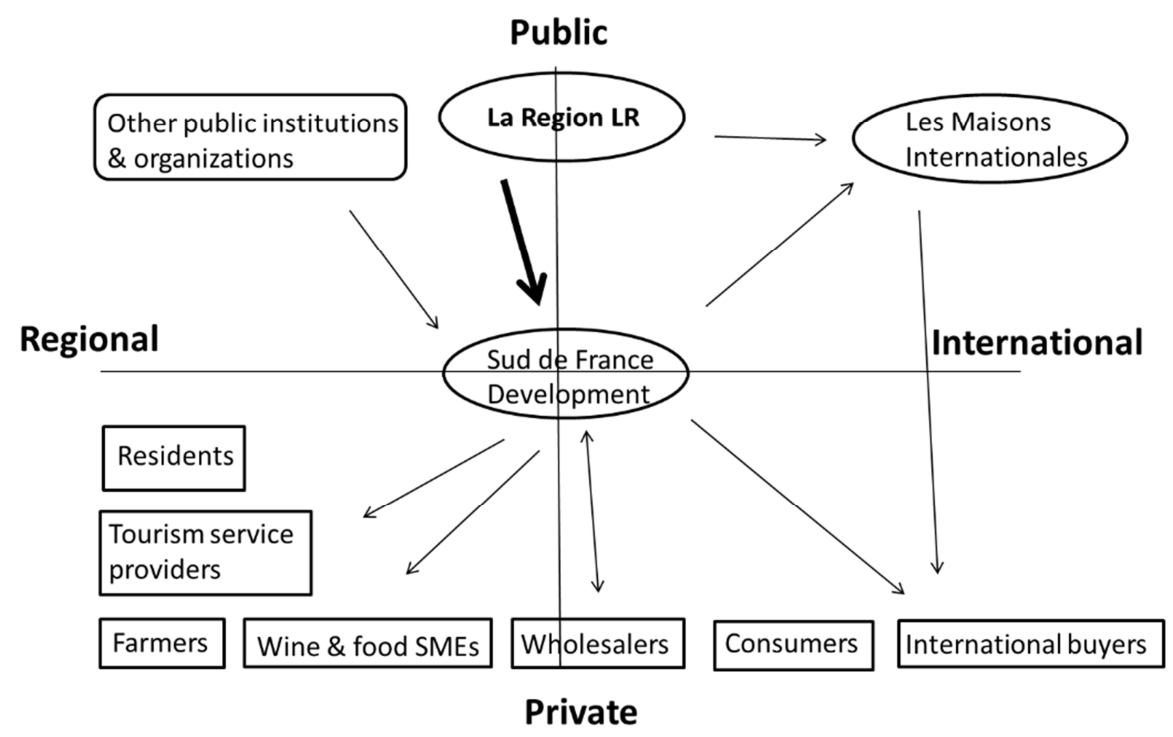

Figure 4: Positioning of the main stakeholders of the brand Sud de France

Source: authors

\subsubsection{Brand effects}

The effects of the Sud de France strategy have not yet been measured in detail. In order to capture the equity of the brand, we start with a presentation of mainly secondary data about the development and impact of the brand taken from different sources. Next, we concentrate on outcome patterns observed by key stakeholders in interviews.

In early stages, food enterprises were not enthusiastic about the brand, mainly because there had also been other failed collective brands before (Authentiquement Languedoc-Roussillon and Septimanie). Representatives from the government really needed to convince them to adhere, emphasising that Sud de France was not intended to be a substitute for their own brands, but an additional chance to create awareness and easier access to regional and international distribution channels. Some disagreement between various actors delayed an efficient implementation of the brand. However, the increasing total number of adherents (wine, food and tourism) in Table 3 demonstrates that the use of the brand has become attractive for local professionals. 
Table 3: Total number of adherents of Sud de France 2006 - 2013

\begin{tabular}{|c|c|c|c|c|c|c|c|}
\hline Year & $\mathbf{2 0 0 6}$ & $\mathbf{2 0 0 8}$ & $\mathbf{2 0 0 9}$ & $\mathbf{2 0 1 0}$ & $\mathbf{2 0 1 1}$ & $\mathbf{2 0 1 2}$ & $\mathbf{2 0 1 3}$ \\
\hline $\begin{array}{c}\text { Number of } \\
\text { adherents }\end{array}$ & 50 & 365 & 1,000 & 1,520 & 1,800 & 2,200 & 2,600 \\
\hline
\end{tabular}

Source: interviews and secondary data (www.lalettrem.fr and www.suddefrance.com)

A general study about the evolution of the regional agricultural sector (1997-2009) confirms the interest of food companies for the brand (De Caix et al. online document 2011). In 2009, the brand was used by $36 \%$ of the enterprises in the agri-food sector. In the wine sector, the percentage of adherents was 50\%. From 2009 to 2012, the total number of adherents grew considerably. In 2013, the estimated percentage of participating food companies was about $90 \%$ (Interview C. Passat, 14 June 2013). Access to activities offered by Sud de France Development is given under the condition to become a brand member; companies took this for granted.

Another investigation in 2009 about the perception of Sud de France among 503 regional food enterprises produced the following statements, which demonstrated a major level of satisfaction (Agreste online document 2011):

- $80 \%$ of the companies declared that the brand contributes to increase the awareness of regional products on export markets;

- $72 \%$ of them considered that it helps to better sell their products;

- $68 \%$ believed that it contributes to create new markets.

Concerning the sales impact of the brand on the French large retail groups, results confirm that the promotional summer campaigns organised by Sud de France Development are profitmaking. ${ }^{12}$ In 2010, the average sales increase of local food products labelled Sud de France within supermarkets has been $20 \%$ at regional level and even $30 \%$ at national level, compared to 2008 and 2009 , when the increase was $5-10 \% .^{13}$

\footnotetext{
12 "Large retailers are not philanthropic. If they repeat actions, it is because they profit from them", analyses Chantal Passat. Cited from: www.lalettrem.fr (28 February 2012), translated by authors.

${ }^{13}$ http: lalettrem.fr, 17 November 2009 and 18 January 2011.
} 
In order to obtain figures from export, an economic analysis has been carried out for Sud de France wines in 11 countries from 2006 to 2011. The majority of destinations show a growth of sales volumes and profit, mainly in Asia and Brazil (Percq online document 2012). China is an exceptional leader, multiplying sales by 7 and profit by 8 times initial levels from 2006 to 2010 . In this case, the region is the second to Bordeaux. From the beginning China was a main target country, a policy reinforced by the Maison Internationale in Shanghai including regular participation in important trade fairs. Furthermore, the analysis shows Sud de France wines to have a better resistance to global crises in the sector, and this is partially a result of the enormous quality improvements of Languedoc-Roussillon wines in general. ${ }^{14}$

There is not so much evidence from consumer side concerning Sud de France. In 2007, just one year after the brand launch, a study about the perception of the brand among regional inhabitants was carried out by TNS Sofres (online document 2007). At this time, only $43 \%$ of the respondents knew of the brand. About $63 \%$ had a positive attitude towards this regional project, while on average $20 \%$ which had a negative one. In 2013, the brand reached a high level of awareness at regional level (about $90 \%$, according to the result of a confidential study done by a private consultancy), but it seemed that people could not define the content of the brand and didn't know what it represents. However, from the perspective of wine experts, the benefits of Sud de France for consumers lies principally in the fact that it increases the awareness of provenance and facilitates the choice among a partly confusing multitude of references and quality signs in the French wine world. ${ }^{15}$

We performed thirteen interviews between November 2012 and June 2013, with persons from public institutions, representative organisations, various private companies and a tourism provider. The main objective was to investigate the perceived value added by Sud de France. A secondary question was whether the brand is helping to create a network of local actors.

\footnotetext{
14 "Within a worldwide context of crises, Sud de France wines resist well and sometimes better than others." Cited from: Panayoty and Bouchindhomme (online document 2012), translated by authors.

15 "The average consumer is not able to cite only five names of wines and doesn't make the difference between a brand and a PDO (protected designation of origin)... We think that Sud de France is the only name susceptible to be kept in mind by the average consumer..." Cited from Galbrun (online document 2012), translated by authors. See also McGinty C. (online document 2008) and Dominé A. (online document 2012).
} 
Table 4: Highlights of the interviews about the value of Sud de France

\begin{tabular}{|c|c|c|c|}
\hline $\begin{array}{c}\text { Institution, } \\
\text { Person \& function }\end{array}$ & Value added & Network & Further comments \\
\hline $\begin{array}{l}\text { Sud de France } \\
\text { Development } \\
\text { Chantal Passat, } \\
\text { responsible for the } \\
\text { agri-food sector }\end{array}$ & $\begin{array}{l}\text { "What food enterprises do expect } \\
\text { from the brand is to guarantee their } \\
\text { existence, to keep them on the } \\
\text { markets... The brand helps them to } \\
\text { persist in times of crises." }\end{array}$ & $\begin{array}{l}\text { "Yes, the brand enables a } \\
\text { coordination of local actors; } \\
\text { there is a collective spirit } \\
\text { among food enterprises. We } \\
\text { also try to group them and } \\
\text { bring them together with } \\
\text { tourism." }\end{array}$ & \\
\hline $\begin{array}{l}\text { LRIA (Languedoc- } \\
\text { Roussillon Industries } \\
\text { Agro-Alimentaires) } \\
\text { Anne Gérard, } \\
\text { project officer }\end{array}$ & $\begin{array}{l}\text { "Regional food enterprises are very } \\
\text { happy with the existence of the } \\
\text { brand... the main advantage for a } \\
\text { firm is the possibility to enter in } \\
\text { large distribution channels." }\end{array}$ & $\begin{array}{l}\text { "There is not yet a cluster or a } \\
\text { network of enterprises around } \\
\text { the brand, but it's in } \\
\text { development, there are several } \\
\text { initiatives, like trades, meetings } \\
\text { etc." }\end{array}$ & \\
\hline $\begin{array}{l}\text { Invest Sud de France } \\
\text { Pascal Ehrhardt, } \\
\text { assistant manager }\end{array}$ & $\begin{array}{l}\text { No visible economic impact of the } \\
\text { brand on the region, but it creates } \\
\text { an image and makes the region } \\
\text { visible, above all at international } \\
\text { level. }\end{array}$ & No network effect until now. & $\begin{array}{l}\text { "In the USA, nobody knows } \\
\text { Languedoc-Roussillon. Sud de } \\
\text { France has more awareness, } \\
\text { as it is much easier to keep in } \\
\text { mind and to localize." }\end{array}$ \\
\hline $\begin{array}{l}\text { Conseil Régional } \\
\text { Languedoc- } \\
\text { Roussillon } \\
\text { Laurence Serrano, } \\
\text { director of the Sud de } \\
\text { France department }\end{array}$ & $\begin{array}{l}\text { "The brand has two values: } \\
\text { An economic one for enterprises, as } \\
\text { communication and } \\
\text { commercialisation tool. } \\
\text { An institutional one that gives value } \\
\text { to the region as a whole, by } \\
\text { increasing the awareness and } \\
\text { creating a common strong identity. } \\
\text { This includes an extension of the } \\
\text { brand to other sectors" }\end{array}$ & $\begin{array}{l}\text { "Until now, there is no strong } \\
\text { formal network around the } \\
\text { brand; enterprises are } \\
\text { registered in a database. But } \\
\text { there are common promotion } \\
\text { activities, which allow actors } \\
\text { getting in contact and } \\
\text { exchanging information." }\end{array}$ & \\
\hline $\begin{array}{l}\text { CIVL (Conseil } \\
\text { Interprofessionnel } \\
\text { des vins du } \\
\text { Languedoc) } \\
\text { Jérôme Villaret, } \\
\text { general director }\end{array}$ & $\begin{array}{l}\text { "Sud de France makes export } \\
\text { easier, it helps the enterprises; but } \\
\text { there was a structural change and } \\
\text { new strategy in the Languedoc- } \\
\text { Roussillon wine sector before... the } \\
\text { brand is a multiplicator." }\end{array}$ & $\begin{array}{l}\text { Yes, the brand has a positive } \\
\text { influence on local cooperation; } \\
\text { it has grouped different } \\
\text { organisations within the wine } \\
\text { sector which did not } \\
\text { communicate before. }\end{array}$ & \\
\hline $\begin{array}{l}\text { Fédération Régionale } \\
\text { des Fruits \& } \\
\text { Légumes } \\
\text { Rafael Martinez, } \\
\text { director of the } \\
\text { federation }\end{array}$ & $\begin{array}{l}\text { "It's difficult to measure the impact } \\
\text { of the brand in economic terms, but } \\
\text { main advantages are: easier export, } \\
\text { access to retail groups and } \\
\text { participation in actions organised } \\
\text { by Sud de France Development } \\
\text { (trade fairs as MEDFEL)." }\end{array}$ & $\begin{array}{l}\text { Yes, the brand creates a } \\
\text { network of public and private } \\
\text { actors through common actions, } \\
\text { which allow exchanges of } \\
\text { information and know-how. }\end{array}$ & \\
\hline $\begin{array}{l}\text { Cooperative Olidoc } \\
\text { (olive oil) } \\
\text { Hélène Pages and } \\
\text { Christine Aubouy }\end{array}$ & $\begin{array}{l}\text { Already before, the olive oil sector } \\
\text { needed to be reorganised to } \\
\text { improve quality. But now there is } \\
\text { more motivation because this is } \\
\text { reinforced and controlled. }\end{array}$ & $\begin{array}{l}\text { Yes, there is a network of } \\
\text { actors; you meet always the } \\
\text { same people. } \\
\text { The brand also helps to know } \\
\text { retailers, this cooperation has } \\
\text { really improved. }\end{array}$ & $\begin{array}{l}\text { "Without help of Sud de } \\
\text { France Development, I would } \\
\text { have stopped activities here at } \\
\text { local level... } \\
\text { Quality is important and also } \\
\text { product origin in order to } \\
\text { avoid a damage of the } \\
\text { image." }\end{array}$ \\
\hline
\end{tabular}




\begin{tabular}{|c|c|c|c|}
\hline $\begin{array}{l}\text { Les Brasérades } \\
\text { (meat \& sausages) } \\
\text { Clemence Pitiot, } \\
\text { director marketing }\end{array}$ & $\begin{array}{l}\text { The brand gives access to big } \\
\text { supermarkets, the firm profits from } \\
\text { the brand awareness, and the brand } \\
\text { also increases their sales volume. }\end{array}$ & $\begin{array}{l}\text { There is no network, but they } \\
\text { know some other enterprises, } \\
\text { mainly the pioneers; they are } \\
\text { also in the group who defines } \\
\text { the new quality book. }\end{array}$ & $\begin{array}{l}\text { "We have been one of the } 10 \\
\text { first adherents of Sud de } \\
\text { France. The brand } \\
\text { corresponds exactly with the } \\
\text { policy of our company, as we } \\
\text { share the same values. } \\
\text { A problem is the enormous } \\
\text { increase of members, which } \\
\text { not always have typical } \\
\text { products of the South or good } \\
\text { quality." }\end{array}$ \\
\hline $\begin{array}{l}\text { Médithau Marée } \\
\text { (oysters and mussels) } \\
\text { Jean-Jacques Thibaut, } \\
\text { general secretary }\end{array}$ & $\begin{array}{l}\text { "Our products are not really } \\
\text { suitable to a use of the brand-as } \\
\text { mostly private label and food } \\
\text { provenance from abroad. But big } \\
\text { advantages are the awareness of } \\
\text { the region abroad and information } \\
\text { about foreign markets." }\end{array}$ & $\begin{array}{l}\text { Yes and no. It is more through } \\
\text { other regional projects is the } \\
\text { program AGIR that actors } \\
\text { cooperate. }\end{array}$ & $\begin{array}{l}\text { "We highly appreciate the } \\
\text { services offered by Sud de } \\
\text { France Development. Their } \\
\text { internet site provides an } \\
\text { excellent tool." }\end{array}$ \\
\hline $\begin{array}{l}\text { CMJ (sweet local } \\
\text { specialties) } \\
\text { Stéphanie Rabaud, } \\
\text { export department }\end{array}$ & $\begin{array}{l}\text { The advantage is to enter in the } \\
\text { advertising folders of the retailers } \\
\text { and to have a common } \\
\text { communication tool. }\end{array}$ & $\begin{array}{l}\text { Yes, local actors come together } \\
\text { through the operations } \\
\text { organised by Sud de France } \\
\text { Development. This delivers } \\
\text { information exchange with } \\
\text { others. }\end{array}$ & $\begin{array}{l}\text { There have been problems } \\
\text { due to quality differences } \\
\text { between companies using the } \\
\text { brand; this has led to } \\
\text { dissatisfaction among } \\
\text { enterprises and consumers. }\end{array}$ \\
\hline $\begin{array}{l}\text { Domaine Massillan } \\
\text { (wine) } \\
\text { Guillaume Reboul, } \\
\text { owner }\end{array}$ & $\begin{array}{l}\text { As they don't have an own brand, } \\
\text { the brand increases the awareness } \\
\text { among consumers and saves costs } \\
\text { for own marketing. }\end{array}$ & $\begin{array}{l}\text { There is no specific cooperation } \\
\text { among brand members, in } \\
\text { opposite to a syndicate. But you } \\
\text { meet the others during common } \\
\text { actions. }\end{array}$ & $\begin{array}{l}\text { "The brand allows us } \\
\text { entering at the international } \\
\text { scene. } \\
\text { Sud de France is a great } \\
\text { name. Languedoc-Roussillon } \\
\text { plays successful the card of } \\
\text { the region." }\end{array}$ \\
\hline $\begin{array}{l}\text { Domaine Rieussec } \\
\text { (wine) } \\
\text { Marie-Hélène } \\
\text { Deltort, } \\
\text { owner }\end{array}$ & $\begin{array}{l}\text { "We don't have an own brand. } \\
\text { Therefore, Sud de France is an } \\
\text { ideal communication tool for us." }\end{array}$ & $\begin{array}{l}\text { Yes, the brand helps to } \\
\text { approach local actors. If you } \\
\text { participate in common actions } \\
\text { as trade fairs or forums, you get } \\
\text { in contact with other producers. }\end{array}$ & \\
\hline $\begin{array}{l}\text { Aquarium Mare } \\
\text { Nostrum (tourism) } \\
\text { Christian Rigaud } \\
\text { employee }\end{array}$ & $\begin{array}{l}\text { The big advantage is to have } \\
\text { promotion for free. This attracts } \\
\text { many national and international } \\
\text { visitors. }\end{array}$ & $\begin{array}{l}\text { "No, there is no network of } \\
\text { adherents of the brand. This is a } \\
\text { pity." }\end{array}$ & $\begin{array}{l}\text { "The value of the brand is } \\
\text { enormous, seen the } 75.000 \\
\text { visitors per year due to the } \\
\text { promotion." }\end{array}$ \\
\hline
\end{tabular}

Source: semi-structured interviews with regional public and private stakeholders

The stakeholders' evaluations reflect four main tendencies. First, the brand provides benefits for regional institutions such as the creation of a common identity and international reputation, which allows a stepwise brand extension to other domains. Also private stakeholders mention to have profited from the increasing awareness of Sud de France. Second, the value for firms mainly lies in cost savings for marketing and access to distribution channels at regional, national and international levels. The brand contributes to a better product commercialisation. It thus helps to withstand economic crises and to secure the continued existence of firms. Other perceived advantages are the services provided by Sud de France Development, such as the organisation of 
trade fairs and festivals as well as market information. For tourism providers, the brand helps to attract worldwide visitors and to guarantee the quality of their stay. ${ }^{16}$ Third, there is yet no consensus on whether the brand contributes to the development of a regional network. Until now, exchanges seem to be rather casual - when brand adherents meet each other at trade fairs, forums or festivals - yet stronger cooperation between actors is envisaged. Fourth, the further development and success of Sud de France now depends on a new quality definition for its food products, as this is not only a cause of debate and dissatisfaction among enterprises, but also bears the risk of creating a negative brand image.

While the main stakeholders of Sud de France are quite positive about the brand, other voices have been more critical. The principal point of controversy has been the public expenses for Sud de France. They are claimed to be too excessive, a fact, which was brought up in relation to an enormous general increase of taxes during the presidency of G. Frêche, the creator of the brand. ${ }^{17}$ It has also been argued that the region Languedoc-Roussillon was subjected to an excessive exposure in the media, spending a large sum of public money, and according to criticasters, overestimating its real value (Roques 2010). ${ }^{18}$ The regional government is not willing to communicate the exact budget invested in the brand. One may ask if brands have become indispensable for places or if they are rather a marketing fad. One of the interviewees stated: "Territorial marketing has become a fashion in France; but it has also become necessary to differentiate from other competitors, in much the same way as any company." (Interview P. Ehrhardt, 5 February 2013).

\subsection{Analysis of the case study and discussion}

We come back to the initial question of place brand effects. In other words: Does the brand work? The case study has shown that Sud de France has quite a number of positive effects on its different stakeholder groups, which are, in general, satisfied with the brand. Its main tangible, i.e. measurable assets are: a constantly growing number of brand members, sales increase in supermarkets, an increase of export figures for labelled wine, brand awareness among consumers

\footnotetext{
${ }^{16} \mathrm{http} / / /$ draaf.languedoc-roussillon.agriculture.gouv.fr/Tourisme-rural

${ }^{17}$ See for example articles www.observatoiredessubventions.com. These opinions being published one month before the regional elections which took place in March 2010 show the politicization of this place brand.

18 "Languedoc Roussillon is the region which dedicates the most important budget for its communication, 4.50 euro per inhabitant each year vs. 1.50 euro in Ile-de-France. To resume, the region Languedoc Roussillon, but maybe it cannot do otherwise, spends a lot to exist." Cited from Ballout (online document 2011), translated by authors.
} 
within the region, and attraction of tourists. Valuable qualitative benefits for brand users are: better market access, general awareness, options for marketing and participation of sales and promotional activities.

It has been more difficult to assess the value of another, intangible asset, namely the creation of a network. Contrasting answers given by stakeholders concerning this issue also show the problem of impact attribution. It appears difficult to define whether the brand is leading to stronger cooperation, going further than normal business exchanges. The same attribution problem applies to the impact of the brand on enterprises in economic figures, as interviewees could not define the contribution of the brand to their company sales and profit.

Nevertheless, the overall brand effects of Sud de France are considerable and the brand has persisted for eight years. It constitutes a means to support the performance and the existence of small economic actors, to valorise and preserve the diversity of local assets (wine, food, and sites), to create an image for a somewhat marginalised region as well as to strengthen its longterm competitiveness. Economic and institutional values are, in this case, more obvious than social or ecological ones. Financial efforts for the brand can be considered as public development support rather than as a 'classical' marketing instrument to win consumers and to add value to a firm by a price premium. ${ }^{19}$ However, in order to avoid criticism, the regional government must also prove the public that resources are well spent since the resulting value of Sud de France is a useful tool for the socio-economic development of Languedoc-Roussillon.

Moreover, the analysis of Sud de France has offered useful insights about mechanisms and critical success factors of place brands, which confirm the initial assumption that a more holistic approach for their assessment is needed. (How does it work? Will it work elsewhere?).

First, place brands can be considered as collective projects, taking place within a system of horizontal and vertical relations, even if they are owned and governed by one main institution. Therefore, it is essential to incorporate the motivation and satisfaction of the multitude of stakeholders involved. Our case analysis has shown that a place brand does not only rely on multiple relations whose coordination is important, but even that it can completely fail if it is disapproved by one (secondary) stakeholder group. E.g. the primary brand name, Septimanie, had to be given up after two years of intensive promotion, as it was rejected by a group of inhabitants.

\footnotetext{
${ }^{19} \mathrm{Cf}$. the argumentation of G. Frêche (La Gazette 2012): "We'll spend the maximum (of budget). I prefer to invest there instead of giving money for single interventions which always need to be renewed and don't regulate anything. We will not save the wine growers by paying loan interests!"
} 
Second, place brands can have multiple, economic and non-economic outcomes. Sud de France confirms this initial theoretical assumption made by Jones (2005). The effects of this branding initiative are indeed various, as they derive from different sectors - covered by the umbrella brand - and different stakeholder groups. They cannot only be measured in terms of profitability, but also entail other, non-economic benefits such as an increase of regional awareness, a boost of small firms or the preservation of a diversity of typical local products. A further benefit, already in development, lies in the enhancement of local cooperation - leading to a network of different actors. Another potential consists in an extension of the brand, e.g. by creating synergies as oenotourism and agrotourism. ${ }^{20}$

Third, the equity of place brands also depends on their articulation with their legal, social, economic and political context. Examples for the Sud de France macroeconomic environment are the worldwide economic crises or the French consumer trend for terroir products and short distribution channels. Also the fact that the new regional presidency in Languedoc-Roussillon has reinforced the development of the tourism sector will most probably have a positive influence on the general brand performance. ${ }^{21}$ Tourism and short distribution channels may be strongly related since tourists show a tendency to buy local products for their own consumption and for souvenirs (e.g. the increasing sales figures of major supermarkets in summer).

Finally, it is relevant to take into account the time aspect of place brands, as they need a relatively long time to establish. This is due to complex management and coordination, brand extensions, as well as perception and acceptance by consumers and brand users. For example, the difficulties in the beginning and the yearly growing number of Sud de France members could show that considerable time is needed. This is also why the former president of Languedoc-Roussillon wanted to invest quickly and efficiently in the place brand: "It is important to act quickly, as the establishment of a brand at international level needs at least ten years" (LaGazette 2012). A wine expert confirms this point of view, arguing that Sud de France will enter the consumer mind as is Bordeaux, over several years, provided that the region has resources to further finance the brand (Interview J. Villaret, 12 January 2013). The time factor of place brands thus requires a long-term orientation instead of a focus on short-term results. It also means to determine a suitable moment for evaluations as well as for brand extensions and/or repositioning.

\footnotetext{
${ }^{20} \mathrm{http} / / /$ draaf.languedoc-roussillon.agriculture.gouv.fr/Tourisme-rural

${ }^{21}$ www.laregion.fr
} 


\subsection{Conclusion}

Propositions on how to measure the performance of place brands are increasingly needed for academic researchers, policy makers and place managers. With this article, we have contributed to the discussion by presenting and evaluating a regional branding initiative in the South of France.

The umbrella brand Sud de France, with its 2.600 adherents, multiple stakeholders and different application areas, has once more shown the complexity of place brands; entailing difficulties for their impact evaluation. The investigation of brand performance was based on a case study. On the one hand, statistical data from various secondary sources was collected in order to document the yearly increase of brand adherents, sales and export figures related to the brand and degrees of satisfaction among enterprises and consumers. On the other hand, a set of qualitative interviews with public and private stakeholders was carried out by the authors, reflecting various, mainly positive opinions on the value of the brand and its contribution to local cooperation. This approach has been limited by several factors, such as a lack of available statistical data or the reluctance of the Languedoc-Roussillon government, the brand owner, to give detailed information (e.g. about the budget or results from consumer studies). Furthermore, it would have been useful to obtain arguments from local actors that are not brand adherents, even though they are not many. However, the combination of hard and soft data, the consideration of various stakeholders and their opinions - including critical voices -, as well as the representation of the context of this place brand (origin, strategy, governance) have allowed capturing the effects of the Sud de France branding strategy. Via this multiple approach, we have shown the usefulness of this brand as a strategic tool for the sustainable development of the region.

Moreover, from this case study we have gained insights about working mechanisms and evaluation methods for place brands, which confirm the initial assumption that a more holistic approach for their assessment is needed. As place brands are collective projects, an impact evaluation including multiple stakeholder perspectives has turned out to be more adequate than a one-sided approach from only a consumer side. The latter may be interesting for the communication strategy, but will not suffice to define the overall brand value. Thereafter, an evaluation should not only be restricted to economic outcomes, but should also include noneconomic effects induced by place brands. For example: a common identity, the preservation of local intangible assets or the creation of cooperation among stakeholders, even if those benefits 
are more difficult to measure and to attribute directly to the brand. However, such an approach will prevent the definition of pure economic indicators. Moreover, an evaluation of place brands should take into account their embeddedness in a cultural, political and macro-economic context, considering conditions which boost or constrain place brand performance. This may also lead to a brand repositioning or improvements. The intensification of the tourism sector in Sud de France policy, for example, may require a redefinition of food criteria to create more coherence. Finally, consideration of the time aspect is crucial for impact evaluations, as place brands need a long time to establish. Therefore, a short-term analysis is not practical, but rather one should look at long-term outcomes. A brand life cycle analysis could even be useful, determining the state-ofthe-art, and analysing drivers for changes within specific time periods.

Summing it up, if place brands derive from public policies and aim at the long-term development of places, measuring their overall value can perfectly follow evaluation logics for public development interventions, with basic evaluative questions and mixed methods. By doing this, it will not only be possible to deal with time and budget constraints for evaluators, but also to draw generic conclusions and to fulfil the need for accountability of governmental stakeholders and for creating knowledge for all those concerned with place branding (academics, place managers, policy makers). 


\section{CHAPTER 3}

What kind of value for place brands? A stakeholder approach

This chapter has been the basis for an article in French submitted to Management International. Mechthild Donner, Fatiha Fort: Quelle valeur des marques territoriales? Une approche par les parties prenantes. 


\section{Chapter 3}

\section{What kind of value for place brands? A stakeholder approach}

\section{Summary}

Place branding is an interdisciplinary concept which has gained importance in practice and academic research. Concerning various public and private stakeholders, it is inseparable from political and social questions. Among these, legitimacy and accountability are particularly important for governments and policy makers. Furthermore, there is a need to know the extent to which those brands can contribute to the sustainable development of places, strengthen the bargaining position of SMEs, enhance the quality of consumers' life, or increase welfare even in marginalised areas. As there is not yet a generally accepted way to define and measure those potential benefits, we here stepwise develop a measurement model and monitoring tool for the value of place brands with regard to the specific governance characteristics and stakeholders involved. In order to do so, we first identify key internal place brand stakeholders, including local governments, enterprises, residents and consumers, and thereafter, we establish a set of indicators of place brand value which correspond to the perceived or expected brand benefits for these stakeholders. These indicators are then translated into response profiles and tested with the brand Sud de France, via a quantitative survey among residents and consumers. Regularly used, this methodology can serve for managing and monitoring place brand performances. 


\subsection{Introduction}

In the past two decades, the application of marketing and branding strategies has become increasingly popular among cities, regions and countries. It is assumed that this growing tendency will continue (Dinnie 2008, Kotler et al. 2004). It seems that place brands derive mainly from public policies. Potential application areas and target groups of place brands and public policies are similar. Not only can they relate to people, culture and heritage, local enterprises and their products, but also to tourism, trade and investment (Anholt 2006). Thus, they can address internal (citizens, local firms), as well as external (export, foreign investors, tourists) target groups. Empirical cases show that place brands often are used as an economic, as well as public, institutional tool. For Simon Anholt, who is considered as the 'founding father' of the concept, the practice of place branding is "the management of place image through commercial, social, cultural and government policy" (Gertner 2007: 3). This is so far the widest conceptualisation of place branding, because it links marketing with policy, stakeholders and target groups.

Academic literature on place branding also suggests that there are - more or less strong - links between the marketing of places and public diplomacy (Anholt 2006, Gertner 2007, Szondi 2008, Van Ham 2001). It is argued that the intersection between place marketing and (international) politics results from a common interest in "concepts such as globalization, identity, values and power" (Van Ham 2008: 127).

As globalisation and regionalisation lead to increased competition among territories, differentiation becomes necessary, even for smaller geo-political entities such as regions or cities. At the same time, options to select preferential places for consumers and investors have increased due to enhanced mobility and new information systems. The need to attract tourists, companies and skilled people and to find markets for exports, requires that places adopt marketing and branding practices (Kotler \& Gertner 2002). This is why more and more territorial governments tend to use place brands as strategic tools for differentiation and local sustainable development.

On the other hand, place brands are considered to be resulting from a shift from hard to soft, postmodern power (Van Ham 2008). This is the case if governments follow a paradigm change from coercion to persuasion, and from compulsion to more attraction, and therefore essential principles of marketing (Anholt 2006). Thus, especially in countries where political programmes and ideologies are losing relevance, politicians may use place brands as communicators for lifestyles, emotions, norms and values. The place branding concept, then, is "not only about 
'selling' products, services, and ideas and gaining market share and attention; it is also all about managing identity, loyalty, and reputation" (Van Ham 2008).

What are the consequences from these observations and insights? If place brands principally arise from public and political decisions but concern various stakeholders within a territory, and/or favour specific target groups, measuring their value and legitimacy becomes a key issue. This is even more the case since considerable tax incomes are spent for place marketing activities (Jacobsen 2009). Policy makers must prove that place brands are not a 'fashion', wasting taxes for communication, but that they may constitute a useful strategic tool for sustainable local development from which various stakeholders may profit. Thus, there is a need to know what those brands can offer, who is benefitting from them, how their effects can be measured, and whether public resources are fairly spent. This is even more important as place branding and marketing suffer to a certain extent from a bad reputation and scepticism (Dinnie 2008, Szondi 2008). However, until now, in place branding literature "there has hardly been any discussion on how (place) brand equity should be interpreted and how it should be measured" (Florek 2015: 230).

In order to fill the gap in the existing academic literature, to provide a more transparent view on the potential value of place brands for different territorial stakeholders, and to fulfil the need of policy-makers and place managers for legitimacy and accountability, we stepwise develop in this article a measurement model and monitoring tool for place brand value, based on the Sud de France case in the Languedoc-Roussillon region. We first draw a literature review on brand equity and value in order to highlight the specificities of place brands. Then, we identify main stakeholders involved and explain the methodology used. Afterwards, we develop and test a model to measure the value of place brands and propose a monitoring tool for place brand performances. Finally, we discuss the theoretical and managerial implications of our contribution. 


\subsection{The value of brands}

The practice of modern branding started in the end of the $19^{\text {th }}$ and the beginning of the $20^{\text {th }}$ century in the United States (Low \& Fullerton 1994), when an increasing crowded marketplace encouraged firm owners and entrepreneurs to promote their products by building recognisable and distinctive identities (Hankinson 2010). At this time, some of today's most famous brands such as Coca-Cola, Gillette or Heinz emerged (Hankinson \& Cowking 1993). However, academic interest for branding only materialised in the 1950s. Gardner and Levy (1955: 35) were one of the first to recognise that a brand is more than a name, defining it as "a complex symbol that represents a variety of ideas and attributes". In the late 1970s, takeovers of large brandowning companies led to the insight that brands can have their own value, a part from the product (Srinivasan 1979) and that they can build real corporate assets (Doyle 1989). Since then, there has been an increasing academic interest in the concepts of brand equity (Keller 1993) and strategic brand management (Kapferer 1991).

The large amount of research has shown that brand equity is a multi-dimensional concept. In marketing literature, as well as from practical accounting side, there is no consensus, but rather heterogeneity of definitions and measurement approaches (Kapferer 2008, Wood 2000). The most common approaches are either consumer-based and analyse consumers' perceptions and behaviour (Aaker 1996, Keller 1993), or they measure the financial impact of a brand on the company (Simon \& Sullivan 1993). Approaches coming from service marketing define brand value based on its capacity to create and maintain costumer relations (De Chernatony \& SegalHorn 2003, Grönroos 2001, Gummesson 2002). With regard to corporate brands, the focus has been broadened from consumer to multiple audiences and to stakeholder-based brand equity models (Aaker 2004, De Chernatony \& Harris 2000, Jones 2005). Finally, literature dealing with 'country equity', until now, has mainly researched country images and perceptions by the consumer, explaining consumer preferences for products of specific countries (Dinnie 2004, Papadopoulos \& Heslop 2002, Verlegh \& Steenkamp 1999).

Three points seem have a shared importance for the brand equity concept (Changeur 2002, Leuthesser 1988): first, a brand is bringing a supplementary performance or added value to a product (a company, or a place); second, it can be regarded and measured from the consumer side and/or from a firm perspective; third, a brand has a competitive dimension and a temporary (long-term asset) one. These issues are also relevant for place brands and the term 'place brand 
equity' has until now followed classical definitions. For Gertner (2007: 6) - similar to the extensive definition of Farquhar's 'added value' (1989) - place branding for a country is “an opportunity to add or subtract value to its equity”. Papadopoulos (2004: 43) builds on Aaker's proposition (1991) and defines place equity as "the real and/or perceived assets and liabilities that are associated with a place and distinguish it from others."

However, due to the specific characteristics of place brands, we argue that they need a different and broader equity conceptualisation than product or corporate brands (Donner et al. 2014). First of all, place brands are collective projects, which involve a multitude of public and private stakeholders (Kavaratzis 2012, Rainisto 2003). Therefore, a one-sided consumer- or firm-based approach will not suffice. Second, place brands are also policy instruments (Anholt 2008, Van Ham 2008) and can be used either as communicators for norms and values or as tools for local development. Thus, they include not only economic, but also political, social and cultural dimensions and have rather a long-term orientation. Another important point is that place brands, from a brand management point of view, are very complex and not fully controllable (Braun \& Zenker 2010, Kavaratzis 2005, Moilanen \& Rainisto 2008). Due to these specificities, we develop a measurement model and propose a monitoring tool, which both encompass multiple dimensions as well as multiple stakeholders. In Table 5, building on Fan (2010), we highlight the main differences between product, corporate and place brand and existing brand equity conceptualisations. 
Table 5: Differences between product, corporate and place brand

\begin{tabular}{|c|c|c|c|}
\hline & Product/service brand & Corporate brand & Place brand \\
\hline Designation & A product or service & $\begin{array}{l}\text { A company or organisation } \\
\text { and its products/services }\end{array}$ & $\begin{array}{l}\text { A place and its products, services, } \\
\text { organisations, events... }\end{array}$ \\
\hline Image & Simple, clear & Simple, visible or hidden & Complicated, diverse, vague \\
\hline Audience & Targeted segment & General public or targeted & Diverse, local and international \\
\hline Stakeholders & $\begin{array}{l}\text { Double: company and } \\
\text { targeted group }(s)\end{array}$ & $\begin{array}{l}\text { Internal (shareholders, } \\
\text { employees) and external } \\
\text { (customers, partners, } \\
\text { media...) }\end{array}$ & $\begin{array}{l}\text { Internal (governments, } \\
\text { organisations, firms, residents) and } \\
\text { external (tourists, foreign investors) }\end{array}$ \\
\hline Objectives & $\begin{array}{l}\text { Increase sales/profit and } \\
\text { develop brand loyalty }\end{array}$ & $\begin{array}{l}\text { Enhance a company's } \\
\text { value and its reputation, } \\
\text { develop relationships }\end{array}$ & $\begin{array}{l}\text { Enhance international awareness } \\
\text { and reputation, increase sales of } \\
\text { local products and services, create a } \\
\text { common identity, stimulate local } \\
\text { cooperation }\end{array}$ \\
\hline $\begin{array}{l}\text { Brand equity } \\
\text { definition }\end{array}$ & $\begin{array}{l}\text { Value added to a product by } \\
\text { a brand (Farquhar 1990) }\end{array}$ & $\begin{array}{l}\text { Value added to a company } \\
\text { by a brand }\end{array}$ & $\begin{array}{l}\text { Value added to a place and its } \\
\text { stakeholders by a brand }\end{array}$ \\
\hline Dimension & Mainly economic & Economic and social & $\begin{array}{l}\text { Political, economic, social and } \\
\text { cultural }\end{array}$ \\
\hline Time & $\begin{array}{l}\text { Short- and long-term } \\
\text { orientation }\end{array}$ & $\begin{array}{l}\text { Short- and long-term } \\
\text { orientation }\end{array}$ & Long-term orientation \\
\hline $\begin{array}{l}\text { Measurement } \\
\text { approaches }\end{array}$ & $\begin{array}{l}* \text { Consumer-based approach } \\
* \text { Financial approach } \\
\text { * Customer-relationship } \\
\text { approach }\end{array}$ & $\begin{array}{l}* \text { Stakeholder-based } \\
\text { approach } \\
* \text { Brand valuation for } \\
\text { accounting (Interbrand } \\
\text { Group) }\end{array}$ & $\begin{array}{l}* \text { Country image and consumer } \\
\text { perceptions }\end{array}$ \\
\hline Measures & $\begin{array}{l}\text { Qualitative: brand } \\
\text { awareness, association, } \\
\text { perceived quality, consumer } \\
\text { preferences, loyalty } \\
\text { Quantitative: price } \\
\text { premium, market share, } \\
\text { incremental cash flow }\end{array}$ & $\begin{array}{l}\text { Qualitative: reputation, } \\
\text { loyalty } \\
\text { Quantitative: brand value, } \\
\text { goodwill of a firm }\end{array}$ & $\begin{array}{l}\text { Qualitative: reputation, image } \\
\text { Quantitative: number of tourists and } \\
\text { investors, export figures }\end{array}$ \\
\hline
\end{tabular}

Source: authors, building on Fan (2010) 


\subsection{From identifying place brand stakeholders towards a monitoring tool}

Empirical cases show that the place branding process is often initiated by governments who seek to involve other public and private partners. Private actors directly involved in the process vary, depending on the core category and objective of branding. They comprise farmers, local industry, tourism providers, development or consulting agencies, etc. Target groups or audiences of place brands usually are residents, tourists, (inter)national consumers, traders, investors and political units; but theoretically, anyone around the world can be targeted.

Stakeholders have been defined as "any group or individual who is affected by or can affect the achievement of an organisation's objectives" (Freeman 1984: 46). Accordingly, stakeholder theory is based on the assumption that a firm's performance does not only depend on direct business relationships, but also on (trustful and fair) relations with a wider range of people and organisations, such as media, NGOs, the public opinion or competitors. Only recently, the marketing discipline has started to give more attention to this concept based on ethical principles (Ferrell et al. 2010, Jones 2005, Laczniak \& Murphy 2012), as witnessed by the special section on 'Stakeholder Marketing' in the Journal of Public Policy \& Marketing, in 2010. Applied to place brands, it means that an entire system is concerned, with chain as well as non-chain actors, from inside and outside the branded place. Success then can only be achieved if various stakeholder groups are considered in the branding process (Hankinson 2004, Morgan et al. 2003). Consequently, it is necessary "to satisfy key stakeholders according to their definition of what is valuable" (McAdam et al. 2005: 258). The identification of stakeholder groups and the construction of strong relationships with these groups constitute a crucial task for successfully developing a place brand (Stubbs \& Warnaby 2015).

Various means have been proposed in literature to classify stakeholders (stakeholder typologies, cf. Mitchell et al. 1997). As participation is not the only criterion, some authors propose a powerinterest matrix with four different types of stakeholder groups, according to their (low or high) degree of power and (low or high) degree of interest in the organisation (Ackermann \& Eden 2011). Mitchell et al. (1997) go even further and propose three attributes to identify stakeholders: the power of stakeholders to influence the firm, the legitimacy of the stakeholder's relationship with the firm, and the urgency of the stakeholder's claim on the firm. In this regard, these authors come up with seven different types of stakeholders. Finally, a classification can also arise from the nature of stakeholders (internal vs. external to the organisation), from their financial or social 
relationship with the firm (primary vs. secondary: primary being those who are essential for the wellbeing of the organisation and secondary being those with whom the organisation interacts but who are not essential for its survival, Clarkson 1995), from their ability to influence the organisation (their potential to threaten or to cooperate with the organisation (Savage et al. 1991), or from the kind of (inevitable, necessary, or desirable) interactions between stakeholders and an organisation (Podnar \& Jancic 2006).

For the purpose of investigating the value of place brands, we identify key stakeholders based upon the criteria power and interest, in order to distinguish between internal and external stakeholder groups. Internal key actors have an interest in the place branding strategy and strong power to support or boycott the brand. These stakeholders are co-constructors of the place brand, as they give an identity to the brand and contribute to the creation of its value. Key stakeholders are (1) local governments which generally are the owners of the place brand and entrust development agencies with their management; (2) enterprises which directly use (and co-invest in) the brand for their products and services; (3) residents who, via their election, can influence the brand strategy; and (4) consumers who finally critically contribute to the success or failure of a brand by buying and consuming the labelled products and services.

Figure 5, below, shows the four key internal stakeholders in place branding. For the measurement model, some groups may partly overlap, which means residents can also be consumers, and firm employees can also be residents or consumers.

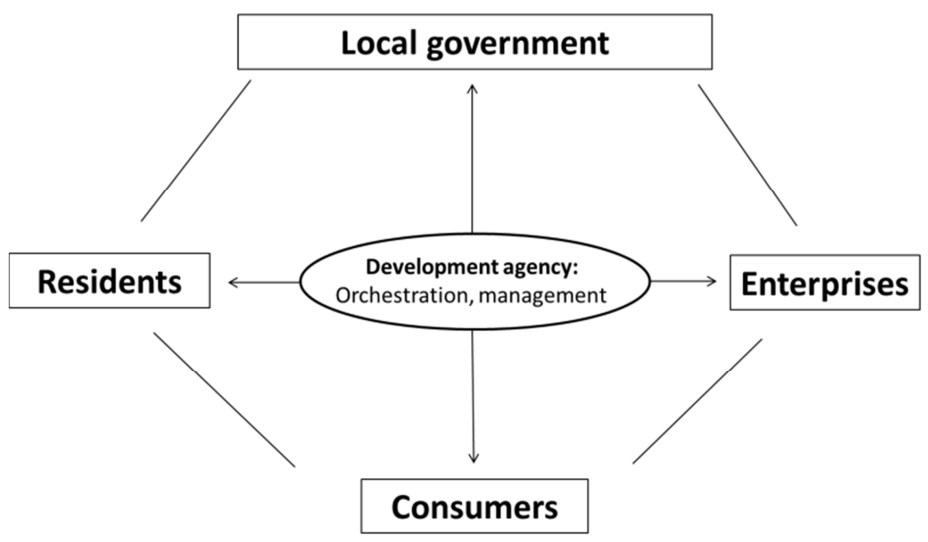

Figure 5: Primary internal stakeholder groups in place branding

Source: authors 
For place brand managers, it will be necessary to evaluate the value of the place brands for each stakeholder group in order to regularly control the place brand performance.

One of the management tools recognised in academic and professional literature to steer the performances of organisations is the Balanced Scorecard (BSC), proposed by Kaplan and Norton (1996). The BSC combines financial with non-financial measures, all related to the global performance of the enterprise. In its original form, the BSC is organised in four principal axes which are: the financial axis, the customer axis, the axis of internal business processes and finally the axis of learning and growth (Chabin et al. 2003). The model of Kaplan and Norton has undergone numerous evolutions in order to take into account the more recent notions of CSR (corporate social responsibility) and of sustainable development. Trébucq (2011), for example, criticises the narrow vision on shareholders and proposes to widen the BSC to other stakeholders. The BSC has also been applied to the management of brands (Logman 2004), analysing the relations of cause and effect between the four perspectives of the BSC and subsequently developing a brand management model. Building on the principal ideas of the BSC, we propose to measure the value of place brands via a multi-dimensional approach, which includes the perspectives of the four principal internal stakeholder groups of place brands.

In order to identify and test the performance indicators of place brands for their main internal stakeholders, we use the Sud de France branding case in the Languedoc-Roussillon region.

\subsection{Methodology}

The brand was launched in 2006 by the former president of the region Languedoc-Roussillon, Georges Frêche, with the objective to increase the awareness of the region and to stimulate the sales of local wine and food products, at a time when wine export, in particular, had become threatened due to increased worldwide competition. Very soon, the brand had also been applied to tourism services. In 2013, the brand had 2,600 members, mainly originating from the wine, food and tourism sectors. Apart from its main use to promote local food and tourism, it has also been extended to other domains, such as public regional organisations, infrastructure, cultural and sport events. Approximately 12 million Euros are spent annually for the promotion and communication of the brand. ${ }^{22}$

\footnotetext{
${ }^{22}$ For a detailed case description of Sud de France cf. Chapter 2.
} 
Data has been collected in a stepwise process, using qualitative and quantitative methods.

First, we performed thirteen interviews with several persons from the four above defined internal stakeholder groups in order to identify their expectations of the brand Sud de France: the regional government, local enterprises, consumers and residents (Table 6).

Table 6: Distribution of the interviews

\begin{tabular}{|l|l|l|l|}
\hline & Regional government & Enterprises & Consumers and residents \\
\hline Number & 2 persons & 7 persons & 4 persons \\
\hline Persons & Regional council, & CIVL (Interprofessional & 2 women \\
& Sud de France & Committee of Wines) & 2 men \\
& Development & 1 cooperative & \\
& & 3 food enterprises & \\
& & 1 wine producer & \\
& & 1 tourism service provider & \\
\hline
\end{tabular}

Data from interviews was analysed for each type of actor using content analysis; results of the analysis have allowed us identifying six dimensions of brand value related to the perceived or expected benefits of the four stakeholder groups. The value dimensions have then been operationalised via psychometric scales, combining our own proposed scales with scales from existing literature.

Second, to validate the scales, a questionnaire was developed and performed via an online survey among residents and consumers $(n=207)$, mainly from the Languedoc-Roussillon region. Results of the online survey have been analysed with the statistical software programme SPSS.

\subsection{Results}

\subsubsection{What kind of indicators for place brand value?}

The perceived or expected benefits of the different stakeholders are presented per category. They can represent direct effects of marketing and promotional activities (e.g. an increase of the places awareness or image) or more indirect, i.e. outcomes where the brand has been a contributing or stimulating element (e.g. common identity, economic development or protection of local heritage). 
First of all, the stimulation of the local economic development is a core objective of place brands from governmental policy perspective. By enforcing the bargaining position of local economic actors and attracting investors and tourists to a place, jobs can be maintained and/or created and general welfare increased.

"The brand [Sud de France] has two values: an economic one for enterprises, as communication and commercialisation tool; an institutional one that gives value to the region as a whole, by increasing the awareness and creating a common strong identity. This includes an extension of the brand to other sectors" (member of the regional council)

"What food enterprises do expect from the brand is to guarantee their existence, to keep them in the markets. It is important to mention that the food sector successfully resisted the crises in 2008 and 2012. The brand has surely contributed to this fact!" (brand manager)

The second dimension encompasses outcomes directly related to marketing and promotional efforts. On the one hand, it investigates the degree of awareness of the branded territory (recall and recognition, Keller 1993) and its image. On the other hand, it refers to sales and export figures of labelled products, and to the price premium achieved via the brand. The first-named indicators, brand awareness and image, are relevant for all stakeholders and have some influence on the latter's sales and price premium. In particular, a (positive or negative) image of a place and its products can be profitable or detrimental for export. This is largely documented in the country-of-origin literature (Verlegh \& Steenkamp 1999). Direct effects of the brand as sales and profit outcomes are especially interesting for local enterprises and tourism service providers, including other chain-actors as farmers and retailers. Price premium also depends on the willingness of consumers to pay.

"Sud de France makes export easier... the brand is a multiplier. Awareness and image are important factors, as for a long time wines of the Languedoc-Roussillon had a very bad image." (member of the CIVL)

"The brand allows us to enter the international scene." (a firm director)

"The brand value is enormous, given the number of visitors per year, thanks to the promotion of the brand. This allows us to contribute to the regional economy." (a firm director)

"The impact among food distributors was in the beginning $30 \%$ of the sales; now it is between 0 and 7\%, which is not bad considering this time of crises" (brand manager) 
Perceived quality is the key dimension from consumers' perspective. It measures their perception of the value added by the brand to a place and its products and can point to attributes such as quality, taste, health and wellbeing. With regard to a place as a whole, perceived quality can also express historical, political, economic or human dimensions (Jacobsen 2009). Referring to products and services, benefits may either be functional and experiential, i.e. intrinsic, productrelated advantages as quality, taste or health, or symbolic, i.e. attributes related to personal expressions (Keller 1993).

"I think that a regional brand, just as a commercial brand, must first and foremost guarantee a higher quality at product level. Next, it is interesting to know what it can represent at a territorial level." (a resident)

"What I am interested in during my holidays, is to discover the gastronomic, cultural and natural assets of a place. A place brand like Sud de France can be an adequate tool to make visible what a place can offer." (a consumer)

"Quality guarantee of various local products and services, traceability of products and transparency or their production" (a consumer)

Heritage describes the brands' contribution to the protection, preservation or valorisation of natural, cultural and traditional assets. The main assets are: traditional gastronomic recipes, arts and music, historical visiting sites or ecologically sensitive areas. The latter can be valorised and protected by offering and promoting, e.g. eco-touristic concepts via a brand. Heritage is particularly interesting for residents, as it contributes to a better quality of life.

"In my opinion, a place brand can contribute to valorise and protect local heritage and culture, to show people that this is something with a unique value which needs to be maintained." (a resident)

"I find it important that the food production takes place in the region where I live for the following reasons: for the economy, the landscape and the connectedness with the nature that makes it possible to produce food." (a consumer)

Identity for respondents means the capacity of a brand to reinforce or create an affiliation, a common feeling of belonging to a territory. This indicator underlies solidarity and cooperation among brand users. Identity counts mainly for residents and other stakeholders within a territory. However, external consumers may also share this feeling of taking part.

"There is a notion of belonging, sometimes even pride, and satisfaction with the promotion of the economic life of the place." (a resident) 
The network dimension evaluates the extent to which a place brand contributes to coordination and cooperation among local actors. For governments, it will be relevant to have economic activities within a territory coordinated, especially those related to the place brand, in order to keep coherence and control. Cooperation is considered as especially beneficial for enterprises and could be measured by the number and types of contracts and exchanges.

"We want to group brand actors per product category, to create an agri-food family." (brand manager)

"The brand has a positive influence on local cooperation; it has brought together different organisations in the wine sector that didn't communicate before." (a member of the CIVL)

The results from our interviews allow us to identify six value dimensions and their indicators of the place brand related to the four internal stakeholder groups (Table 7); the perceived or expected benefits are expressed with the symbol ' $\mathrm{X}$ '. After our analysis of the results, the most important expected benefits per stakeholder group are presented as $\mathbf{X}$ in bold.

Table 7: The main dimensions of place brand value for different stakeholders

\begin{tabular}{|c|c|c|c|c|}
\hline & Government & Enterprises & Consumers & Residents \\
\hline $\begin{array}{cl}\text { (1) } & \text { Local economic development: } \\
- & \text { Jobs } \\
- & \text { Tourists } \\
- & \text { Investors }\end{array}$ & $\begin{array}{l}\mathbf{X} \\
\mathbf{X} \\
\mathbf{X}\end{array}$ & & & $\mathrm{X}$ \\
\hline $\begin{array}{cl}\text { (2) Direct marketing outcomes: } \\
-\quad \text { Awareness } \\
-\quad \text { Image } \\
-\quad \text { Sales, export } \\
-\quad \text { Price premium } \\
\end{array}$ & $\begin{array}{l}X \\
X \\
X\end{array}$ & $\begin{array}{l}\mathbf{X} \\
\mathbf{X} \\
\mathbf{X} \\
\mathbf{X}\end{array}$ & $\begin{array}{l}X \\
X\end{array}$ & $\begin{array}{l}X \\
X\end{array}$ \\
\hline $\begin{array}{cl}\text { (3) } & \text { Perceived quality: } \\
- & \text { Quality } \\
- & \text { Taste } \\
- & \text { Health } \\
- & \text { Wellbeing }\end{array}$ & & & $\begin{array}{l}\mathbf{X} \\
\mathbf{X} \\
\mathbf{X} \\
\mathbf{X}\end{array}$ & \\
\hline $\begin{aligned} & \text { (4) } \text { Heritage: } \\
&- \text { Nature } \\
&- \text { Culture } \\
&- \text { Tradition } \\
&\end{aligned}$ & & & & $\begin{array}{l}\mathbf{X} \\
\mathbf{X} \\
\mathbf{X}\end{array}$ \\
\hline (5) Identity: & $\mathrm{X}$ & $\mathrm{X}$ & & $\mathbf{X}$ \\
\hline $\begin{array}{cc}\text { (6) } & \text { Network: } \\
- & \text { Coordination } \\
- & \text { Cooperation }\end{array}$ & $\begin{array}{l}\mathbf{X} \\
X\end{array}$ & $\begin{array}{l}X \\
X\end{array}$ & & \\
\hline
\end{tabular}

Source: authors 
Hence, results of the qualitative survey show the importance and the diversity of the perceived or expected benefits by different stakeholder groups with regard to the place brand. We have identified six dimensions of the place brand value. A part from the network dimension and the export volumes which are specific to regional governments and enterprises (cf. Chapter 2 of the thesis), we operationalise the indicators and then test the measurement model among residents and consumers, which appear as the stakeholder group that regroups the most diversified brand expectations. By choosing residents and consumers of the branded products and services, we integrate the expectations of these two stakeholder groups in our measurement model.

\subsubsection{The value of place brands for residents and consumers}

In order to test the measurement model, we have to operationalise the identified brand value indicators via measurement scales. Table 8 shows the proposed items related to the different indicators identified by the qualitative survey. We have added two variables which are generally used within marketing and brand management literature: the attitude towards the brand which is considered as prior to the evaluation of branded products (Czellar 2003) and overall brand equity. Attitude is measured via the scale defined by Broniarczyk and Alba (1994) and comprises three items; overall brand equity is measured via a scale with four items and has already been validated by Yoo and Donthu (2001). For the other variables that are not present in existing marketing literature, we have proposed items in order to operationalise and to measure them among our sample of consumers and residents via the online survey. 
Table 8: List of items to measure place brand value among consumers and residents

\begin{tabular}{|c|c|}
\hline Variables & Items \\
\hline $\begin{array}{l}\text { Awareness and image of the place } \\
\text { created by the brand }\end{array}$ & $\begin{array}{l}\text { The brand Sud de France: } \\
\text { Increases the awareness of the region Languedoc-Roussillon. } \\
\text { Makes the region more visible at national and international level. } \\
\text { Creates a positive image of the region. }\end{array}$ \\
\hline Perceived quality & $\begin{array}{l}\text { The brand Sud de France: } \\
\text { Guarantees the quality of the labelled products. } \\
\text { Expresses the typicality of regional products. } \\
\text { Stands for the people's friendliness of the region. } \\
\text { Stands for the quality of life of the region. } \\
\text { Expresses the specific way of life of the region. } \\
\text { Gives you confidence. }\end{array}$ \\
\hline Creation of a common identity & $\begin{array}{l}\text { The brand Sud de France: } \\
\text { Gives you a feeling of belonging to the region. } \\
\text { Makes you feel closer to the region. } \\
\text { Can be used for different products and services of the region. }\end{array}$ \\
\hline Protection of heritage & $\begin{array}{l}\text { The brand Sud de France: } \\
\text { Valorises the natural environment of the region. } \\
\text { Contributes to protect the nature of the region. } \\
\text { Valorises the tradition and culture of the region. }\end{array}$ \\
\hline $\begin{array}{l}\text { Economic development of the } \\
\text { region }\end{array}$ & $\begin{array}{l}\text { The brand Sud de France: } \\
\text { Helps farmers/enterprises to persist in the markets. } \\
\text { Contributes to maintain or create local employment. } \\
\text { Attracts tourists. } \\
\text { Attracts foreign direct investors. } \\
\text { Creates added value for the region. }\end{array}$ \\
\hline Attitude towards the brand & $\begin{array}{l}\text { I like the brand Sud de France. } \\
\text { I am in favour of the brand Sud de France. } \\
\text { I appreciate the brand Sud de France. }\end{array}$ \\
\hline Overall brand equity & $\begin{array}{l}\text { I would buy the brand Sud de France rather than another brand if } \\
\text { products are similar. } \\
\text { If I find a brand equally good as the brand Sud de France, I still prefer } \\
\text { buying Sud de France. } \\
\text { Between a product of the brand Sud de France and an equal product, I } \\
\text { prefer to buy the product of Sud de France. } \\
\text { If I have to make a choice between the brand Sud de France and } \\
\text { another brand of the same nature, I take Sud de France. }\end{array}$ \\
\hline
\end{tabular}




\section{Validation of the measurement scales}

The sample of 207 consumers who responded to our survey is composed of about $60 \%$ women and $40 \%$ men, of whom $90 \%$ originate from the Languedoc-Roussillon.

Table 9: Reliability of the measurement scales

\begin{tabular}{lccc}
\hline \multicolumn{1}{c}{ Variable } & Average & Standard deviation & Alpha Cronbach \\
\hline Overall brand equity & 3,31 & 0,91 & 0,91 \\
Attitude & 3,64 & 0,75 & 0,88 \\
Image & 3,83 & 0,84 & 0,84 \\
Perceived quality & 3,06 & 0.78 & 0,85 \\
Identity & 3,53 & 0,85 & 0,73 \\
Heritage & 3,22 & 0.87 & 0,81 \\
Development & 3,47 & 0,72 & 0,85 \\
\hline
\end{tabular}

Despite the exploratory character of these scales, we can note a strong reliability confirmed by the Alpha Cronbach values higher than 0,8. Only the variable 'identity' shows a weaker reliability, but still remains acceptable.

Likewise, the Principal Components Analysis of the variable 'perceived quality' incorporates two dimensions: one related to the quality of the products with $37 \%$ of the variance and the other related to the quality of life in the region, with also $37 \%$ of the variance. The variable 'overall brand equity' loaned from Yoo and Donthu (2001) has been used by many authors and has also here demonstrated a strong reliability, exactly like the variable 'attitude'.

As our aim is to evaluate the overall value of the brand, we have explored the relationships between the different variables. These relationships are all significant, which allows to conclude that each variable contributes to the overall value of the brand from the perspective of the consumers and residents (Table 10).

Table 10: Correlation matrix

\begin{tabular}{|c|c|c|c|c|c|c|c|}
\hline & Brand loyalty & Attitude & Perceived quality & Heritage & Development & Image & Identity \\
\hline Overall brand equity & 1 & & & & & & \\
\hline Attitude & $0,691 * *$ & 1 & & & & & \\
\hline Perceived quality & $0,507 * *$ & $0,401 * *$ & 1 & & & & \\
\hline Heritage & $0,409 * *$ & $0,338 * *$ & $0,676^{* *}$ & 1 & & & \\
\hline Development & $0,472 * *$ & $0,429 * *$ & $0,596 * *$ & $0,616^{* *}$ & 1 & & \\
\hline Image & $0,599 * *$ & $0,545^{* *}$ & $0,563 * *$ & $0,552 * *$ & $0,619^{* *}$ & 1 & \\
\hline Identity & $0,561 * *$ & $0,524 * *$ & $0,500 * *$ & $0,410 * *$ & $0,443^{* *}$ & $0,618^{* *}$ & 1 \\
\hline
\end{tabular}


We can also note that the variables proposed in our measurement system are significantly and positively correlated to the dimension 'overall brand equity'. Consequently, one can consider that the proposed measurement model allows approaching different dimensions of place brand value in the same way that 'overall brand equity' does for the two stakeholder groups, being crucial for the success of the place brand: consumers and residents.

\subsection{Discussion: monitoring place brand performances}

By examining the most important expected benefits per stakeholder group, it is possible to frame a satisfaction profile of the brand and to make a diagnostic of the perceived value by these stakeholders. Based on this, the place brand can be monitored in order to optimise its value for the various actors within a territory. Regularly used, the presented measurement scales contribute to establish a real prospective scorecard which allows monitoring and controlling the performance of a place brand (Figure 6).

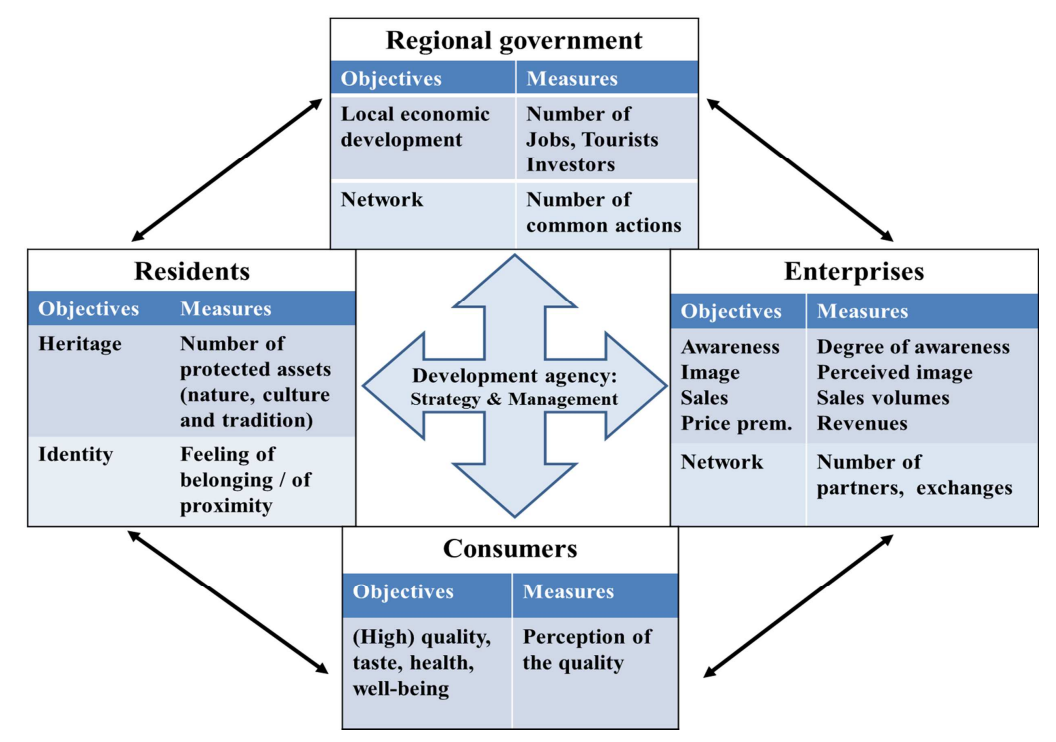

Figure 6: A 'novel' Balanced Scorecard as monitoring tool for the performance of place brands

This proposition is consistent with the evolution that has recently been stated for the utilisation of the BSC (Trébucq 2011). Indeed, if the BSC was in its origin based on the satisfaction of shareholders, it increasingly integrates a more ethical vision sharing values among various stakeholders. This perspective incorporates even the essence of place brands. 


\subsection{Conclusion}

Place branding is not yet a fully developed concept in academic literature, but is greatly used in practice by local authorities. There is a discrepancy between on the one hand the need to legitimise place brands and to know what they can offer for various stakeholders such as governments, enterprises, residents and consumers, and, on the other hand, the absence of an established way to define and measure their benefits. Therefore, we here have stepwise developed a measurement model and monitoring tool for place brand value.

The model was based on the assumption that place brands have specific characteristics, which differ from product brands of companies. Place brands are collective and complex in the sense that they concern a multitude of stakeholders, products and services and target groups. They are in general policy instruments, embedded in a specific socio-cultural and political context. Additionally, they are usually oriented towards long-term success and sustainable development of places. Altogether, this has required a holistic and multi-dimensional approach, including the perspective of different stakeholders.

Via the analysis of the Sud de France case, we have shown that place brands can offer various benefits for different stakeholders at the same time. Apart from their economic value related to the competitiveness of a place and the economic performance of local actors, place brands have the potential to create social and environmental value by valorising and protecting the cultural and natural diversity, creating a common regional identity, and enhancing quality of life. Thus, place brands can contribute to a more sustainable future, especially from a social point of view, regarding identity and cohesiveness, respect and maintenance of traditional values and knowhow, or healthier living environments.

It is here that place branding breaks with traditional views on marketing, providing more than essential options for improved competitiveness. Place branding allows the inclusion of economic, social, cultural and environmental values, a transition from a single entity or stakeholder to a community, from a product to various material and immaterial assets, from an end-user/consumer to a collectivity. It thus changes the paradigm of linear 'chain' thinking into a 'complex system', and short-term ruptures into long-term dynamics. Consequently, one does not deal with a single optimal outcome, but with a landscape of numerous sub-optimal solutions for all dimensions (economic, social, cultural, environmental). 
Reflected by the Balanced Scorecard (BSC), the proposed model may constitute an effective management, monitoring and controlling tool for place brand value. Regularly used, it allows not only for place brand managers to consider and eventually correct the actions of the brand, but also to take joint decisions with different stakeholders involved, and in accordance with their expectations. It can serve to regularly organise workshops with local actors in order to define collectively the positioning and the strategic axes of the brand, and to assure a common vision, and finally to reinforce the relations between stakeholders. Such a participatory, critical and progressive approach will become even more important with the fusion of the regions in France, when territories will change and place brands need to be adapted to new contexts. The participation of citizens in territorial strategic decisions would allow them to assure their contribution to dynamic territorial processes and to the success of place brands. It should be noted that benchmarking with other regions remains necessary, even though the complexity of place brands does not allow direct comparison. This imposes additional reflexions, since the various stakeholders may not have similar background knowledge of other regions.

Our model suffers from certain limits. As Hankinson (2004) recommends, it needs to include in a measurement model the dynamic relations created between different stakeholder groups. Indeed, if the diversity of stakeholders contributes to increase the brand value, the construction of a network of relations between the various actors is equally value-creating. Also, a time dimension should be considered, as various stakeholders are involved differently in the evolution and the exploitation of place brands: their involvement will also impact the other stakeholders in followup phases. The notion of brand value in time thus changes: this should be incorporated in the model. Furthermore, our scales should be validated by a second survey, according to the methods proposed by Churchill (1979) for building psychometric scales. In addition, new local rules and incentives should be tested with regard to the robustness of the model and the behavioural changes of the stakeholders (their arguments and decisions may change). However, this would require an observational study over years, since place brands have long-term consequences and impact. Finally, it would be useful to further test the proposed measurement model with other, successful place brand cases. 


\section{CHAPTER 4}

Place branding, embeddedness and rural development:

Four cases from Europe

Unpublished manuscript: Mechthild Donner, Lummina Horlings, Fatiha Fort, Sietze Vellema 


\section{Chapter 4}

\section{Place branding, embeddedness and rural development: Four cases from Europe}

\section{Summary}

This article investigates the link between place branding and embeddedness for endogenous rural development. It aims to provide insights into how to valorise rural assets via place branding strategies from an endogenous perspective, linking this issue to debates on regional development and (re-)localised food networks. We analyse and compare four regional branding cases exploiting local food and tourism, in order to understand the nature and functioning of place brands. The analysis is based on in-depth interviews with various stakeholders and a review of secondary data. Findings indicate that the following place branding aspects are crucial: the creation of a distinctive territorial identity, the adoption of common values and a joint reflection about brand extensions. All cases show that successful regional branding further depends on the level of embeddedness, i.e. on the ability to stimulate local cooperation, relying on the specific socio-cultural and institutional context. 


\subsection{Introduction: valorising rural assets}

Rural areas are facing severe ecological, social and economic vulnerabilities and competition, embedded in the wider processes of globalisation. Globalisation is the dominant force reshaping rural economies and societies at the start of the $21^{\text {st }}$ century, which has a transformative impact on rural regions (MacDonagh et al. 2015). Globalisation processes have reshaped rural localities worldwide, creating 'the global countryside', which has resulted in entwined ties and interdependencies between different rural areas (MacDonagh et al. 2015, Woods 2007, Woods \& Ramsey 2013), a differentiation of rural space (Marsden 1998, Murdoch et al. 2003), and an ongoing disconnection between farming practices and place which can be considered as a process of 'territorial dis-embedding' (Wiskerke 2007, Wiskerke 2009).

Policies for territorial and regional development emphasise the creation of economic advantage in response to globalisation (Bristow 2010). Regional strategies are littered with the language of 'winning', of gaining some form of competitiveness over other regions (Bristow 2009). The assumption is that regional competitiveness is essential to survive in the new marketplace being forged by globalisation and the rise of new information technologies (Buck et al. 2005).

In this context, rural regions are challenged to valorise their local assets and exploit hitherto unused resources, which is key to the 'new rural paradigm' (OECD 2006). Documents such as the EU Territorial Agenda 2020 (EU 2011), the OECD report Regions Matter (OECD 2009) and the OECD Regional Outlook 2011 Building Resilient Regions mirror the increasing attention for the unique qualities and potential of areas (OECD 2011).

The valorisation of rural assets is central in endogenous rural development (ERD). Endogenous development can contribute to a re-embedding and 're-grounding' of rural practices in territories. This re-grounding takes place at the level where endogeneity, that is "the degree to which a regional economy is grounded on regionally available (and regionally controlled) resources" (Van der Ploeg et al. 2008: 8), can be managed and controlled. Specific (re-)localised networks may be part of endogenous rural strategies.

We would argue that rural sociology debates on endogenous regional development have not been firmly linked with those on localised food networks and on place branding until now. Ray (1998) mentioned that culture can become encapsulated within territories but also the territorial identity itself can be promoted internally and externally. However, it is not clear is how place branding 
strategies exploiting a territorial identity can be linked to the valorisation of food and rural assets in general, in the context of endogenous development trajectories.

Some scholars have begun to address this question. Lee et al. (2005) argued that the region can be marketed 'to itself' as a way of creating social capital, since a stronger sense of shared identity will foster trust and cooperation. The terms 'community' and 'territory' can thus be actively used in rural development to produce a sense of identity. Dessein (2015) suggests that food can be a driver of 'strong territorialisation', which is described as a combination of neo-endogenous development and co-production between society and environment. Others have started from the perspective of cultural economy (Ray 1998), or the creation of new producer-consumer relations (Ilbery \& Maye 2007). A strategy of 'reconnection' practices to place can include new relations between urban places and their rural hinterlands, and new producer-consumer interfaces (Horlings \& Marsden 2014).

This article aims to provide more understanding of the valorisation of rural assets via place branding strategies, leading to rural development. Here, branding is not defined in a narrow sense, as merely the promotion of the marketing of a place, but from a broader endogenous perspective. We refer to Pederson (2004), who considers place branding as constructing territorial ideas, signs and practices and devising new ways for a local society to identify itself.

The central question, then, is how can such strategies be embedded in territorial capital? The notion of territory is not unproblematic. Territory, in English literature, in general refers to territorial settlements and administrative or organisationally bounded areas. However, not all scholars automatically imply the existence of fixed and stable boundaries. Raffestin and Butler (2012) stress its 'relational' dimension. Here we elaborate the French definition of territory as a delimited area which results from a social construction of private and public actors who search for solving a common problem while sharing a common identity (Pecqueur 2001).

In our approach, we compare four European cases of regional branding, in order to understand the nature and functioning of regional brands, to analyse their link to embeddedness, and to review their territorial development outcomes. We highlight generic aspects and specificities of the four marketing strategies, considering pre-conditions, brand management, collective strategies, cooperation forms and kinds of development outcomes. All these criteria are analysed according to the theory of embeddedness and place branding aspects. The article is structured as followed. First, we will position our article in the rural sociology debate on endogenous rural 
development, linking this with the literature on (localised) practices. Then we will draw a literature review on place branding and outline our theoretical framework on embeddedness, describe the methodology used, and finally present our results in terms of a comparison and analysis of the link between regional brands, embeddedness and rural endogenous development. This allows us to come up with some managerial and policy recommendations.

\subsection{Endogenous development and place branding}

Policies aimed at valorising rural assets potentially challenge the conventional agro-industrial dynamic in rural areas, linked to global markets, and large corporations. A rich variety of case studies has explored empirical manifestations of such strategies in various and sometimes interconnected activities, such as alternative food networks, landscape management, the conservation of new nature values and agrotourism (De Roest \& Menghi 2000, Marsden et al. 2000, O’Connor et al. 2006, Renting et al. 2003, Van der Ploeg et al. 2002).

The valorisation of rural assets is central in an endogenous rural development (ERD). As applied in rural sociology, ERD is not synonymous with a discourse of competitiveness, but is considered as development 'from within', increasing the autonomy and self-efficacy of rural areas. It is a "multi-level, multi-actor and multi-faceted process" (Van der Ploeg et al. 2000: 39). On the basis of empirical work, researchers have engaged in a theoretical project to delineate the characteristics of endogenous development (see Marsden 2003, 2006, Marsden \& Sonnino 2005, 2008, Van der Ploeg et al. 2002, Van Der Ploeg \& Renting 2000, Van der Ploeg et al. 2000). The emphasis in most sociological approaches to ERD is in understanding the (natural, human and cultural) characteristics of a place that makes it special and/or distinctive (different from other regions), and how these may become the focus of sustainable economic activity (Vanclay 2011). Endogenous development is based on local resources, control and a redistribution of economic gains (Oostindie et al. 2008). The focus is on a reorientation of activities within the local territory to maximise the retention of benefits by valorising and exploiting local resources, and on the needs, capacities and perspectives of local peoples (Dessein 2015).

Endogenous development does not imply that external or global factors are not important influential factors; rather, these external factors are transformed into a self-constructed model, creating autonomous capacity (Oostindie et al. 2008). Extra-local factors are recognised and regarded as essential, while retaining the belief in the potential of local areas to shape their future 
(Ray 2006). The term neo-endogenous development has been introduced to emphasise the art of balancing exogenous (global) forces and external resources and endogenous resources and local control - thus reducing the vulnerability and exchangeability of rural areas (Ray 2006). (Neo-) endogenous development implies a co-production between humans and their environment, expressed in practices (van der Ploeg \& Marsden 2008), and refers to the interaction of the social and the natural, society and environment, or man and living nature.

Varied regional strategies of re-embedding can be witnessed. While some rural areas develop regional strategies (re-)embedded in contexts of space and place (Horlings \& Marsden 2010 and 2014, Marsden \& Sonnino 2008, Milone \& Ventura 2010, Roep et al. 2015, Wellbrock et al. 2012), others are engaging in a process of 'territorial competition' by using the identity of the region to position themselves (Messely et al. 2009), or seem to lose their regional identity in the globalising economy (Simon et al. 2010). The identification of rural resources (including the physical and social spheres of production) can be combined with new types of marketing strategies that result in externally derived added value to these regionally (re)produced resources (Horlings \& Marsden 2014).

An established literature exists on alternative and re-localised food-products (Tregear et al. 2007). Early research on Alternative Food Networks (AFNs) has widely relied on notions of 'quality', 'trust' and 'place' to characterise this phenomenon as a turn towards the re-localisation and re-socialisation of food (Moragues-Faus \& Sonnino 2012). Debates on re-localised food debates refer to topics such as food-of-origin (Tregear et al. 2007), rural social movements on food sovereignty (Patel 2009, Wittman 2009), urban food policies and planning (Morgan 2009), alternative and civic food networks (Renting et al. 2003) or to the pitfalls of defensive politics of localism (Winter 2003).

In this context, place branding strategies have been developed to link regional identity, rural assets and various practices in food and tourism. A number of European regions have developed a branding strategy based on territorial capital to distinguish themselves from others based on their unique qualities, cultural storylines and the image they communicate. Thus regions become more dependent of their 'cultural load' and of the sense of belonging they are able to create, not only among visitors, but also among entrepreneurs, investors and inhabitants (Horlings 2012). Such branding strategies are increasingly part of the regional public agenda (Pasquinelli 2010, Pedersen 2004). Anholt (2004: 5) stated: "Place branding has the potential to become far more 
than an academic curiosity at the fringes of marketing. Its application to the development and competitiveness of cities, regions and states will have enormous and far-reaching impacts in the years to come." Place branding assumes that the opportunities for rural development depend on the extent to which regions can exploit their assets to create a distinctive identity and can add economic, social-cultural and ecological value to places.

The valorisation and commercialisation of typical regional food products as part of such strategies may be advantageous for local farmers and small and medium enterprises (SMEs) to develop niche strategies within a highly competitive, global market (Stanton 2000). In addition, the assumption is that regional branding is used to reinforce the embeddedness of local actors, to create and exploit strong networks and finally to robustly stimulate the development of territories.

\section{3. $\quad$ Place branding}

The following definitions illustrate the variety in definitions of place branding. Anholt (2004) describes place branding as 'the practice of applying brand strategy and other techniques and disciplines - some deriving from commercial practice and others newly developed - to the economic, social, political and cultural development' of places, emphasizing the tools used in the process. Ashworth, on the other hand, has defined place branding as "the idea of discovering or creating some uniqueness which differentiates one place from others in order to gain a competitive brand value", thereby having a more substantive focus (Ashworth 2009: 10).

In this article, we analyse regional branding strategies which concentrate on local food products and tourism (Boyne et al. 2003, Cohen \& Avieli 2004), a practice which has gained a lot of prominence by governmental policy-makers in the past few years. From reviewing publications from agribusiness literature, it appears that local food products have largely been researched from a consumer perspective (Gracia et al. 2012, Hanf \& Kühl 2005, Loureiro \& McCluskey 2000, Orth \& Firbasová 2003, Roosen et al. 2003, Saito \& Saito 2013, Scarpa et al. 2005, Skaggs et al. 1996), but much less by considering various stakeholders (Wirthgen 2005) or from a strategic management point of view. An exception is presented by Hanf and Kühl (2005) for the branding strategy of the retail.

A regional branding strategy is used to valorise specific local assets. These assets can be tangible (natural, agro-climatic or cultural, patrimonial resources), intangible (skills, know-how, 
traditional recipes, lifestyle) or temporal (historical, e.g. family tradition linked to generations) (Rastoin 2012). Place branding is based on a common understanding of places in terms of the most important attribute(s), so-called 'cultural markers'. The range of markers includes a wide variety of issues, including food, languages and dialects, crafts, folklore, visual arts, drama, literary references, historical and prehistoric sites, landscapes and associated flora and fauna. The invention of a shared regional identity may be just as effective as reassertion of a 'genuine' cultural heritage (Ray 1998). Ideally, place branding strategies mutually strengthen endogenous knowledge and the local territory (Ray 1998), take into account the historical trajectories of social relations in places as well as the contemporary relations which are continuously formed (Kneafsey 2000), and cope with how place is appropriated, articulated and represented by the webs of agents involved in production, circulation, consumption and regulation (Pike 2011). This requires a multi-stakeholder process aimed to develop an 'inner brand' (identity) or connective storyline, developed in collaboration with local groups/stakeholders, which should be distinguished from the 'external' brand (image), the marketing to (and perception by) outside target (consumer) groups (Horlings 2012).

Place branding has been applied to cities, regions or nations (Anholt 2006); it may concern one sector (e.g. food, or even a single chain like wine (Charters et al. 2011), several (e.g. tourism, food, investment) or integrate more or all assets of a delimited territory (see also Dinnie 2004 for an overview). Here we focus on place branding, which is built on the values of a regional territory, its name and (historical) reputation, to enable the promotion and sales of local products and services through joint marketing and quality management, building customer trust. Its main instrument is a collective umbrella brand, which means using the same brand name, identity and logo for several product or service categories. With regard to the food sector, the approach incorporates the French concept of terroir, which links local actors, typical characteristics of agricultural products (quality, taste) and physical assets of a territory like geography, geology and climate (Bérard \& Marchenay 2004, Casabianca et al. 2005).

A challenge of place branding is the creation of a strong common brand identity, which incorporates the core values of the labelled territory and fits into different sectors as well as different product and service categories (Kotler \& Gertner 2002). Other challenges are how to find an appropriate marketing mix (Braun \& Zenker 2010), to keep a coherence of quality within the portfolio of products and services to avoid damaging the brand image (Iversen \& Hem 2008, 
Wernerfelt 1988), and to create a strong governance structure, such as a public-private partnership (Rainisto 2003), and finally how to orchestrate the cooperation between different actors (Therkelsen \& Halkier 2004).

In the cases of regional branding presented in this article, we take into account how regional brands face these challenges. As place branding is based on territory-related identities and values, as well as on specific governance and multi-stakeholder cooperation models, we establish a link to the socio-economic concept of embeddedness.

\subsection{Branding and embeddedness}

There are different meanings of embeddedness, therefore it has been characterised as a "confusingly polyvalent concept" (Jessop 2001: 223). In the original sense developed by Polanyi and Maciver (1957), embeddedness describes the economy as related to a social, cultural and institutional context (societal embeddedness). The authors emphasise the historical pathways of economic actors and give embedding an evolutionary character. While Polanyi and Maciver do not connect the concept directly to social networks, a subsequent seminal work on embeddedness by Granovetter (1985) describes relations between individuals or firms as embedded in actual social networks (structural embeddedness) (Granovetter 1985). Both ideas of Polanyi and Granovetter disapprove neoclassical economic thoughts which under-socialise economic behaviour and postulate a dominance of pure market forces. A third dimension of embeddedness, which emerged in line with the new regionalism from the beginning of the 1990s, is linked to a geographical or spatial aspect, considering the extent of an economic actor's anchorage in a particular place (territorial embeddedness) (Hess 2004).

It is interesting to note that the concept of territorial anchorage is also very common in French literature on regional and/or agricultural economics. It is represented either in the concept of terroir for origin-related food products (Casabianca et al. 2005) or in the économie de proximité, which explains the coordination and innovation mechanism of localised production systems (Gilly \& Torre 2000, Pecqueur \& Zimmermann 2004, Rallet \& Torre 2004). Rallet and Torre (2004) link geographical with organisational proximity, i.e. territorial and structural embeddedness. They argue that geographical proximity can indeed facilitate interactions between actors, but intrinsically it is not able to create coordinative action. 
Figure 7, below, is an adapted version of the figure developed by Hess (2004). It illustrates the three dimensions of embeddedness and serves as analytical framework to investigate possible links between embeddedness and regional branding.

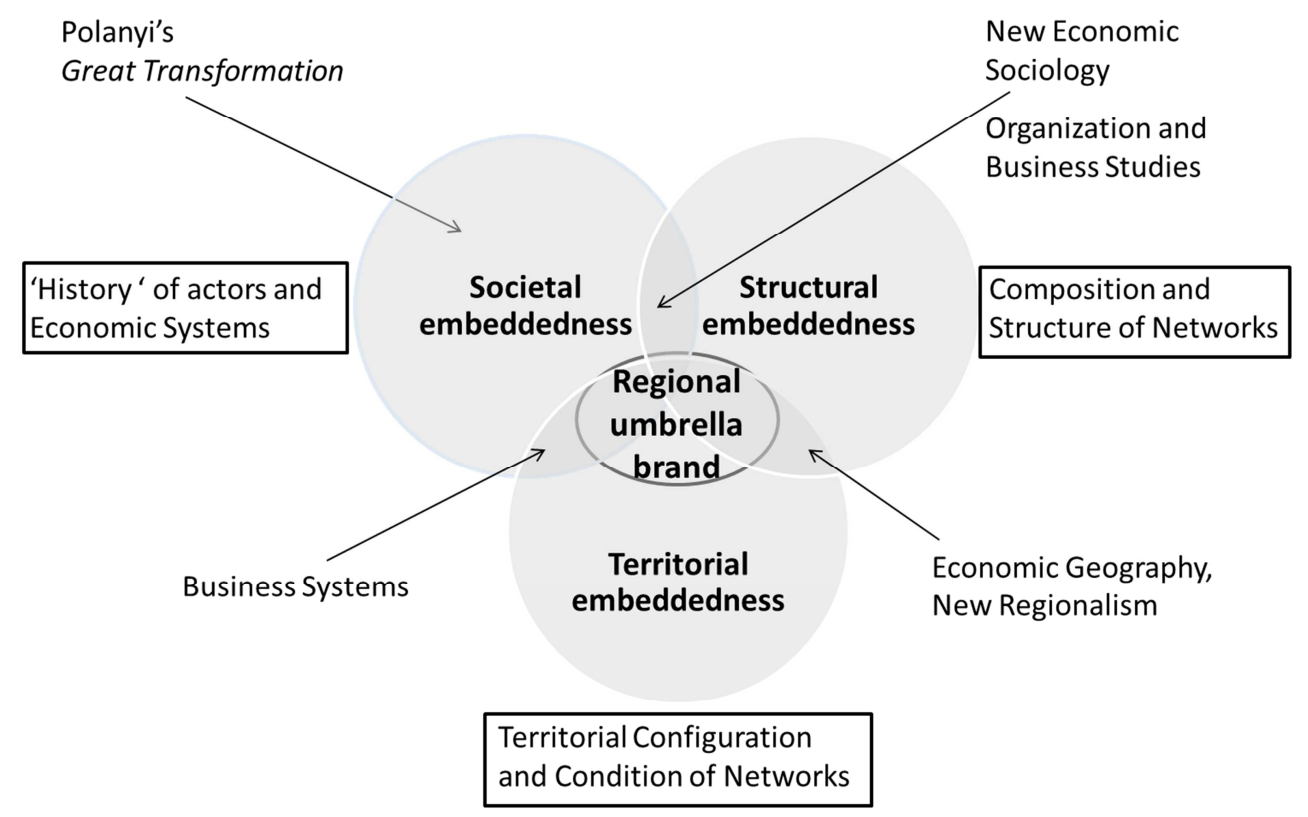

Figure 7: Regional brand linked to embeddedness

Source: Hess (2004), adapted by authors

Analysing regional umbrella brands with regard to the theory of embeddedness seems adequate for several reasons. Bowen (2010) has already shown interrelations between GIs and embedding. However, she highlights the chain aspect of the network, not the regional network. We would argue here that place branding is necessarily linked to different societal aspects, such as historical (cultural heritage), social (collective action), cultural (traditional know-how, origin-linked food products) and political (public policy and governance). Second, place branding is based on interactions between different chains (farmers, processors, retailers, consumers) and non-chain actors (governmental institutions, intermediary organisations). It shows the vertical and horizontal interrelations in a local business system, including cooperation and competition (coopetition), while stimulating the stepwise development of a local network (Halinen \& Törnroos 1998, Uzzi 1996). In this context, the question concerning the role of the state is also important, as it may influence the formal and informal institutional environment in which firms operate 
(Helmsing \& Vellema 2012). Third, place branding also shows the 'dialectical tension between embedding and dis-embedding forces' (Sonnino 2007), i.e. activating local resources for going global. In our view, analysing a series of regional brands and their diverse territorial contexts allows one to demonstrate how collective strategies and cooperation processes, including marketing and sales activities, are connected to local as well as trans-local consumer markets.

The analysis of the following cases is based on criteria which either are related to the concept of embeddedness (pre-conditions, socio-economic, institutional and territorial context, governance structure, funding), to place branding issues (objectives and strategy, brand identity and extension, distribution, product quality, impact) or to both research fields (cooperation, investment).

\subsection{Methodology}

In the past few years, more and more place branding strategies have been developed all over Europe. We selected four cases, two from France (Sud de France and Produit en Bretagne), one from Ireland (A taste of Cork) and one from Germany (Echt Schwarzwald). The first reason for this choice was that France has a long tradition and a lot of experience with the commercialisation of terroir products. The INAO (Institut National de l'Origine et de la Qualité) is the oldest institute for legal food protection in Europe. France has the highest sales value of products with GIs, and French retailers such as Carrefour and Leclerc have, for more than a decade, promoted their own brands for local food such as Reflets de France and Nos régions ont $d u$ talent. The second reason was that the cases from Bretagne and Ireland, being two of the oldest regional initiatives in Europe and already in a mature phase, were considered as good references. Sud de France and Echt Schwarzwald are more recent and have not yet been researched; however, they already revealed new valuable information. 
The methodology used was qualitative in nature, which allows describing and interpreting new or under-researched issues, theory development and policy evaluation and advice (Bitsch 2005). On the one hand, we performed twelve semi-structured, in-depth interviews with public and private key stakeholders between November 2012 and August 2013 for the more recent place branding cases (eight interviews for Sud de France and four for Echt Schwarzwald); for the two older cases we did not conduct our own interviews, as they have already well been researched, and there were also limitations in budget and time. We explored the origin and management of the brands, related problems, and the perceived value added by the brands for the territory and its stakeholders, including network effects. Data was summarised and interpreted according to matching themes (content analysis; Berg 2009). In addition, we collected various secondary data in order to trace the branding processes and their history, such as policy documents, press and academic articles, as well as data from internet sites. Process tracing in social science allows studying decision-making and causal mechanism as well as revealing information about evolutions (Beach \& Pedersen 2013).

The purpose of the comparative case analysis was to develop a deeper understanding of the nature and functioning of regional brands, of how public-private interactions around them are formed and evolve; to explore whether and how territorial and societal embeddedness generate novel partnerships and synergies (structural embedding), and how regional brands can impact rural development.

In order to highlight specific characteristics and challenges for regional brands, and to consider the context in which territorial marketing takes shape, we used literature both from place branding and embeddedness. Neither a pure marketing nor a pure network or sociologic approach was sufficient for analysis. In territorial marketing, the borders of disciplines disappear, requiring a multi-disciplinary approach, from, for example, sociology, history, national identity, and politics (Dinnie 2003), to which we can add innovation and (rural) agribusiness management and even food science and technology related to quality assessment and food safety. 


\subsection{Four cases of regional branding from Europe}

In this chapter, we present the four different European cases of regional branding. We follow a chronologic order, starting with the oldest brand.

\subsubsection{Produit en Bretagne (PeB)}

Produit en Bretagne is one of the oldest regional brands for food in Europe. It has evolved from a difficult economic context. In 1993-1994, Brittany - situated in the North-West of France suffered from a heavy crisis concerning one of its most important sectors, fishery. This went together with the general tendencies of de-industrialisation and de-localisation, giving the habitants a feeling of being marginalised. ${ }^{23}$ As a consequence of this socio-economic context, four entrepreneurs from the Finistère department took the initiative to develop a regional brand in order to keep and create local employment, to enable people living in this territory and to contribute to the regional economic development (hence territorial embeddedness, as discussed later). The collective strategy was from the beginning based on such ethical principles as solidarity and sustainability, inviting consumers to buy responsible, to buy 'Breton'. Such a purchasing incentive was possible as regional identity and solidarity are strongly rooted in Brittany's culture, due to the specific history of the region (societal and territorial embeddedness). In the 2010 report L'Etat Social de la France, realised by the Observatoire du Dialogue et de L'intelligence Sociale (ODIS online document 2010), Brittany was ranking as the second French region regarding social ties linked to economic performance.

The brand PeB soon became institutionalised via an association with the same name, which started with thirteen food enterprises but now has 370 members from many different business activities (44\% from the agri-food sector, but also hotels, restaurants, financial and logistics services, cultural and creative sectors...). ${ }^{24}$ The association constitutes the largest economic network in the region and is still growing. Together with the regional chamber of commerce and industry ,and the higher school of commerce Bretagne Brest, it also successfully created, in 2006, a business incubator, Incubateur Produit en Bretagne (Merieau 2011), which stimulates and supports innovative projects and the creation of new local enterprises (structural embeddedness). It is particularly interesting that the PeB network was the first one to be set up in France by

\footnotetext{
${ }^{23}$ www.produitenbretagne.bzh

${ }^{24}$ Press release of the Produit en Bretagne Association: http://www.lemoci.com/media/produit-en-bretagne
} 
enterprises, not from a public or governmental side. However, the geographical extension from Finistère to other departments within the region has created tensions between brand members, who see their differential advantage threatened with an increasing number of (competing) brand members (Stervinou 2006).

In 2013, about 3,900 different products carry the logo PeB.$^{25}$ While these were, in the beginning, mainly food products, the brand has over time been extended to other product categories (such as typical regional textiles, crafts, books or discs etc.) and various services. If enterprises want to sell products under the brand name, they must be members of the association, respect its values and ethics, and pay an annual contribution fee. They are evaluated via audits by an independent agency, Bureau Veritas. Furthermore, each product is separately checked with regard to its origin and quality before it can be labelled. Concerning distribution, there is a strong interrelation between the association and the regional as well as national retail groups, but also alternative channels are used as bars or restaurants, special boutiques, e-commerce, and also collective restaurants are foreseen.

The outcomes of the brand have been differently explored. Foutrel (2012) asked different involved key stakeholder groups about their meaning of the brand and came to the conclusion that the brand dimensions are going much further than a simple 'made-in' effect, but are centred on employment and solidarity. In 2010, a consumer study was done by TMO, whose results showed that $97 \%$ of the consumers within the region and $49 \%$ in Ile-de-France (Paris) know the brand and that they identify it with its values and commitment for quality, regional employment, economic development, as well as environmental respect. ${ }^{26}$ Moreover, the regional cooperation and network efficiency is considered as a key success of the brand. The capacity to cooperate is in general regarded as the main reason for a higher independency of Bretagne, compared to other French regions: "Brittany is far less dependent from foreign countries than other French regions, and this strong autonomy results from an important density of its regional groups". ${ }^{27}$

\footnotetext{
${ }^{25}$ Baldos (2013), online article in La Croix

${ }^{26} \mathrm{Cf}$. www.produitenbretagne.bzh/les-chiffres-cles and press release: http://www.lemoci.com/media/produit-enbretagne

${ }^{27}$ www.insee.fr/fr/regions/bretagne; translated by the authors
} 


\subsubsection{A taste of West Cork (ToWC)}

The Irish case of regional branding has been documented in detail (O'Reilly 2001, Woods \& Deeganm 2004, Crowley 2004, Dempsey \& O'Reilly 2008, Messely et al. 2010). In 1994, West Cork, a rural agricultural region in the South-West of Ireland, made a bid for financial support from the European LEADER II programme with a positive outcome. Accordingly, the West Cork Leader Co-operative (WCLC) analysed regional strengths and weaknesses (LEADER European Observatory, 1999). It became clear that the area on the one hand had valuable assets such as beautiful and diverse landscapes, friendly hospitable people and food specialties, but on the other hand, there were no cooperative marketing initiatives and only a fragmented services sector (territorial embeddedness). ${ }^{28}$

Therefore, the WCLC decided to promote the region by creating a strong umbrella brand for high quality local food products and tourism services. The main objectives of this strategy were to develop a branded identity and to stimulate collective action by bringing together key stakeholders into a single organisational structure. The Fuchsia Brands Ltd. was set up, incorporating the WCLC, West Cork Tourism, Cork/Kerry Tourism and West Cork Food Producers Association (WCFPA). This organisation was responsible for the brand management and provided infrastructure to network activities of various public agencies and private firms. ${ }^{29}$ Operations of the WCLC were later been taken over by West Cork Development Partnership. ${ }^{30}$

In 1998, the brand was launched commercially for food products (A taste of West Cork) and tourism services (West Cork, a place apart), and was later extended to crafts. The logo carries the typical fuchsia flower, which has a strong association with the region and is easily recognisable. Promotion is done via trade fairs, tourism brochures, media, the publication of a guide showing the best and most typical West Cork products, in-store tasting, etc. The brand is based on high quality and safety, guaranteed through internationally recognised Hazard Analysis and Critical Control Points norms, and reinforced by Fuchsia Brands Ltd. training programmes for product quality, customer care, marketing, food hygiene and safety. Since 2003, a special Fuchsia Retail Affiliate Scheme has been developed, which includes a listing of Fuchsia branded products in qualified, labelled regional retail stores.

\footnotetext{
${ }^{28}$ LEADER European Observatory (online document 1999)

${ }^{29}$ www.westcorkaplaceapart.com

${ }^{30}$ www.wcdp.ie
} 
The West Cork Fuchsia brand has produced a number of positive effects on regional development (Dempsey \& O'Reilly 2008, Ryan et al. 2004, online documents). The results are considered to be related to the European Leader+ programme initiated by the West Cork Leader Co-operative. Among these effects, perceived brand member benefits are increased knowledge (through information and training), a high consumer awareness and positive image of the place, a better market access and stronger cooperation. In addition, the impact study confirms the brand's contribution to the regional economy in terms of total direct value creation, employment rate and multiplier effects on jobs and expenditure within the region. Furthermore, the brand has created a strong territory-based network with inter-sectoral synergies between the food and tourism sector, such as multifunctional agriculture (structural embeddedness). In his case study, O'Reilly (2001) also shows that the institutional support and cultural environment have been key factors for the emergence and identity of the network, as they provide a basis for solidary economic behaviour among enterprises (societal embeddedness).

\subsubsection{Sud de France (SdF)}

The region Languedoc-Roussillon is situated in the South of France and bordered by the Pyrenees Mountains and the Mediterranean Sea; its capital is Montpellier. Geography and culture are deeply contrasting due to different historical origins; the economy is still at the bottom of all French metropolitan regions, with a high percentage of unemployment (13,5\% in 2013). Tourism and agriculture are economic key sectors - Languedoc-Roussillon is the world's largest wine producing region. Compared to Provence or Côte d'Azur, the region has remained for a long time relatively unknown, despite its beautiful landscapes, cultural heritage (such as the Pont du Gard or the city of Carcassonne), and hundreds of kilometres of coast with sandy beaches.

The brand Sud de France was launched in 2006 by the former president of the regional government, Georges Frêche (2004-2010), who strove to bring the region out of its seclusion, activating resources for internationalisation and creating a common identity (societal embeddedness). He initiated the brand together with a new institution for wine professionals, Inter Sud de France, regrouping for the first time all different winemakers of the area (structural embeddedness). Even though SdF was firstly intended to be a common export label for wine producers, which were in crisis due to a worldwide increasing competition, it was extended to other food companies and tourism service providers in 2008. 
The marketing strategy has, since its beginning, had a strong focus on promotion, with enormous advertisement campaigns financed by the regional government - a fact which has been critically regarded. The promoted image is building upon the values of the Mediterranean art of living, as expression of a convivial lifestyle, with authentic, diversified, healthy food and wine. Using the brand is free of charge and entrance criteria are defined in a catalogue of specifications, which until now has not been subject to strict audits. After problems concerning food provenance and quality - leading to dissatisfaction among brand members - product specifications were redefined in 2014 and external quality controls were introduced (interview with a responsible for the agrifood sector of Sud de France Development, on 14 June 2013). Since then, the number of brand members and labelled products from the agrifood sector has considerably decreased (approximately by half). In 2015, Sud de France counted 4,163 registered agricultural and food products from 1,332 member enterprises and 1,100 labelled quality tourism providers. ${ }^{31}$ The brand related activities are coordinated by Sud de France Development, which defines collective strategies for distribution, export and business development. This organisation is financed by the regional government and supported by other public institutions. It plays a strategic role as interface between producers and buyers, principally the big retail groups. In addition, it cooperates with the international Maisons de la Région Languedoc-Roussillon. They are situated in Shanghai, London, Casablanca and New York, and give commercial and logistic support to exporting enterprises in key markets (embedding - dis-embedding).

Regarding the impact of SdF on the development of the region (Donner et al. 2014), a series of in-depth interviews with various public and private stakeholders have revealed two major brand values: an economic one for enterprises, as a communication and commercialisation tool, and an institutional one that gives value to the region as a whole, by increasing its awareness and creating a common identity. This includes an extension of the brand to other sectors, such as logistics, research, sport and culture (interview with a member of the regional council, on 7 February 2013). An indicator for the attractiveness of the brand was also the constantly growing number of brand members. However, this increase was most probably also due to the fact that access to public support was only possible if one becomes a brand adherent. There is not yet a formal network among brand adherents: exchanges are rather informal and take place during common sales and promotional activities (structural embeddedness).

\footnotetext{
${ }^{31}$ Press release 2015: http://www.sud-de-france.com/wp-content/uploads/2015/06/DP-sud-de-france_DOSSIER.pdf
} 


\subsubsection{Echt Schwarzwald (ES)}

The brand Echt Schwarzwald ${ }^{32}$ was initiated in 2006 by the Naturpark Schwarzwald Mitte/Nord, which is situated in the South-West of Germany and belongs to the Bundesland BadenWürttemberg. Covering an area of $3,750 \mathrm{~km}^{2}$, this natural park is the largest one in Germany. The typical Black Forest (Schwarzwald) landscape is diversified, with deep valleys, rivers, grassland and pastures with animals, and dark mixed forest with the typical white fir. A key feature, furthermore, is the alternation between natural and cultivated landscape. However, the use of agricultural grazing areas has decreased in a sense that the image of traditional cultural landscape is threatened. This is due to difficult cultivation conditions (e.g. steep hill farming) combined with low incomes for farmers, who are searching for other job opportunities (territorial embeddedness).

In the light of a growing demand among farmers for forestation of unprofitable grassland, the Natural Park, together with the central Ortenau community, started to think about developing a collective strategy to preserve the traditional landscape. The idea was to develop a marketing concept for high quality beef products. This niche strategy should create added value (via price premium) for local farmers to keep grassland farming attractive and profitable (Koch online document 2008). In 2007, the association Echt Schwarzwald e.V. was founded as a steering organisation, coordinating both production and commercialisation. This association now has about 100 members, principally farmers, but also butchers, restaurants, local communities and the two natural parks Schwarzwald Mitte/Nord and Südschwarzwald. With the support of the consulting firm Ecozept, the brand was launched in 2008 and was rapidly extended to other typical local food products. Only extensive cooperation and a public-private partnership made it possible to create and expand the regional marketing project. On the other hand, communication between the different partners was difficult, because of strong discrepancies between consultancy, administrative and an entrepreneurial culture and way of thinking (interview with the project coordinator of Ecozept on 7 August 2013). Another problem was that brand management and financing had to be assigned from the public to the private sector after four years (societal embeddedness). This is why at present, all brand activities are handled by a single chief executive of Echt Schwarzwald e.V., which is not without its financial and managerial risks.

${ }^{32}$ www.echt-schwarzwald.de 
The basket of goods currently comprises mainly beef and beef products, lamb, typical fruit schnapps and liquor, honey, milk and finally also pork products, such as the famous Schwarzwälder Schinken (Protected Geographical Indication since 2010). The brand is related to local tourism in the natural parks, but the promotion is done with a different logo. ES stands for healthy, qualitative and authentic food, guaranteed through high quality requirements and audits for producers. The commercialisation is effected by short distribution channels, preferring local sales at farms, farmer markets, butchers or restaurants, but also by an online shop.

The economic impact of the brand for farmers' incomes is significant, with on average a 10-12\% price premium (interview with the chief executive of Echt Schwarzwald e.V on 5 August 2013) and a $50 \%$ sales increase from 2009 to $2010 .{ }^{33}$ However, one interviewee criticised the fact that the brand does not yet clearly show its ecological value (interview with a restaurant owner on 5 August 2013). Furthermore, cooperation among brand participants is considered to be important and exists (interview with the chief executive), but can be attributed to normal business exchanges rather than directly to the brand: structural embeddedness).

\subsection{Comparison and analysis of the cases}

We first compare the cases with regard to place branding aspects, then discuss the results according to the three dimensions of embeddedness, and finally review the kind of outcomes on rural development.

The objectives of the four cases are somewhat similar: branding aims at supporting regional economic actors (employment, competitiveness, incomes) and local sustainable development (common identity, quality of life, preservation of cultural and natural heritage). All cases follow a niche strategy, based on specific cultural and/or qualitative differentiation and exploiting territorial assets, as landscapes, terroir products, or people's tradition and know-how. Consequently, the brand identities are strongly rooted in territories and their values, highlighting geographic origins and characteristics. In the case of $\mathrm{SdF}$ it is notable that this origin does not correspond to the political, administrative term of the area, Languedoc-Roussillon, but rather profits from positive connotations related to French food and the South, in general associated with Côte d'Azur and Provence.

\footnotetext{
${ }^{33}$ Kuhnert (2011, online document): http://www.schwarzwaelder-bote.de/inhalt.freudenstadt-regionalmarkeverdoppelt-ihren-umsatz.ab0bc9e3-3dab-432f-9820-37a331b55b64.html
} 
In all cases, brand extensions have been performed to cover other products from the territory. They do not appear to be negative for brand images, if they are in congruence with existing brand values and included transparently. However, in two cases, an influx of new brand members has been considered as a threat by existing participants, because of either inconsistency in product quality $(\mathrm{SdF})$ or increased level of internal competition $(\mathrm{PeB})$.

Distribution channels are mainly operating at local level, which may correspond to the predominant consumer's idea of traditional local food linked to short distribution channels. An exception is $\mathrm{SdF}$, which required a global strategy in order to find new markets for its abundant wine production. Since 2011, Brittany has also started to export selected products under the subbrand Bretagne Excellence.

By comparing the cases, we observe that regional branding is, in the first instance, an issue of marketing. The development of a strong brand identity and related values are essential, which incorporate a territorial unique selling proposition. Here, a future challenge will be to differentiate and highlight the uniqueness of a place among an increasing number of competing place brands. In France for example, nearly each region already has developed its own brand. Furthermore, a well-balanced choice of products and services is essential, with possible brand extensions already in mind, whereby originality and coherence of quality are imperative in order to avoid damage to the brand's image.

The question about the role of embeddedness was intended to provide evidence as to how far place brands can be linked to the three dimensions of this concept.

First, regarding societal embeddedness, each case has its origin in a specific socio-cultural, natural, institutional or economic context. All initiatives started as reactions to a concrete threat and not an opportunity - at either an economic (loss of competitiveness, sales decreases due to globalisation: $\mathrm{PdB}, \mathrm{SdF}$ ), social (marginalisation, rural depopulation, brain drain: ToWC), or natural (loss of cultural landscape: ES) level. In three cases, brands were initiated by the institutional side, as a top-down strategy involving different public and private stakeholders. This kind of public developing aid is illustrative for ToWC and SdF; the first was financed by the EU Leader+ programme and the second was created by a local politician using public subsidies. However, PeB was developed bottom-up and is uniquely governed by private entrepreneurs, leading to a strong network. This was feasible within the specific socio-cultural conditions of Brittany, i.e. a territory with a strong regional identity and solidarity among residents. ES is a 
particular case, as the brand was in its infancy supported by public institutions, but after a relatively short while, the responsibility has been handed over to the private sector.

Territorial embeddedness has been defined as the anchorage of economic actors in a particular place. An illustrative example is the creation and management of PeB by local entrepreneurs intended to support their own territory. In a similar way, the founding father of SdF, Georges Frêche, has for a long time advocated his region and its capital, being a political actor with strong economic interests. Furthermore, the spatial aspect of embeddedness becomes evident considering specific territorial determinants for the brands. By this we mean e.g. the traditional landscape in the Black Forest, the 'friendly character of people in Cork', the Mediterranean atmosphere in the Languedoc-Roussillon and the strong historical independency features of Brittany, which constituted the building blocks for brands.

The third analytical dimension was structural embeddedness, considering the cooperation and network aspects, a kind of emerging outcome preceded by territorial and societal embedding. All cases have shown a need for a leading organisation as orchestrator to ensure various stakeholders' involvement (Echt Schwarzwald e.V., Association PeB, Fuchsia Brands Ltd., SdF Development). The cooperation forms are horizontal and transversal; they all include chain and non-chain actors, mainly within regional business systems. In all cases, branding results at least in some common activities such as seminars, workshops, trade fairs, platforms, as well as in business agreements between producers and distributors. Thus, creating durable partnerships between various stakeholders is a key element of regional branding, but its strength is a question of time. In the older cases, ToWC and PeB, a regional network has already become more deeply rooted than in the case of ES and SdF.

The analysis of four empirical cases confirms our initial assumption that place brands are linked to the three dimensions of embeddedness. They also show that transitions from one of the dimensions to another can be fluent and even interdependent, thus revealing a kind of blending or continuity pattern. For example, structural embeddedness in two of the cases has been influenced by the societal and/or territorial context (PeB, ToWC). SdF, however, partly building on extraterritorial partnerships, gives an example of dis-embedding forces and a dynamic playing field within a territorial marketing strategy. Altogether, the concept of embeddedness plays a significant role for the governance, financing and cooperation measures of regional brands. They are all influenced by the level of embeddedness, but at the same time can also stimulate it. 
Therefore, we characterise the relation as reciprocal. Table 11 shows an overview of the brands with regard to embeddedness.

Table 11: Overview of the regional brands with regard to embeddedness

\begin{tabular}{|c|c|c|c|c|}
\hline & $\begin{array}{l}\text { Produit en Bretagne } \\
(<1993)\end{array}$ & $\begin{array}{l}\text { A Taste of West Cork } \\
(<1998)\end{array}$ & $\begin{array}{l}\text { Sud de France } \\
(<2006)\end{array}$ & $\begin{array}{l}\text { Echt Schwarzwald } \\
(<2008)\end{array}$ \\
\hline $\begin{array}{l}\text { Origin } \\
\text { (territorial, } \\
\text { societal } \\
\text { embeddedness) }\end{array}$ & $\begin{array}{l}\text { Crisis of fish sector, } \\
\text { de-industrialisation. } \\
\text { Private initiative. }\end{array}$ & $\begin{array}{l}\text { Bid for LEADER II } \\
\text { funding. } \\
\text { Public initiative. }\end{array}$ & $\begin{array}{l}\text { Crisis of the wine sector, due } \\
\text { to worldwide competition. } \\
\text { Public initiative. }\end{array}$ & $\begin{array}{l}\text { Need for protection of } \\
\text { cultural landscape. } \\
\text { Public initiative. }\end{array}$ \\
\hline $\begin{array}{l}\text { Funding } \\
\text { (societal } \\
\text { embeddedness) }\end{array}$ & $\begin{array}{l}85 \% \text { private funding by } \\
\text { members' contributions, } \\
15 \% \text { public subsidies. }\end{array}$ & $\begin{array}{l}\text { EU LEADER II funding } \\
50 \% \text {; remainder invested } \\
\text { by the private sector. From } \\
2006 \text {, transition to a fee- } \\
\text { paying scheme. }\end{array}$ & $\begin{array}{l}100 \% \text { public funding by the } \\
\text { Languedoc-Roussillon } \\
\text { government. }\end{array}$ & $\begin{array}{l}\text { In the beginning } \\
\text { supported by local } \\
\text { communities, currently } \\
\text { financed by participants. }\end{array}$ \\
\hline $\begin{array}{l}\text { Brand } \\
\text { identity \& } \\
\text { values } \\
\text { (territorial } \\
\text { embeddedness) }\end{array}$ & $\begin{array}{l}\text { Traditional gastronomy, } \\
\text { local know-how. } \\
\text { Values are based on } \\
\text { ethics, solidarity and } \\
\text { strong historical ties. }\end{array}$ & $\begin{array}{l}\text { Clean, unspoiled } \\
\text { environment, friendly } \\
\text { people, and diversity of the } \\
\text { heritage, culture and } \\
\text { landscape. }\end{array}$ & $\begin{array}{l}\text { Mediterranean and convivial } \\
\text { lifestyle, } \\
\text { authentic, tasty and diversified } \\
\text { food and wine. }\end{array}$ & $\begin{array}{l}\text { True (echt) = authenticity. } \\
\text { What is outside } \\
\text { (packaging, logo) should } \\
\text { be inside. } 100 \% \text { regional, } \\
\text { quality and taste. }\end{array}$ \\
\hline $\begin{array}{l}\text { Cooperation } \\
\text { (structural } \\
\text { embeddedness) } \\
\text { \& effects }\end{array}$ & $\begin{array}{l}\text { Largest economic } \\
\text { network of the region. } \\
\text { Consumer studies show } \\
\text { high brand awareness. }\end{array}$ & $\begin{array}{l}\text { Strategic cooperation } \\
\text { between tourism and food. } \\
\text { Better access to markets. } \\
\text { Improved use of natural } \\
\text { resources. } \\
\text { Increased local } \\
\text { employment. }\end{array}$ & $\begin{array}{l}\text { Policy aim to develop a } \\
\text { sustainable network. } \\
\text { Growing number of } \\
\text { participants. } \\
\text { Increased sales. } \\
\text { Better access to export } \\
\text { markets. }\end{array}$ & $\begin{array}{l}\text { No formal network until } \\
\text { now. } \\
\text { Interest from other } \\
\text { countries to learn from } \\
\text { this initiative. } \\
50 \% \text { sales increase from } \\
2009 \text { to } 2010 \text {. }\end{array}$ \\
\hline
\end{tabular}

Source: authors

Finally, reviewing the various outcomes of the brands on rural development, we state that different methods and indicators have been applied for measurement, thus preventing a direct comparative assessment. On the one hand, quantitative studies have shown the level of brand awareness and perception among consumers (PeB, ToWC), increased sales figures (SdF, ES), the employment rate (ToWC), or the added value in financial terms as price premium (ES, PeB, ToWC). On the other hand, qualitative measures have revealed new insights in individual stakeholder opinions (SdF, ES, ToWC), brand effects on knowledge and innovations (PeB, ToWC) and novel networking schemes (ToWC, PeB, SdF). Altogether, results suggest that place brands can have various positive development outcomes; but there remains a need for a consistent method to measure the impact of place brands, especially in terms of qualitative outcomes. 


\subsection{Discussion and conclusions}

Rural areas, challenged by the globalisation and an increased worldwide competitive economy, are obliged to find new strategies to stimulate economic growth, to support local farmers and SMEs and to ensure welfare of the population. Within the rural sociology debate, the endogenous rural development approach highlights the interaction and co-creation between the natural environment, unique territorial resources and capacities of local people. Place branding strategies are increasingly used in Europe to boost regional and rural development, by valorising territorial assets and creating distinctive place identities. These strategies aim at attractiveness and longterm competitiveness of places. The role of typical local food products herein can play an important role as identity markers, expressing a specific culture and way of life.

Until now in rural sociology literature, links between endogenous development, the embeddedness of localised agri-food networks, and place-based or regional competitive branding strategies have not been firmly established. The empirical findings outlined in this article provide a deeper understanding of the nature, governance and effectiveness of regional brands and their role in rural endogenous development, building on the three-dimensional framework of embeddedness by Hess (2004).

The empirical data collected via a benchmark of four different European cases shows that regional branding processes should be interpreted in an integrative manner. These processes are not just about marketing a territory, but also involve the anchorage of place identity (territorial embeddedness) and public-private interaction (societal embeddedness) which may result in new synergies and partnerships (structural embeddedness). It is the continuum of the three dimensions of embeddedness which supports the success of regional brands as development tools.

In detail, the analysis of four cases has demonstrated that several place branding and embeddedness factors are significant for the creation and success of regional brands. The following policy-recommendations can be derived from the empirical analysis.

First of all, as place brands are complex, with positive and negative feedbacks and side effects, the following aspects have to be taken into account: 1) establish a durable, common, strong brand identity and values, based on specific territorial characteristics and evolutions; 2) create a benchmark by reviewing best practices in European regions and integrate these lessons learnt in positioning and development plans; 3 ) reflect on the choice of products and services which stand for continuous quality and originality under one umbrella brand. As the SdF case has shown, a 
quality control scheme is thereby indispensable; 4) consider consumer markets from inside and outside the labelled area (residents, tourists and consumers abroad), this concerns distribution channels, promotion, cultural diversity and habits of target groups, etc.

Second, the extent to which brands are embedded (societal, network and territorial) plays an important role for the governance, financing and cooperative forces of place brands. The relation between brands and embeddedness has emerged to be reciprocal and dynamic: on the one hand, a place brand can stimulate structural, societal and territorial embeddedness; on the other hand, the branding process itself is strongly influenced by societal and territorial embeddedness.

Third, the role of governance is important in the evolution of a place brand, either being driven by a public or private entity. Our cases have shown that the emergence and governance of regional brands is more often related to public organisations, which may allow a wider brand usage due to a stronger financial power. But place brands then also underlie political changes, e.g. the future of the brand SdF is not clear as Languedoc-Roussillon will be merged with the region Midi-Pyrénées from 2016 on. However, in the case where a brand is managed by private economic actors $(\mathrm{PeB})$, the appropriation and the level of involvement of participants in a network are, from its beginning, higher. A governance form consisting of 'a merging of public and private' (Rainisto 2003), and thus actively involving various stakeholders for common decision-making and co-creating brand value, is therefore recommended, and has been acknowledged in the branding literature (Hatch \& Schultz 2010, Kavaratzis 2012).

Finally, there has been no consistent method for measuring the impact of place brands until now. However, individual cases suggest that place brands can have positive effects on rural development. They have the potential to keep and create local employment (ToWC, PeB), to increase sales volumes and prices (ES), to facilitate the export of products (SdF), and to enhance regional identity and consumer awareness of local products and/or services (all cases). In conclusion, they can thus be considered as a useful strategic tool to increase the competitiveness of local actors and to contribute to the quality of life in rural areas. Hence, place branding strategies can offer a solid basis for regional and rural development plans comparable to brand portfolio strategies of companies for their strategic positioning in the long term. This is all the more relevant in the context of the EU Territorial Agenda, and the OECD 'New Rural Paradigm', seeking for a greater resilience and competitiveness of rural areas by, on the one hand building on territorial potential and assets, and on the other hand promoting cross-sector synergies. 


\section{CHAPTER 5}

\section{Co-creating territorial development and cross-sector synergy: A case study of place branding in Chefchaouen, Morocco}

Mechthild Donner, Fatiha Fort, Sietze Vellema

This chapter has been the basis for an article in French submitted to the Revue Canadienne de Science Régionale/Canadian Journal of Regional Science.

M. Donner, F. Fort, S. Vellema: Marketing territorial et développement local ? Le cas de Chefchaouen, Maroc. 


\title{
Chapter 5
}

\section{Co-creating territorial development and cross-sector synergy: A case study of place branding in Chefchaouen, Morocco}

\begin{abstract}
Summary
Place brands appear worldwide as new kind of political tool for local development on different geographical scales. This article explores the potential to create a place brand for cross-sector cooperation and territorial development in a rural area of Morocco via a case study. Results show that successful place branding does not only build on place identity and local assets, but also depends on the macro-environment and viable partnerships. Regional autonomy, political unity, leadership and public-private cooperation are crucial. Morocco offers opportunities for place branding, but until now seems to have been limited by the uncompleted regionalisation and decentralisation process.
\end{abstract}




\subsection{Introduction}

Since the beginning of the 1990s, place brands appear worldwide on different geographical scales (nations, regions, cities). Within an increased competitive economy, places have adopted marketing techniques to attract tourists, companies and skilled people and to find markets for their export products (Kotler \& Gertner 2002). In general, place brands are initiated and financed by governments as tools for the economic, socio-cultural and political development of places. They express an intention to manage places in a more business-like manner, as a new entrepreneurial style of local government and economic development (Kavaratzis 2005). Thus, they are not only a matter of economy, but also strongly linked to public goals and agencies (Bellini et al. 2010). Furthermore, place brands aim at enhancing local cooperation or, conversely, can label existent clusters (Donner et al. 2014, Kasabov \& Sundaram 2013). Place brands reflect a combination of marketing and a public and political management tool. Therefore, the formation and implementation of place brands involves participation of multiple stakeholder groups, such as public organisations, NGOs, enterprises, investors, residents or tourists (Beckman \& Zenker 2012, Hankinson 2004). These stakeholders can then actively engage in the branding process and give their own place brand meaning, instead of being passive groups; the term cocreation fits well in this context (Kavaratzis 2012).

If place brands are applied to rural regions, they generally aim at local (endogenous) development and target key sectors, such as agriculture and/or tourism, by adding value to typical food products, particular landscapes or cultural heritage. Those features, then, are main components for differentiation.

Due to regionalisation processes, decentralisation of power and globalisation, many regions in the world are now responsible for their own development. They are obliged to create a competitive identity and advantage (Kitson et al. 2004, Malecki 2004). At the same time, the importance of regions as drivers for economic development and growth has been widely recognised in theory and practice (Pike et al. 2006, Porter 2003, Scott \& Garofoli 2011). However, a majority of approaches to development concentrate on macro-economic variables and processes, while development not only depends on larger economic factors, but is also strongly influenced by processes taking place 'on the ground', in specific regions (Scott \& Storper 2007). In rural areas, increased mobility, particularly in the form of tourism and leisure, can offer opportunities for development, often combined with agricultural models (Skuras et al. 2006, Zhang et al. 2007). 
Rural development has changed into a "multi-level, multi-actor and multi-facetted process" (Van der Ploeg et al. 2000: 39). The OECD 'New Rural Paradigm' (2006) has shifted from sectors to places and from subsidies to investments in local specificities, thus highlighting the heterogeneity of rural areas (Ward \& Brown 2009). The territorial approach, which is likewise based on the valorisation of unique endogenous resources, includes multi-stakeholder cooperation and aims at increased competitiveness of places in a globalised world (Baudelle et al. 2011).

This article explores the potential to create a place brand for cross-sector cooperation and territorial development in a rural area of Morocco, via a case study of the province Chefchaouen. The specific challenge is to come to a deeper understanding of the meso-level factors, concerning cooperation and territorial governance. The focus on Morocco is motivated by the ongoing regionalisation and decentralisation process started in 1971, and reinforced in 2010, by an 'advanced regionalisation plan', which is supposed to lead to an integrative and sustainable development of the country as a whole. ${ }^{34}$ In particular, sustainable territorial development will be reached via the valorisation of specific place-based assets, the participation of local actors and the reinforcement of the attractiveness and competitiveness of the regions within the context of market liberalisation (Boujrouf \& Hassani 2008, El Ansari 2009). Local resources and heritage then constitute key concepts of endogenous development and a driving force for public-private cooperation (El Ansari 2013). Herein, typical local food products (produits de terroir) play an important role, exposing the influence of the French approaches to territory-based development and regulation (Fauvel \& Vanier 2006, Koop et al. 2010, Landel 2011), as part of new agricultural and rural development policies (Plan Maroc Vert). It is also here that place branding finds its potential applicability.

The article is structured as follows. The next section presents policy frameworks for development in France and Morocco that show the evolving conditions for territorial development and the French influence. Following this, the territorial development approach is linked to the concept of place branding. Then, the methodology and research location are introduced. Next, results in the form of co-creating activities in Chefchaouen are presented, with an emphasis on local governance and cooperation. The article ends with a discussion and conclusion, including implications for policy and further research.

\footnotetext{
${ }^{34} \mathrm{Cf}$. http://www.lemag.ma/Regionalisation-avancee-consecration-des-valeurs-de-la-democratieparticipative_a62489.html.
} 


\subsection{Policy frameworks for development in France and Morocco}

In France and Morocco, three stages or parallel processes of development exist: (1) national, centrally planned approaches; (2) local initiatives driven mainly by private actors such as local associations, NGOs or small enterprises; and (3) territorial development integrating top-down and bottom-up approaches, and based on the valorisation of place-specific identity and endogenous resources.

\subsubsection{France}

Development visions and policies in France can, in general, be classified into three periods, which are briefly presented here.

The first period started with the national policy of Aménagement du territoire, a term that does not have a satisfactory equivalent in English language (Faludi 2004). "The expressions most commonly used are spatial planning and regional policy but these do not reflect the global ambition to reach a harmonious allocation of economic activities" (Chicoye 1992: 411). Aménagement du territoire arose from the critics concerning the high concentration of activities around Paris (Paris et le désert français, Gravier 1947), and as a response to spatial economic imbalances in France. It was implemented as a development policy from the 1960s onwards, and refers to "public action seeking to allocate geographically the population and economic activities, either to homogenize the territories and to accelerate or regulate development, or to improve the territories' position within the game of international competition." 35 Aménagement du territoire implicates a national centralised planning from top-down and includes regulatory or incentive measures. Even if the concept is neither a specific French exception nor an invention, it is notable that no other western country with a liberal or mixed market economy has such a strong involvement of the state authority in its spatial planning politics. The main planning agency is the DATAR (Délégation à l'aménagement du territoire et à l'action régionale), created in 1963 with the mission to "coordinate the actions of the different ministries in the domain of central territorial development' (Balme \& Jouve 1996: 225).

\footnotetext{
${ }^{35}$ Centre d'Études et de Prospective du Ministère de l'Alimentation, de l'Agriculture et de la Pêche (2010: 1) : http://www.agreste.agriculture.gouv.fr/IMG/pdf_AE2030_Politiques_d_amenagement_du_territoire.pdf
} 
However, Aménagement du territoire has undergone important changes over time. While in the beginning, economic objectives were dominant, social and environmental axes were gradually integrated (Pinchemel 1985). With the laws of decentralisation (Loi Deferre 1982 and 1983), the role of the French state has changed, giving progressively more autonomy and financial means to regional and local authorities. Competences are partly shared and contracts for projects between state and regions elaborated, based on co-financing (CPER, Contrats de Plan États-Régions). A more fundamental change in French national development policies took place in the 1990s, with: (1) a number of new laws aiming at sustainable, participatory territorial development and cooperation between local districts (Loi Pasqua 1995, Loi Voynet and Loi Chevènement 1999); (2) the emergence of supranational European policies; and (3) the increasing question of the localisation of enterprises in a global economy (Alvergne \& Taulelle 2002). Also, the nature of interventions was modified: the initial global vision on the territory has been replaced by more 'tailor-made' development measures for multiple and different territories. This can be captured in the term of projet de territoire, defined as a transversal project and strategy based on a territorial diagnostic and visions and elaborated by the territorial actors themselves, i.e. resulting in territorial development. Finally, the role of agriculture in French development policy has become more central, fulfilling new, spatial, social, environmental and recreational landscape functions, above all in the development of rural areas.

The second stage is that of local development, starting in the 1970s. Local development appeared with the first economic (Fordism) crises and can be understood as an alternative model to the classical development approach based on national central planning. Here, local autonomy, subregional dynamics, endogenous and from-below strategies became central. The focus was foremost on economic development and on the role and cooperation of local actors, as well as on the mobilisation of formal and informal networks. Local actors then socially construct their territory, in contrast to the given, historically-administrative delimitated territory (Pecqueur 2001). Also, the influence of the milieu, i.e. the institutional and sociocultural context, was considered as a crucial factor for local development. This new alternative view on development was strongly influenced by international theories such as on community development or on spatial industrial agglomeration (as milieux innovateurs, industrial districts and clusters). The local development approach was incorporated in France in the Local Production Systems (Colletis et al. 1990, Pecqueur 1989), which, from 2004, served as basis for the nation-wide policy implementation of clusters for innovation, the so-called pôles de compétitivité. 
Third, since the middle of the 1990s, the paradigm changes to territorial development, taking into account not only the national, but worldwide competitive environment (Baudelle et al. 2011). The territorial approach aims at making places more competitive and attractive. It introduces new forms of governance via a coordination and cooperation of multiple actors (also the civil society) and includes top-down as well as bottom-up approaches. Governance has been defined as the production of rules by actors to regulate the economic, productive, social etc. system (Angeon \& Houédété 2006). While earlier development approaches sought an optimal allocation of resources, now the identification, creation and valorisation of specific territorial resources (material and immaterial), being different from those of competitors, has become important (Côté 2003, Pecqueur 2000, 2001) Territories, then, are considered as places with their own particular histories and identities. Heritage and local assets are used as elements for cooperation and as drivers for the construction and sustainable development of territories (Francois et al. 2006, Landel \& Senil 2009). Empirical examples are origin-labels, such as GIs for agricultural products. However, transversal strategies such as collective regional branding are also heavily used. The territorial development approach is now incorporated into the French policies of Aménagement $d u$ territoire, and DATAR has also changed its acronym (Délégation interministérielle à l'aménagement du territoire et à l'attractivité régionale).

\subsubsection{Morocco}

Similar to France, the three development approaches (central, local, territorial) can be observed in Morocco (Koop et al. 2010). French visions on development are important with regard to the Maghreb countries, including Morocco, as development policies in these countries have been influenced by French thoughts even since their independence (Fauvel \& Vanier 2006). At a local level, ideas are also transferred via Franco-Moroccan decentralised cooperation projects (Karzazi 2013, Landel 2011).

With independence in 1956, Morocco faced severe economic problems, in the absence of the former foreign capital and investments flows. The country had a strong socio-economic imbalance, as during the French protectorate all industrial development efforts had been concentrated on the coastal axe Casablanca - Rabat - Kenitra, while the inner regions had been neglected (Adidi 2011). Financially supported and stimulated by the International Monetary Fund (IMF) and the World Bank since 1964, new development plans had been elaborated, with the 
intention of liberalising the market, advancing decentralisation and regionalisation, and enforcing sectoral development. However, in practice, these plans remained centralised for a long time and were dominated by administrative and political interests (Adidi 2011, Ballaoui 2009, Koop et al. 2010). Only since the end of the 1990s, did a novel 'philosophy' of development start to gain currency in Morocco, with the creation of a Ministry for Spatial Planning, Environment, Urbanism and Habitat (Ministère de l'Aménagement du Territoire, de l'Environnement, de l'Urbanisme et de l'Habitat). This ministry is represented in the sixteen regions by the so-called Inspections Régionales d'Aménagement du Territoire, together with sixteen Regional Investment Centres and three Development Agencies for the less favoured provinces of the North, South and the East. Since then, development policies have passed from a pure physical-geographical and administrative type of planning to a more territorial and sustainable concept (Adidi 2011).

In addition, political efforts for regionalisation and decentralism were strengthened in 2010 with the 'advanced regionalisation' plan (régionalisation avancée). This plan is based on the insight that a socio-economic development of the country cannot take place without a stronger decisionmaking power at regional level, and without implicating various forces in society. Advanced regionalisation and democratisation is supposed to lead to an integrative and sustainable development of the country. The big challenge for Morocco will still be to close spatial disparities between strong demographic and socio-economic urban centres and peripheral rural, mainly agricultural regions (El Ansari 2009).

Parallel to these national movements, local and endogenous development initiatives from below, mainly driven by local associations, and in cooperation with international, largely French or Spanish NGOs, have appeared since the 1980s. These initiatives often target various sectors, such as education, energy, food and health, and are thus oriented towards direct, local humanitarian aid and solidarity. In contrast with France, local development visions have not had a direct influence on national policies in Morocco (Koop et al. 2010).

Territorial development combining top-down and bottom-up approaches is an interesting option for the Maghreb countries (Koop et al. 2010). The objective to make territories more competitive and attractive, based on specific local resources, and to integrate them into a global economy, is particularly important for Morocco as it has opened its economy. Also, a mobilization and valorisation of specific territorial identities and resources seem to be adequate for the development of rural marginalised areas, as it takes into account local actors and their specific 
sociocultural and endogenous conditions. This strategy is currently followed within the national agricultural development plan (Plan Maroc Vert).

The Green Morocco Plan was launched in 2008. Agriculture constitutes 19\% of the total national gross domestic product (15\% agriculture and $4 \%$ agri-food) and has an employment rate of about $43 \%$ of the total workforce. Especially in rural areas, where poverty is still high, $80 \%$ of the 14 million inhabitants depend on revenue from agriculture. For smallholders in these marginalised zones, the strategy of the PMV consists of collective and cooperating actions for valorising local heritage, more specifically the protection and promotion of traditional territorial food products (produits de terroir) - by means of GIs, as in Europe. In view of an increasing number of free trade agreements, these value-added products are mainly aimed towards export and tourists.

Furthermore, the advancement of the tourism sector is of great importance to territorial development in Morocco. The country has become one of the principal destinations for European tourists and received more than 10 million tourists in $2013-7 \%$ more than in 2012 . With an employment rate of 500,000 people (5\% of the workforce), and a $12 \%$ contribution to the national GDP, tourism represents the second most important sector after agriculture. The tourism development policy in Morocco is currently defined by the national plan Vision 2020, which was launched in 2010 and intends to make the country one of the world top tourist destinations, attracting 20 million tourists per year. ${ }^{36}$ Therefore, several large programmes are jointly developed by the government, the regions and the private sector. Vision 2020 is also considered as key element within the process of regionalisation and for territorial development, as it gives local authorities the power to decide about the conception, management and governance of their specific touristic offerings.

\footnotetext{
${ }^{36} \mathrm{http} / / / \mathrm{www} . \mathrm{maroc} . \mathrm{ma} / \mathrm{fr} / \mathrm{content/tourisme;} \mathrm{http://www.lavieeco.com/news/actualites/tourisme-le-maroc-determine-}$ a-atteindre-les-objectifs-de-la-vision2020-27657.html.
} 


\section{3. $\quad$ Linking public policy to place branding}

In France and Morocco, the policies towards territorial development, involving processes through which different actors in the area achieve social settlements or resolve conflicts and disagreements, emerged more recently, while the central and local axes have a longer history. We have a particular interest in unravelling the processes leading to collaborative behaviours at the territorial or regional level, and to ascertain whether and how these were triggered by the actions around a commercially-oriented instrument: place branding. Insights on place branding originate partly in marketing literature, trying to detect the success factors for making a place brand commercially viable. This may lead to an over-emphasis on place brands as finished products, researched for their potential positive contribution, which fails to relate the emergence and development of a place brand to an analysis of the more tenacious and unpredictable features of multi-stakeholder processes (Kasabov \& Sundaram 2013).

However, the creation of a collective place brand appears as projet de territoire, a transversal project and strategy based on a common vision, and jointly elaborated by the local public and private actors after a critical diagnostic of the strengths and weaknesses of their territory. It reflects a particular territorial governance form with a multi-actor participation and cooperation, which corresponds to the French definition of a territory as a social construct and the multistakeholder approach of place branding. Joint efforts, which may fail, strive to make places more attractive and competitive in a globalised economy. The commercial orientation is reflected in localised initiatives that aim to identify and valorise various specific local resources for differentiation. This may lead to cross-sector synergies, e.g. between agriculture and tourism. This is inherent in place brands as they are umbrella brands, covering a wide range of placespecific assets (a place as a whole with its specific identity, its different products, services etc.). Therefore, an identification and selected choice of specific valuable assets is needed for place branding, and carried out on the basis of a strategic analysis of the territory.

The following analysis of the place branding preconditions and process in Chefchaouen incorporates the marketing perspective developed and tested empirically via four case studies of city branding in Northern Europe and the USA by Rainisto (2003) and Moilanen \& Rainisto (2009). Their framework highlights the evolutionary character of place brands and looks for processes at different action levels: a macro-level representing the larger political, economic and societal context, a meso-level as playing field for organisations, and a micro-level for small 
groups or individuals. Action at the macro-environmental level positions local development within a global marketplace and process coincidences. The micro-level puts emphasis on the behaviour of small groups, or individuals who take practical actions to develop place identity and image and to organise planning groups consisting of individuals such as local officials, external consultancy, or members of the business community. The meso-action level fits our specific interest in describing the interrelations between organisations or larger groups: cooperation between the public and private sector, charismatic individuals or a political party leading the place branding initiative, and agreement and consistency among political parties or decision makers. Table 12 explains the criteria for success or failure in more detail.

Table 12: Framework: factors for success or failure in place branding

\begin{tabular}{|c|c|c|}
\hline Level & Success Factors & Factors that explain success or failure in place branding. \\
\hline \multirow{2}{*}{ 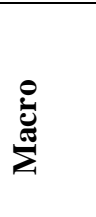 } & $\begin{array}{l}\text { 1. Global marketplace \& } \\
\text { Local development }\end{array}$ & $\begin{array}{l}\text { Global and national competition in international markets. } \\
\text { Attempts for the development of a place to survive in the global marketplace. }\end{array}$ \\
\hline & 2. Process coincidences & $\begin{array}{l}\text { Unexpected happenings in the macro-environment (force majeure), positive or } \\
\text { negative, taking place during and influencing the process. }\end{array}$ \\
\hline \multirow{3}{*}{ 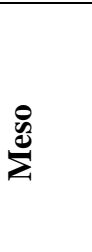 } & 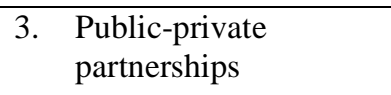 & $\begin{array}{l}\text { Cooperation between the public and private sector; the term governance is } \\
\text { also used. }\end{array}$ \\
\hline & 4. Leadership & Charismatic individual or political party leading the place branding initiative. \\
\hline & 5. Political unity & Agreement, consistency among political parties or decision makers. \\
\hline \multirow{3}{*}{ 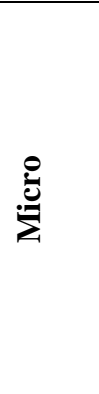 } & 6. Planning Group & $\begin{array}{l}\text { Consisting of individuals such as local officials, external consultancy, } \\
\text { members of the business community, etc. }\end{array}$ \\
\hline & $\begin{array}{l}\text { 7. } \text { Vision \& } \\
\text { Strategic analysis }\end{array}$ & $\begin{array}{l}\text { Vision: insight of the competitive situation and possibilities } \\
\text { Strategic analysis of a place and its different assets worth to be covered by an } \\
\text { umbrella place brand, e.g. SWOT analysis, enabling planning and decisions. }\end{array}$ \\
\hline & $\begin{array}{l}\text { 8. } \\
\text { Place identity \& } \\
\text { Place image }\end{array}$ & $\begin{array}{l}\text { Identity is built on the most unique attraction factor of a place. } \\
\text { Image: perception by the consumers; existing image vs. desired image of a } \\
\text { place. }\end{array}$ \\
\hline
\end{tabular}

Source: adapted from Rainisto (2003)

This paper assesses the preconditions and activities for developing a place brand as a tool for territorial development in Chefchaouen, based on the presented framework. The specific challenge is to come to a deeper understanding of the meso-level factors, concerning cooperation and territorial governance, which are particularly context-specific. 


\subsection{Methodology}

\subsubsection{Case study of territorial development}

As a methodology, an in-depth case study of Chefchaouen in Morocco has already been carried out. It is a case study of a collection of initiatives that work together towards territorial development. It relates these activities to place branding and to the nature of organisation and coordination within the area, as well as to more remote governance processes (in particular the national development plan for agriculture, the Plan Maroc Vert). The case study was done in order to advance practical insights in regional development and in the theory on place branding as a policy tool for territorial development. A case study has been defined as "an intensive study of a single unit - a spatially bounded phenomenon - for the purpose of understanding a larger class of (similar) units" (Gerring 2004: 341). Accordingly, the case study of the province Chefchaouen will enable us to demonstrate the complex process of developing a place brand in a Moroccan region, and to show how local actors come together to cooperate, how they socially construct and develop a territory in this specific context.

\subsubsection{Data collection}

Therefore, events and activities taking place in Morocco and Chefchaouen were identified. Two field visits were undertaken in Chefchaouen by the authors in 2013 and 2014. During the field work, 22 interviews were performed with key stakeholders, such as the mayor of the city Chefchaouen, the director of the agricultural ministry of the province, various non-governmental associations (NGOs), restaurant owners and cooperatives. Eight of these interviews were conducted in detail about a development of a place brand, investigating the general opinion, a potential geographical scale, governance, financing, coordination, marketing mix, and logo. The analysis of interviews was done according to matching themes. Furthermore, network, cooperation and governance issues were paid particular attention, being considered as major determinants for the success or failure of place branding in this area. Here, various initiatives of cooperation were studied (Chaouenrural, Les Restaurateurs Engagés, the cooperatives, the ecotourism strategy by ATED). They were selected, being considered as representative for sectoral and cross-sectoral, as well as for vertical and horizontal cooperation, thus covering a broad spectrum of cooperating activities. 


\subsubsection{Research location}

The province Chefchaouen is situated in the North of the country, in the Rif Mountains, and belongs to the region Tanger-Tetouan. The province is mainly rural, as $90 \%$ of its 435.000 habitants are living in non-urban neighbourhoods, countryside and remote villages. The capital of Chefchaouen is the city of the same name and a unique urban commune with around 36,000 inhabitants. Living standards and infrastructure are highly contrasting between the urban area (the municipality of Chefchaouen) and the 27 rural communes - which are characterised by the culture and people living in the mountains, the Jbala. Also, the administration of the province has changed, as six communes originally belonging to Chefchaouen became part of the neighboured province Ouezzane in 2009. The main economic sectors of the province Chefchaouen are agriculture and, increasingly, tourism. Especially in the past two decades, the town Chefchaouen has become a popular tourist destination, famous for its medina, its surrounding nature, traditional handicrafts and the Mediterranean Diet (label UNESCO for immaterial heritage 2010). As the province has for a long time been excluded from political life in Morocco, due to tensions with the central power of King Hassan II (1961-1999), it has conserved its specific tradition and culture. Some typical agricultural products from the province, such as olive oil, goat's cheese, dried fruits or honey, are foreseen for valorisation and promotion within the PMV. However, as the Rif Mountains constitute the world's largest production area of cannabis, the province also struggles with the negative externalities and image of this cultivation.

A place brand Chefchaouen could be used to valorise and promote typical healthy food and ecotourism services, to stimulate cooperation between local economic actors and to re-brand the area (image enhancement).

\subsection{Co-creation in Chefchaouen}

In this chapter, events and activities in Chefchaouen towards a coherent and collective place brand project are presented as the results of the case study. After giving a more general overview of various events at the three action levels (macro, meso, micro), the chapter shows several examples of cooperating projects at the meso-level. 


\subsubsection{The sequence of events leading to a place branding project in Chefchaouen}

As presented in the framework of Rainisto (2003) above, three levels of activities are important with regard to the creation and success of place brands. Furthermore, these building blocks can be linked to the three territorial development perspectives: (1) the macro-environment to the local global dimension; (2) cooperation and network activities at the meso-level to the territorial governance (social construction of a territory); and (3) activities for place branding at the microlevel to the identification and valorisation of various specific local resources and creation of a unique place identity. Table 13 offers an overview of the dynamic progress of events and activities leading to place branding in Chefchaouen.

Table 13: Time path of the events and activities leading to place branding in Chefchaouen

\begin{tabular}{|c|c|c|c|c|c|c|c|c|c|}
\hline & \multicolumn{2}{|c|}{ Phase 1: 2000 - 2004} & \multicolumn{4}{|c|}{ Phase 2: 2005 - 2009} & \multicolumn{3}{|c|}{ Phase 3: 2010 - 2014} \\
\hline & 2000 & 2004 & 2006 & 20 & & 2009 & 2010 & 2011 & 2012 \\
\hline $\begin{array}{l}\text { Events in the } \\
\text { macro- } \\
\text { environment } \\
\text { (1) }\end{array}$ & $\begin{array}{l}\text { Euro- } \\
\text { Mediterranean } \\
\text { Partnership } \\
\text { program. }\end{array}$ & $\begin{array}{l}\text { US-Morocco } \\
\text { bilateral free- } \\
\text { trade } \\
\text { agreement. }\end{array}$ & & $\begin{array}{l}\text { Nation } \\
\text { Plan } 1 \\
\text { Vert to } \\
\text { develo } \\
\text { agricu } \\
\text { sector. } \\
\text { Legal } \\
\text { frames } \\
\text { for qui } \\
\text { signs C } \\
\text { food } \\
\text { produc }\end{array}$ & & $\begin{array}{l}\text { Economic } \\
\text { crisis has a } \\
\text { negative } \\
\text { impact on } \\
\text { financial } \\
\text { supports \& } \\
\text { tourism. }\end{array}$ & $\begin{array}{l}\text { Advanced } \\
\text { regionalisation plan } \\
\text { (Régionalisation } \\
\text { Avancée). } \\
\text { National plan for } \\
\text { tourism Vision } \\
2020 .\end{array}$ & $\begin{array}{l}\text { Arab spring: } \\
\text { unlike in other } \\
\text { countries, in } \\
\text { Morocco not } \\
\text { leading to a } \\
\text { violent conflict, } \\
\text { but to a } \\
\text { continuation of } \\
\text { internal reforms }\end{array}$ & $\begin{array}{l}\text { EU-Morocco free } \\
\text { trade agreement } \\
\text { for agricultural } \\
\text { products, } \\
\text { followed by } \\
\text { negotiations for a } \\
\text { Free Trade Area. }\end{array}$ \\
\hline $\begin{array}{l}\text { Cooperation } \\
\text { and network } \\
\text { activities at a } \\
\text { meso-level (2) }\end{array}$ & & & $\begin{array}{l}\text { UNESC } \\
\text { recognit } \\
\text { Intercon } \\
\text { Biosphe } \\
\text { reserve, } \\
\text { coopera } \\
\text { Spain. }\end{array}$ & $\begin{array}{l}\text { In as } \\
\text { nental } \\
\text { on with }\end{array}$ & $\begin{array}{l}\text { Crea } \\
\text { Asso } \\
\text { Chac } \\
\text { strat } \\
\text { coop } \\
\text { betw } \\
\text { and }\end{array}$ & $\begin{array}{l}\text { tion of } \\
\text { ciation } \\
\text { ouenrural, } \\
\text { egic } \\
\text { eration } \\
\text { een tourism } \\
\text { agriculture. }\end{array}$ & $\begin{array}{l}\text { Project Les } \\
\text { Restaurateurs } \\
\text { engages; } \\
\text { cooperation } \\
\text { between local } \\
\text { restaurants and } \\
\text { farmers. } \\
\text { Elaboration of a } \\
\text { Tourism Strategy } \\
\text { for the province } \\
\text { Chefchaouen. }\end{array}$ & $\begin{array}{l}\text { Network of the } \\
\text { Communities of } \\
\text { Diet: Chefchaou } \\
\text { Greece, Cilento- } \\
\text { Member of the I } \\
\text { Medinas in the }\end{array}$ & $\begin{array}{l}\text { ur Emblematic } \\
\text { ne Mediterranean } \\
\text { n-Morocco, Koroni- } \\
\text { aly and Soria-Spain. } \\
\text { twork of the } \\
\text { editerranean. }\end{array}$ \\
\hline $\begin{array}{l}\text { Activities at a } \\
\text { micro-level (3) }\end{array}$ & & & & & & & $\begin{array}{l}\text { Label UNESCO for } \\
\text { Chefchaouen as } \\
\text { Emblematic } \\
\text { Community of the } \\
\text { Med. Diet. } \\
\text { Efforts to make } \\
\text { Chefchaouen the } \\
\text { first Eco-city of } \\
\text { Morocco. }\end{array}$ & $\begin{array}{l}\text { Plan to be } \\
\text { recognised by } \\
\text { UNICEF as } \\
\text { Child-Friendly } \\
\text { City. }\end{array}$ & $\begin{array}{l}\text { Elaboration of an } \\
\text { action plan for place } \\
\text { branding of } \\
\text { Chefchaouen by } \\
\text { external } \\
\text { consultancy. }\end{array}$ \\
\hline
\end{tabular}

Source: authors 
Activities for place branding in Chefchaouen at a micro-level included, for example, using a label for the Mediterranean Diet, efforts to label Chefchaouen as an eco-city and as a children-friendly city, and elaborating a business plan for place branding by the external consultancy Diversité \& Développement.

"There are many ideas, but it remains difficult to realise them." (vice-president of ATED, a development association, on 13 June 2014)

Several people were asked about who could lead a branding initiative. Interviews show that there is neither consensus about this issue nor confidence in a specific person or institution to play a leading role.

"It is impossible to manage a brand and to be member of it at the same time, so there is a need for someone who is independent." (vice-president of ATED, on 13 June 2014)

"Someone who knows well this area and the tourism sector." (sales representative of Chaouenrural, association for rural tourism, on 11 June 2014)

"Such an initiative could come from the public side, but must be appropriated from below." (member of an association for local development, ADL, on 12 June 2014)

"This should be initiated by public institutions, later resulting in cooperation between public and private partners." (the mayor of the municipality of Chefchaouen, on 11 June 2014)

"This should be initiated and managed by both public institutions and private sector." (a restaurant owner, on 17 June 2014)

With regard to political unity, obstacles result from the fact that public actors such as the municipality, the provincial council and the ministries have heterogeneous competences and responsibilities. Difficulties appear on the one hand at a level of sectors: a representative for agriculture is present (the director of the DPA, Direction Provinciale d'Agriculture), but one for tourism is missing. On the other hand, the geographical scale presents a problem as the administrative units, i.e. Chefchaouen town and the province, do not correspond with the predominant mountainous culture of the Rif, the Jbala.

"The problem is that each chain has another representative: e.g. the tourism chain has the Ministry of Tourism, the agricultural chain has the DRA and DPA, and then you have the craft chain... It is thus a problem of federation." (project coordinator of the tourism project directed by ATED, 17 June 2014)

"The Moroccan State does not finance anything that isn't directly connected to the PMV. But it could possibly be financed by the Provincial Council." (director of the Direction Provinciale de l'Agriculture, on 13 June 2014) 
"Not only Chefchaouen is important, but Jbala" (rural house owner, on 14 June 2014)

Considering the history of these events and activities, one can note that there is a stepwise evolution, starting at the macro-level, proceeding to the meso- and then to the micro-level. Accordingly, national policies and international agreements may be considered as preliminary for actions undertaken by smaller entities.

\subsubsection{Examples of joint actions building a territorial image of Chefchaouen}

Four different partnerships were investigated: two examples of horizontal (private-private), international and cross-sectoral cooperation (Chaouenrural and Les Restaurateurs Engagés), and two vertical (public-private), sectoral development projects, one for the agricultural sector and one for tourism.

Chaouenrural (www.chaouenrural.org) is an association founded in 2008. It originated from a pilot project lasting from 2003 to 2008, financed by the Spanish ACTLC (Asociación Catalana para el Tiempo Libre y la Cultura) in cooperation with the local association AREA (Association Rif el Andalous pour la protection du patrimoine), with the aim of developing rural tourism in the area of Chefchaouen. Chaouenrural consists of a network of nine rural guest houses, which work together with cooperatives of local food products (produits de terroir) and handicrafts. An information point in the town of Chefchaouen ensures the marketing, sales and logistics of the products and services offered, such as stays in the guest houses, transport, guides, rural touristic or thematic activities, restoration and visits, as well as expositions of the cooperatives. By this, local assets are promoted and intersectoral cooperation and synergies in the form of agro-tourism are stimulated. However, today only three houses still participate and the socio-economic impact of Chaouenrural is quite limited, with tourism offering just a complementary activity for rural house owners, and the tourist flux being restricted to the summer months. In addition, since 2009, the number of tourists at Chaouenrural has considerably decreased (from 903 tourists in 2009 to 475 in 2012), which may be due to the economic crises, but also to the end of the pilot project.

Les Restaurateurs Engagés is a project that was initiated in 2009 by the local association AFHTA Chefchaouen (l'Association pour l'Humain, Terroirs et Alternatives) with the financial support of the French non-governmental organisation GERES (Groupes Energies Renouvelables, 
Environnement et Solidarité). The aim of this initiative is to reinforce the agro-ecological system. The approach consists of valorising local assets by certifying agricultural products and selling them with added-value in local restaurants and guest houses. Short distribution channels are preferred for ecological reasons. In 2014, eleven farmers and six restaurants took part. Although some of the participants are highly dedicated and also involved in other initiatives or networks, the initiative as a whole suffers from an insufficient participation and also from a lack of financial means for marketing. In addition, the financial support of GERES having ended in 2014, the continuation of the project is endangered.

“The financing of this project is already finished." (project coordinator, on 12 June 2014)

"There is no visibility, no marketing, because there is no money for doing that." (idem)

“The restaurant owners don't want to increase prices for their menus." (idem)

"We would like to have more engaged restaurant owners." (engaged restaurant owner, on 16 June 2014)

Public-private partnerships take place within the national PMV, which is performed at regional and provincial level. Here, farmers' cooperatives and unions are created in order to stimulate cooperation, to label territorial products and increase production outcomes. Public support is given in the form of various training programmes with regard to organisational and commercial, plantation and quality issues, and by financial means for infrastructure and material. This year, results of the PMV will be assessed by the number of products per region that have entered in a qualification process for GIs. Interviews in the Chefchaouen province have demonstrated that the national top-down strategy of the PMV is not without barriers. The farmers' motivation to cooperate seems to be limited, as potential benefits are not obvious to them, and distribution continues to take place via conventional channels.

"The idea was not clear in the beginning, and people didn't know what a cooperative was." (member of a cooperative, on 17 June 2014)

"The idea of the Agricultural Ministry developing Geographical Indications is a little bit forced." (member of a union of cooperatives, on 18 June 2014)

"Cooperatives are not motivated to become members of the union; there is no assimilation. They are used to sell directly, in the stores. There is no link between the cooperatives and the union." (member of a union of cooperatives, on 18 June 2014) 
Another example of public-private cooperation is the eco-tourism plan for Chefchaouen. Here, the local association ATED (Association Talassemtane pour l'Environnement et le Développement), in partnership with the Spanish foundation ETEA for cooperation and development and financed by public means of the l'Agencia Española de Cooperación Internacional para el Desarrollo (AECID), has elaborated a tourism strategy for the province Chefchaouen. ATED has brought together various public and private stakeholders, such as members from other local associations ADL - Association de Développement Local, from the municipality, the commune Bab Taza and the private sector. ${ }^{37}$ The complete strategy has been presented to the Commissariat of Tourism in Rabat. It is considered as an exemplary strategy, a pilot project in Morocco, including, amongst other things, the creation of thematic circuits with rural houses in the province, and training for people active in the tourism sector. In addition, several tourism information boards and an information office in Chefchaouen town have been established. However, the office is closed for financial reasons. The tourism strategy for Chefchaouen has until now not been implemented. As the project coordinator explained, this is due to cooperation and federation problems among tourism actors, and above all, to the question of governance.

"Everything has been done to elaborate the tourism strategy, but now, nobody feels responsible for realising this project." (project coordinator of the tourism project directed by ATED, on 17 June 2014)

\subsection{Analysis of the case study}

Results from research demonstrate that Chefchaouen has in general good preconditions and potential for developing a collective place brand.

Rather, the macro-environmental context favours local development within a global marketplace. National policies increasingly give importance to the territorial level via regionalisation and decentralisation, as well as to global exchanges through free-trade agreements and agricultural or tourism development plans.

\footnotetext{
${ }^{37}$ Internal document of the consultancy Diversité \&Développement (2012), Stratégie du Développement du Secteur touristique dans la province de Chefchaouen.
} 
At a micro-level, Chefchaouen has a large number of valuable place-specific material and immaterial assets, such as the medina, an unspoiled nature, typical food, and crafts. Due to its numerous cultural, gastronomic and natural assets, Chefchaouen has become a popular tourist destination. In 2010, the town was recognised by the UNESCO as one of the emblematic communities for the Mediterranean Diet. Furthermore, some typical agricultural products from the province, such as olive oil, goat's cheese, dried fruits and honey, are currently valorised within the national agricultural development plan. The idea of valorising and promoting available assets is omnipresent among stakeholders.

Moreover, at the meso-level, several joint initiatives for building cross-sectoral synergies have been started: on the one hand, there are interactions at a local and small-scale level, such as Chaouenrural, Les Restaurateurs Engagés and the tourism strategy initiated by ATED; on the other hand, there is the large-scale public-private cooperation within the national Plan Maroc Vert, via cooperatives and unions. All these initiatives are exemplary as they demonstrate a beginning of cooperation and coordination for valorising place-based assets at various geographical scales. In addition, the region is engaged in various international (decentralised) cooperation projects, mainly within the Mediterranean. The commitment of local authorities and associations is high.

However, Chefchaouen does not have a place brand. A deeper analysis regarding important context-specific elements for place branding - such as cooperation and partnerships, leadership and political unity - has revealed a number of barriers.

First, cooperating initiatives are often limited in scope: they strongly depend on external support and come to flag if this backing stops. The multiplicity of funds and initiatives by external NGOs or authorities make people continually wait for new development projects and support: they limit their involvement in coherent and collective strategies as place branding.

Second, local actors do not seem to have incorporated benefits and principles of cooperation even less so, if the motivation comes from public side $(P M V)$. However, this engagement of private stakeholders is needed for place branding and territorial development.

Third, there is neither consensus nor confidence in a particular instance that could play the role of a leader. This may be partly due to a general distrust towards public governance forms born from the political history of the country, as the relations between King Hassan II and the Rif area were particularly tense. 
Fourth, the geographical and administrative area of Chefchaouen does not contribute to unify actors for building a place brand. A coherent governance structure is missing in the target region, as fields of competences and responsibilities at sectoral, administrative and geographical level are divergent. Moreover, the different mind-sets and world-views seem to hinder coordinated action between the urban centre and bordering rural districts.

\subsection{Discussion}

Although the concept of place branding has received increased attention in practice and theory in the past two decades, research that focuses on place branding in Africa is sparse, 'almost nonexistent' (Osei \& Gbadamosi 2011). However, the potential and need for branding African countries have been recognised in literature (Anholt 2005, 2006, Calas et al. 2011, Freire 2014, Osei \& Gbadamosi 2011, Wanjiru 2006). Several arguments have been brought forward. First of all, creating single nation brands in Africa could counteract the 'continent brand defect', where the continent is considered as a homogenous mass instead of individual countries (Wanjiru 2006). Each African country is therefore responsible for developing a unique competitive identity (Anholt 2006). Second, place branding then could also contribute to disperse the pessimistic image often associated with the African continent in general - Africa's negative 'halo effect' (Markessenis online document 2009, Osei \& Gbadamosi 2011) - and in return highlight assets and opportunities for export, investment and tourism of single countries. Third, creating strong place brands and enhancing images of developing countries may also be an opportunity to differentiate and add value to their export products and lead to 'protected margins' (Anholt 2005), thus preventing an increasing competition between poor supplier nations going hand in hand with tighter margins. With regard to Africa, several sectors have been identified as business and branding opportunities, such as retail, agriculture, tourism, real estate, sports and manufacturing (Osei \& Gbadamosi 2011). Finally, place branding could be a medium to valorise and promote the rich cultural heritage of places belonging to the African continent, which in total has more than 60 properties recognised by UNESCO as world heritage sites (Calas et al. 2011, Freire 2014). Culture and heritage are not only important cornerstones of places' identities, but also enhance the attractiveness and competitiveness of tourist destinations. 
Within this context of scientific and practical debate of place branding (at national level) in Africa, the contribution of place brands to territorial cooperation and development in Chefchaouen and other Moroccan or African regions would be the following. They could be a way to initiate a new entrepreneurial style of public territorial governance, creating a pro-active political commitment to economic development and enabling multi-actor participation and cooperation. Place brands could also facilitate the embedding of bounded and practical niche initiatives of cross-sector cooperation at a meso-level, collective and coherent projet de territoire; they would then build on specific competences and resources of a defined territory. Furthermore, place brands could contribute to a better articulation of heterogeneous competences and responsibilities at macro- and micro-levels, with emerging signals of territorial governance. In this sense, they would create synergies by defining transversal projects. And finally, place brands could create conditions for bringing together different mind-sets and world-views in urban centres and rural areas, and hence connect the urban with the rural.

\subsection{Conclusion}

Place brands - in order to be efficiently used as local development tools - cannot only build on visions, logos, or places' identity and assets. They must be understood and developed in an integrative, strategic manner, as they are embedded in complex geographical, relational and institutional systems, claiming political guidance and an active commitment from various, interacting public and private stakeholder groups. The performativity of place brands must be seen as an outcome of the way marketing practices gain an institutional fit, with the rules and practices creating commitment and cooperation of various public and private actors towards territorial decision-making power and financial autonomy. Thus, place brands are not just a matter of marketing, but they link public goals with private economic interests. This is important as politicians act within defined geographical areas, addressing certain constituencies.

Another conclusion of the research presented in this paper is that advancing regionalisation and economic development in the food and tourisms sectors in Morocco require novel forms of linking private and public modes of governance and coordination. This could ideally be done in projets de territoire, in joint projects tailored to specific territorial conditions. 
With regard to policy implications, it would be important to further advance and complete the regionalisation process in Morocco, to give local authorities more administrative and financial autonomy and power; and to liberate people from their dependence on external funding and influence by international donors. Furthermore, exchanges between policy makers, place managers and academics, and the already existing decentralised cooperation projects, offer opportunities to obtain a deeper understanding of complex territorial development issues. In any case, further research in other Moroccan regions, and on the role of and need for, international NGOs as donors, should be conducted. 


\section{CHAPTER 6}

Results, discussion and conclusions 


\section{Chapter 6}

\section{Results, discussion and conclusions}

\subsection{Introduction: the aim of the study}

This thesis has been conducted in the framework of the EC financed joint doctoral programme AGTRAIN, whose main topic was 'a successful development and transformation of farming systems in the developing world', with a scope ranging from 'agricultural production, over postharvest management, processing and value-addition to market access and commercialisation'. Herein, the interest of this thesis was to explore place branding as a strategy to collectively valorise, protect and promote various territorial assets and to enhance the market position of local economic actors (including farmers and food SMEs), contributing to agribusiness and territorial development in rural regions, above all in the Mediterranean area (France and Morocco).

As stated in the introduction (Chapter 1), place branding is a multidisciplinary academic concept, without a commonly accepted definition, clear conceptualisation or sound theoretical framework. It has until now predominantly been researched from a market and business perspective and knowledge is mainly based on nation and city branding, while place branding in regions has been rather neglected (Zenker \& Jacobsen 2015). In addition, little is yet known about the conditions and collective processes of place brands, and about their working mechanisms and potential outcomes on agribusiness and territorial development, particularly in an African country.

On the other hand, value-adding and promoting local food products through origin labelling has either largely been approached via studies on GIs concerning single products or via the countryof-origin-effect on consumers; conversely, little research has been done on local food as part of an umbrella place branding strategy for an integrated territorial development, based on crosssectoral cooperation and public-private interaction.

Therefore, the thesis objectives were: (1) to contribute to the scientific debate in the emerging academic field of place branding by clarifying further the concept; (2) - drawing on literature of place branding and marketing management, regional studies and sociology - to understand the conditions, processes and dynamics of place branding in regions, leading to territorial development outcomes; and (3) to gain insights into the concept of place brand value, including possibilities for an assessment. 
The remaining part of Chapter 6 first presents the main findings of the research, answering the research questions. This is followed by a discussion and more general conclusions, considering the implications of the findings on concept and theory, methodology, development policies and place brand management. Finally, the chapter provides suggestions for further research and concludes with some major statements.

\subsection{Main findings}

RQ 1: How does a place brand arise and lead to beneficial outcomes and for whom? How can place brand value be systematically captured and monitored and in what way is value creation impacted by internal and external conditions?

The research began with the study of the regional brand Sud de France (Chapters 2 and 3), which turned out to be a very interesting case, being a political, dynamic and controversial place brand which serves at the same time as a collective territorial brand for food and tourism actors, as well as an institutional brand for public agencies and their objectives.

Sud de France is an example of how a politician acts as institutional entrepreneur and takes a risk by launching a common umbrella place brand instead of direct agricultural subventions, and by bringing together various economic actors from a region, first from the wine sector, but later also from other food chains and sectors (Chapter 2). The study of this initiative has shown that a place brand intended as a collective territorial project can lead to various beneficial outcomes, which can be either quantitative and measurable (the number of brand adherents, sales and export figures related to the brand, degree of satisfaction among enterprises and consumers, etc.) or qualitative in nature (regional awareness, common identity, preservation of diverse local products, enhancement of local cooperation, etc.); hence, for a place brand evaluation, not only the profitability aspect counts. The case has also demonstrated some important working mechanisms and determining factors of a place brand, such as horizontal and vertical relations within the territory, a stepwise involvement, motivation and satisfaction of multiple stakeholders, and a linkage of a place brand with its political, social and economic context. Finally, the analysis of Sud de France has pointed out that for a place brand as a long-term development project, an assessment can follow evaluation logics for public development interventions.

Investigating further what kind of value a place brand can create, and for whom, has resulted in a new measurement model with a set of different value indicators (Chapter 3). This model was 
based on stakeholder theory and on the assumption that defining the value of those brands would need a different measurement approach than that used for commercial brands, due to their specific characteristics being collective, complex, political and long-term oriented. Results have confirmed that various place brand value dimensions coexist, according to the expectations of the four identified key stakeholder groups within a territory: public authorities, enterprises, residents and consumers. These value dimensions include economic, social and environmental indicators. The measurement model has been tested via a survey among residents and consumers. In line with this model, an adapted Balanced Score Card has been proposed which may serve for managing, monitoring and controlling the value of place brands.

RQ 2: What are generic aspects and particularities of place brands? How and why do place brands differ with regard to their origin, management and development? In what way does embeddedness play a role within regional branding processes?

Subsequently, the ambition was to come to a deeper understanding of the origins, processes and more general conditions of place branding applied to regions, via an analysis of four European place branding cases (Chapter 4). Here, it became evident that rural areas in Europe very often make use of place branding strategies based on distinctive identities. By jointly valorising, protecting and promoting their endogenous rural assets (often small-scale agriculture, local food, landscape and eco-tourism), they aim to create value locally and stimulate sustainable place development. These regional brands can be characterised by a high flexibility and variability regarding strategic (e.g. brand extension) and operational marketing issues (marketing mix), governance structure and financing, as well as product or service quality. Thus, one of the advantages of regional branding strategies is that they can be adapted to the specific needs, resources and possibilities of a given place. Another insight was that regional branding processes can only be interpreted in an integrative manner. These processes are not just about marketing a territory, but also involve the anchorage of local actors and place identity (territorial embeddedness), public-private interaction and governance (societal embeddedness), as well as cooperation, synergies and partnerships (structural embeddedness). It is the continuum of the three dimensions of embeddedness that supports the success of regional brands as a development tool. Therefore, the concept of embeddedness provides an adequate analytical framework for understanding and evaluating complex, collective and diverse regional branding processes. 
RQ 3: What are the enabling and constraining conditions for developing a place brand as a collective and cross-sector strategy for territorial development in Chefchaouen, Morocco, and why?

Finally, against the background of several existing European regional branding cases, the aim was to understand whether and under which conditions it would be possible to create a place brand as a collective and coherent territorial development project in Chefchaouen, Morocco (Chapter 5). The case study was conducted at three different action levels: a macro-level, representing the larger political and economic context, a meso-level, concerning cooperation, leadership and political unity, and a micro-level, emphasising the behaviour of small groups or individuals who take practical actions to develop a place identity. Results have demonstrated that conditions are rather favourable at a macro-level, as national policies increasingly give importance to global exchanges via free-trade agreements, to the agricultural or tourism sector via large development plans and to territorial development via regionalisation and decentralisation. Also at a micro-level, great efforts are made in Chefchaouen to valorise endogenous resources (agricultural products, natural parks, the medina, etc.) and to build a distinctive identity. However, a deeper analysis of the meso-level factors concerning cooperation, leadership and political unity has revealed that they are hindering the development of a common place branding project. The initiatives taken at this level are often short term, not coherent with other local projects, and have difficulties reaching scale. In addition, they are mostly stimulated and financed by external, international development organisations. This witnesses the importance of the meso-level cooperating factors in place branding. Another insight gained from the Chefchaouen case was that a place brand could be a useful tool for stimulating cross-sector cooperation and for territorial governance and development in Morocco, but that currently Moroccan regions still lack sufficient autonomy to fully develop their own territorial projects.

\subsection{Conceptualising and theorising collective place brands}

With these main findings from the different case studies, more general conclusions are drawn below and put in accordance with the conceptual diagram and the research objectives as presented in the introduction: (1) to clarify the place branding concept and to shed light in the different types of place brands; (2) to understand the underlying conditions, processes and dynamics of place branding applied to regions; and (3) to gain insights into the concept of place brand value, including possibilities for an assessment. 


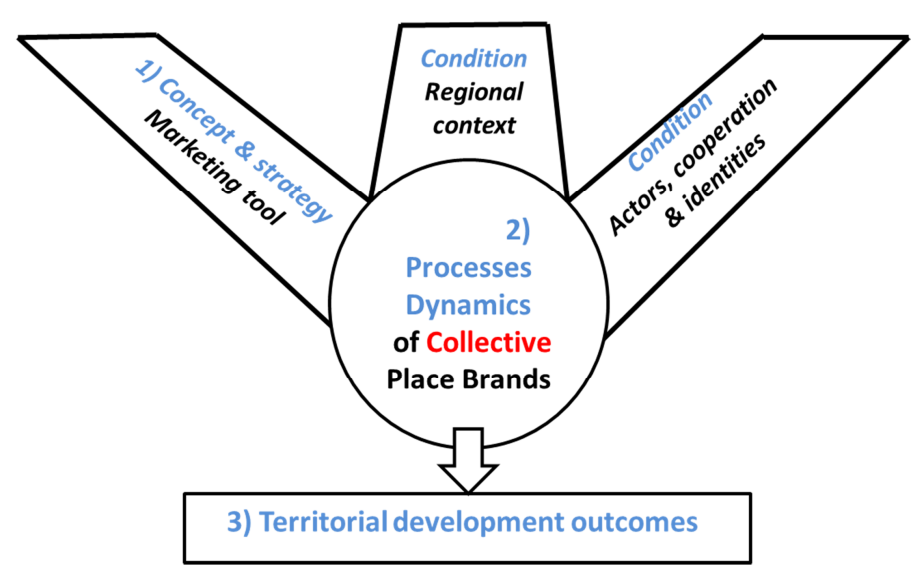

Figure 8: Conclusive conceptual diagram

\subsubsection{The collective place branding concept}

The first objective was to further clarify the rich phenomenon 'place branding' and to shed light on the different types of place brands. Here, the conclusion is that the place branding type that has been explored in this thesis is a distinctive concept, which is collective in nature and can be positioned between two other, rather well-known categories. The first category includes GIs for food products and the second refers to institutional place brands. This conclusion is based on the following argumentation.

In common with GIs, collective place brands rely on the French concept of terroir, which consumers associate with values of natural, authentic, traditional or tasty food. They both aim to create value locally (Chapters 2, 3 and 4), by valorising and promoting typical and quality products of specific territories, guaranteeing their origin and protecting local heritage. Furthermore, collective place branding needs interaction and collaborative processes between private and public entities in order to be successful (Chapters 2, 4 and 5). This is also an important feature of GIs (Fort 2006, Ilbert 2005, Vandecandelaere et al. 2009).

However, collective place brands are different from GIs with regard to their scope and liberty of choice. GIs protect single products, while collective place brands cover a wide range of different food products, as well as tourism or other local products and services. They can achieve aggregation and synergy effects regarding marketing and sales. Thus, collective place brands concern not just a group of actors in a single chain, but multi-clusters with cross-sector synergies. Moreover, GIs are a formal, institutionalised tool, and therefore underlie strict administrative 
procedures, while collective regional brands can be used in a flexible way, enabling various strategies, types of governance and functioning (Chapter 4).

It is important to keep in mind that collective regional brands can be combined with GIs, hence they are complementary. A joint use of a GI and a collective place brand can exploit their respective advantages of having legal protection, a guaranteed price premium, and cooperating structures of single chains on the one hand, and profiting from synergies in the form of sales and marketing and of larger, cross-sector collaborations on the other hand. ${ }^{38}$

In common with the institutional place branding type, collective place brands derive from strategic marketing and branding. They both apply commercial marketing and branding techniques to places in order to develop competitive advantages in a global economy. They mobilise their territorial capital consisting of unique (tangible or intangible) assets and qualities to distinguish themselves from other places via the communication and promotion of a distinctive branded identity. These branding strategies are aimed at an economic, social and cultural place development.

However, while institutional place brands are based on public interventions and governance, collective place brands involve public-private interaction and collaborative processes among various local actors (Chapters 2, 4 and 5). Moreover, in the first case, the right to use the brand is not collective, but in the latter case the brand owner gives the right to use the brand to those who respect the specifications (Chapters 2 and 4 ).

To sum it up, a continuum can be stated: going from (i) one single product, i.e. GIs for food - as a collective, mainly bottom-up approach, which is already well researched in literature - (ii) to the rather uncharted terrain of collective umbrella place branding - as marketing strategy for a basket of local food products linked to other sectors and based on interaction between the public and the private domain - (iii) to institutional place brands - as branding from top-down, concerning public governance, rather well researched.

Table 14, below, offers an overview over the three types of place brands and highlights their main differences.

\footnotetext{
38 A more in-depth reflection about the use of collective place brands as supporting tool for agricultural and territorial development compared to GIs is topic of a forthcoming publication (book chapter): Donner, M., F. Fort and S. Vellema: From Geographical Indications to Collective Regional Branding in France and Morocco.
} 
Table 14: Typology of place brands (with examples from France)

\begin{tabular}{|c|c|c|c|}
\hline & Geographical Indications & Collective place brands & Institutional place brands \\
\hline Ownership & $\begin{array}{l}\text { Owned by the state (as public } \\
\text { good), on behalf of the } \\
\text { producers who govern and use } \\
\text { the GI in conformity with the } \\
\text { established specifications. }\end{array}$ & $\begin{array}{l}\text { The owner of the brand is an } \\
\text { association or a government, } \\
\text { which gives the right to use } \\
\text { the brand to those who respect } \\
\text { the specifications. }\end{array}$ & $\begin{array}{l}\text { The owner is a government, } \\
\text { but the right to use the } \\
\text { brand is not collective. }\end{array}$ \\
\hline Governance & $\begin{array}{l}\text { Mainly the producers } \\
\text { (bottom-up). }\end{array}$ & Various forms possible. & $\begin{array}{l}\text { The institutions } \\
\text { (top-down). }\end{array}$ \\
\hline Objectives & $\begin{array}{l}\text { Legal protection of true origin } \\
\text { of single products to avoid } \\
\text { fraudulent use of the product } \\
\text { name. Price premium for } \\
\text { producers. }\end{array}$ & $\begin{array}{l}\text { Valorisation, promotion and } \\
\text { protection of several place- } \\
\text { specific assets, often quality } \\
\text { (food) products/tourism/ } \\
\text { crafts/natural landscape. }\end{array}$ & $\begin{array}{l}\text { Attraction, competitiveness } \\
\text { and communication of } \\
\text { places. }\end{array}$ \\
\hline Targets & $\begin{array}{l}\text { Mainly export, but GIs can } \\
\text { also target local markets. }\end{array}$ & Residents, tourists, export. & $\begin{array}{l}\text { Investors, immigrants, } \\
\text { tourists and public } \\
\text { institutions. }\end{array}$ \\
\hline $\begin{array}{l}\text { Geographical } \\
\text { scale }\end{array}$ & Established territory. & Region or department. & Nation, region, city. \\
\hline Examples & $\begin{array}{l}\text { Bordeaux wines. } \\
\text { Champagne. } \\
\text { Roquefort cheese. }\end{array}$ & $\begin{array}{l}\text { Produit en Bretagne. } \\
\text { Bravo l'Auvergne. } \\
\text { Le Pays Cathare. } \\
\text { Sud de France. }\end{array}$ & $\begin{array}{l}\text { La Marque Bretagne. } \\
\text { Auvergne Nouveau Monde. } \\
\text { La Marque France } \\
\text { OnlyLyon. } \\
\text { Sud de France. }\end{array}$ \\
\hline $\begin{array}{l}\text { Anchorage in } \\
\text { literature }\end{array}$ & $\begin{array}{l}\text { - Country-of-origin; GIs. } \\
\text { - Origin and quality labelling. } \\
\text { - Food sociology \& } \\
\text { anthropology. } \\
\text { - Food law and regulations. }\end{array}$ & $\begin{array}{l}\text { - Strategic marketing \& } \\
\text { branding. } \\
\text { - Destination branding. } \\
\text { - Country-of-origin. } \\
\text { - Origin and quality labelling. }\end{array}$ & $\begin{array}{l}\text { - Strategic marketing \& } \\
\text { branding. } \\
\text { - Destination branding. } \\
\text { - Nation and city branding. } \\
\text { - Political sciences \& Public } \\
\text { Management. } \\
\text { - Spatial planning. }\end{array}$ \\
\hline
\end{tabular}

Source: author

The features of collective place brands demonstrate that this type of place-based marketing strategy offers considerable flexibility and opportunities. It plays with the material (local products) as well as with the immaterial (the identity of places); it oscillates between quality (labels) and imagination (brands); and it appears in various forms of governance and (chain and territorial) cooperation. Here, it can further be concluded that collective place brands do not only express a modern societal need to act in a more business-like manner, but also imply collective thinking and strategizing. Governing those brands means cooperation between public and private entities that are embedded in the territory. 


\subsubsection{Conditions, dynamics and processes of collective place branding}

The second thesis research objective was to understand the conditions, processes and dynamics of place branding at regional level, leading to territorial development outcomes. Here, a main conclusion is that place brands in regions must be considered as more than a mere marketing and branding tool based on distinctive identity and communicating values. An instrumental (marketing) approach to place brands is important, but not sufficient to fully understand and evaluate them, as place branding in regions are complex and collective processes (at a mesolevel). These processes are highly context-dependent and influenced by their political, (macro-) environmental conditions (Chapters 2-5) and reveal dynamics of the local system (micro-level).

This insight into place branding is rather new, although single aspects have already been covered in literature (cooperating processes of (inter-)regional branding: Therkelsen and Halkier 2009; Pasquinelli 2012; success factors of city branding: Rainisto 2003). This thesis has gone further by considering place brands as both a public-private governance tool (and not exclusively as a political, top-down approach) and a collective territorial development process. A holistic view on place branding in regions including different action levels (micro, meso and macro) being linked to various disciplines is important for understanding and assessing them, even more as regions have very distinct contexts.

Combining (Anglo-Saxon) theories from marketing and management, (French) regional studies and elements from the sociology of food and rural development enabled us to gain a broader understanding and novel (conceptual and theoretical) insights into place branding. This suggests that place branding theory should incorporate theories from different disciplines and even from different cultures rather than focusing on one place branding (marketing) construct. This is necessary for explaining the complex and context-dependent nature, as well as on the outcomes of place branding.

Thus, if place branding in regions is not just about marketing, but is also considered as a collective territorial governance and development project which sets in motion different processes, depends on various, contextual variables, and reveals local dynamics, three main attention points can be implied: (1) territorial embeddedness, i.e. place identity, and the anchorage and dynamics of local actors within their territory; (2) local governance and cooperation as driving processes; and (3) development policies and public interventions, setting the conditions. 
First of all, from the comparison of the four European cases, it became evident that territorial embeddedness plays an important role within collective regional branding initiatives. This was especially the case for Bretagne, where local actors are particularly attached to their place, and thus shared value and historically rooted ties have been crucial to the success of this brand. Furthermore, it was demonstrated that conversely, territorial embeddedness of actors can be stimulated via the adoption of a common branded identity, as in the Sud de France case (or can provoke an opposite, excluding effect, as with the Septimanie brand that had been rejected by the Catalan part of the region). Interestingly, in Chefchaouen, territorial identity and embeddedness were existent, as actors have a strong attachment to their place and many visions on it, but this was not enough for developing a collective place brand. Here, a kind of tension could be observed between the territorial anchorage of local people and the strong influence of extra-local, international organisations. Hence, while territorial embeddedness appeared to be crucial in one case and was a positive side effect in another, it was not a sufficient condition to support a collective place branding project in the third case. Consequently, one can conclude that this micro-level aspect dealing with territorial identity is important for collective place branding, but not exclusively so, as other determinants need to be considered, too.

Secondly, there was no single way of governance leading to successful collective place branding. The different cases have witnessed that many ways exist to develop and manage those brands: from bottom-up (Bretagne) or top-down (Sud de France), or via public-private, mixed forms (Cork, Black Forest). The first form, where the brand came from bottom-up and was principally governed by local economic actors themselves, appeared the most ideal and straightforward way, but is in general difficult to put in place, because of different behavioural patterns of local actors and also because place brands depend on public support and financial means. Therefore, the other place branding cases were issued from public initiatives and had later anticipated a transition scheme. Important for the governance and management of the place brands was in all cases a leading public or private agency.

A significant determinant for the success of collective place branding projects was to bring together different territorial actors and to cooperate, vertically and horizontally, corresponding to a current need to think and act more collectively. This was not taken for granted, but required time, motivation and leadership. It included critical moments, internal competition, differences of opinion and processes of negotiation for consensus-building (e.g. quality level), inclusion and 
exclusion (e.g. products and actors to be included or not) or sometimes resulted in feelings of misunderstanding or discrimination (e.g. due to differences between public administration, consulting firms and business culture), as exemplified in the cases. Cooperation is also linked to the question on how to learn to act collectively, and on how to define common rules. In Chefchaouen, there was predominantly vertical interaction with the nation state or international NGOs, but almost no horizontal cooperation, as local entrepreneurs were either acting individually or according to external initiatives. In this sense, successful collective place branding also necessarily involves an evolutionary (non-linear) and (territorial governance) learning process.

Thirdly, development policies and public support were another context-dependent influencing variable for collective place branding. The brands originated either from a supra-national incentive (the EU LEADER co-funding scheme for rural development in the West Cork branding case), or from a national incentive (the regionalisation and decentralisation processes in France and in Morocco) or from a local incentive (the commitment of local communities in the Black Forest natural landscape protection and therefore in the brand); but they can also be based on an interplay between different geographical scales, as multi-level interventions (e.g. the projets de territoire between the French nation state and its territories).

While in the European cases, a certain degree of political and financial autonomy of the places was given, the decentralisation in Morocco was different and territories did not have sufficient financial autonomy to realise local projects by themselves. Therefore, vertical cooperation with external, (inter)national partners was more effective for people in Chefchaouen than local horizontal cooperation, and a place brand was failing.

It could also be stated that if development tools as brands or GIs are exclusively based on public incentives - as it is the case of institutional place brands in Europe or GIs in Morocco - they can easily fail by missing the important meso-level of cooperation. ${ }^{39}$ It should further be noted that, as the Sud de France case shows, place brands are sensitive to political changes, with changing governments and even changing administrative borders such as the Languedoc-Roussillon being fused with the region Midi-Pyrénées in 2016.

\footnotetext{
${ }^{39}$ An negative example was the brand Montpellier Unlimited, launched by the former president of the agglomeration of Montpellier in 2012 and rapidly cancelled by the new mayor of the city in 2014, after having consumed about 11 million Euros of public money but having principally served for the political auto-promotion of its creator, not for local enterprises and investment as promised.
} 
Hence, development policies and public support are often needed in the context of collective place branding and can also be useful as long as they imply public-private interaction. The timing and kind of support are critical and deserve more attention in place branding in the future. Moreover, public intervention only makes sense if an appropriate assessment is set in place (next section).

\subsubsection{Assessing territorial development outcomes of collective place brands}

A third research objective was to gain insights into the concept of place brand value and, based on this, to develop a framework for assessing territorial development outcomes of place brands. Here, the conclusion is that two aspects need to be considered: (1) the concrete outcomes of collective place brands - in terms of local development effects and the kind of value they can create for territorial stakeholders - but also (2) the multi-level conditions, processes and dynamics leading to these outcomes, that can happen before and during the branding.

Regarding the first aspect, the direct outcomes of collective place brands, the different case studies have revealed that it is not only the economic market value that counts for an evaluation, but that collective place brands can encompass economic, social, cultural and environmental value dimensions. These are quantitative or qualitative in nature and can support territorial and agribusiness development (Chapters 2-5). Thus one does not deal with a single outcome, but rather with multiple (emerging) outcomes that could all be sub-optimal. Another insight was that collective place brands do not have a dyadic producer-consumer relation as with commercial brands, but integrate a whole territorial system, i.e. they can create value for multiple stakeholders. In particular, the investigation of place brand value (Chapter 3), which was based on brand equity and stakeholder theory, has led to a specification of these various potential value dimensions according to different groups. Here, a set of indicators has been established for measuring place brand value. By means of the adapted Balanced Scorecard (Figure 6, p. 66), the value performance could be regularly controlled by brand managers.

Concerning the second aspect, it became evident from this research that assessing collective place brands should also go beyond a measurement of the concrete (marketing) outcomes; but that a broad, multi-level consideration is needed for assessing place brands as collective processes and embedded territorial development projects. The Chefchaouen case has illustrated that there is something happening in a territory before the existence of a brand that needs to be evaluated: a 
collective territorial process, which is an important (pre)condition for the branding success, but complex (concerning different action levels), evolving (changing over time) and contextdependent (depending on individual circumstances). Also, the outcomes of Sud de France (e.g. increased awareness of the region) have been considered in relation to what had occurred before (a heavy crisis of the wine sector and dispersed organisations) and during the branding process (a stepwise convergence of regional activities in the wine, food, tourism and other sectors under this brand). Hence, the tracing of the origins, conditions, dynamics and processes of various individual cases confirms that collective place brands should also be assessed with respect to their development over time which could be at the long-term.

To summarise, assessing collective place brands should embrace a consideration of the branding outcomes themselves as well as the (macro)conditions, (meso-level)processes and (micro)dynamics. This includes an iterative process of both, (1) evaluating various direct outcomes for multiple stakeholders, and (2) evaluating conditions, processes and dynamics at three levels: development policies and public support (macro), governance and cooperation (meso), and territorial identity and embeddedness (micro). As illustrated in the following figure, it is a continuum of these different and context-dependent variables that defines the individual success of collective place brands. This also means that a direct benchmark of different place brands does not make sense even though it may provide valuable insights.

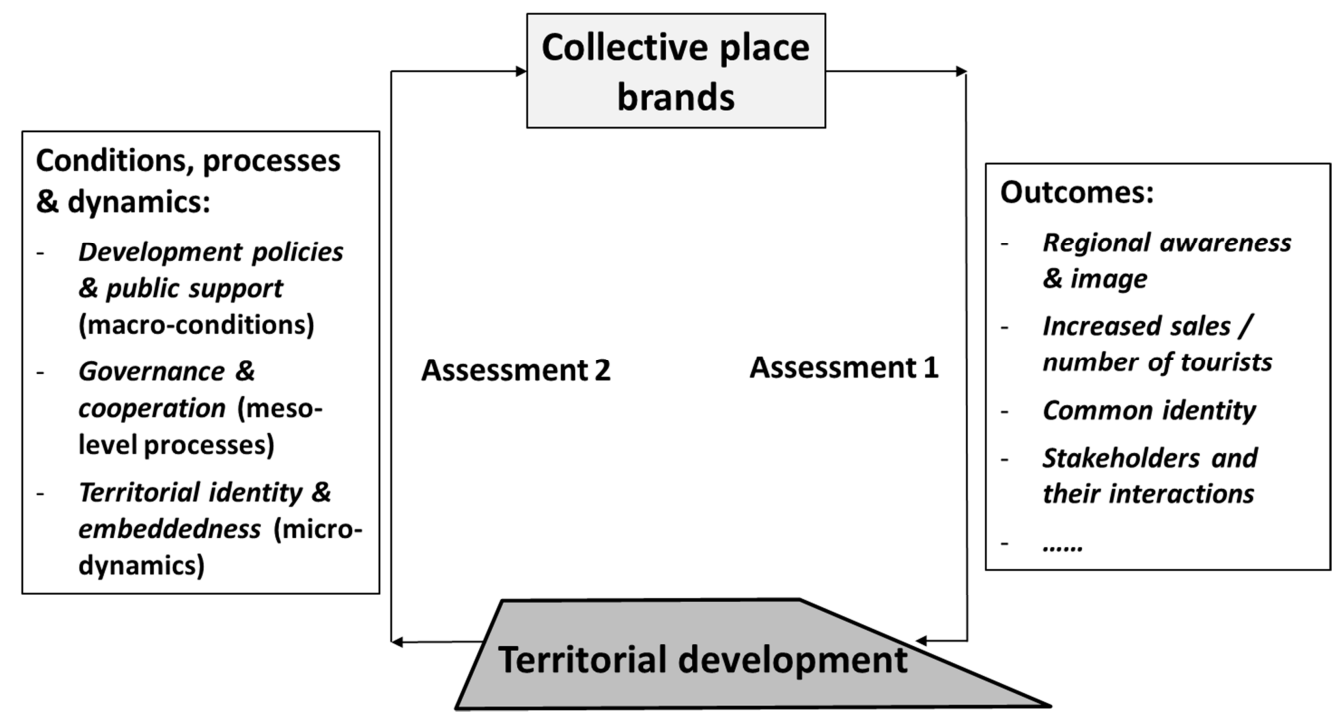

Figure 9: The iterative process of assessing collective place branding outcomes Source: author 


\subsection{Methodological implication: case study approach to collective place brands}

This thesis has emphasised the advantage of using qualitative case studies in order to understand the contemporary and complex phenomenon of place branding. Different types of case study have been used, with different purposes.

The research started with a single case study of the Sud de France brand in order to explore the processes, dynamics and outcomes of a place branding initiative (Chapter 2, an inductive approach aiming at theory-building; Eisenhardt 1989). This was followed by developing and testing a place brand value model derived from management and marketing theory (Chapter 3, deductive approach for theory-testing). Thereafter, an analysis and comparison of multiple European regional branding cases was realised in order to test and confirm causal relations between place branding processes, their conditions and development outcomes, on the basis of the theoretical embeddedness framework guiding the interpretation of the cases (Chapter 4 , deductive approach). Finally, a single explorative case study of Chefchaouen was conducted with different embedded sub-units as a kind of single precursor to a non-existent place brand, in order to gain insights into the conditions and processes for successfully developing a place brand in a Moroccan context (Chapter 5, inductive approach).

Hence, the research design intended to first create very specific knowledge, second to test this knowledge, third to generalise it and fourth to explore the applicability of this knowledge in a new context.

However, using several cases and different case study designs has enabled us to attain depth and breadth at the same time, to reach useful variance within one unit and for several units, and to gain insights into how variables influence each other (Gerring 2004). This implies that case-based research involving both inductive and deductive stages is a useful research strategy for place branding. This also means that case study is the methodology to analyse the context-specific processes and determinants and to assess collective place branding outcomes. 


\subsection{Practical implications for development policies and place brand management}

The implications for development policies and place brand management are derived from the three key findings of this thesis: differentiating between various types of place brands, understanding the conditions, processes and dynamics of place branding and ways of place brand assessment. The following matrix shows the repartition of the implications:

Table 15: Implications of the research findings on development policies and brand management

\begin{tabular}{|c|c|c|c|c|}
\hline Key findings & \multicolumn{2}{|c|}{ Development policy implication } & \multicolumn{2}{|r|}{ Brand management implication } \\
\hline $\begin{array}{l}\text { 1. Different types of place } \\
\text { brands }\end{array}$ & $\mathrm{X}$ & $\begin{array}{l}\text { Evaluate fit with local } \\
\text { development goals }\end{array}$ & $\mathrm{X}$ & $\begin{array}{l}\text { Develop an adequate branding } \\
\text { strategy }\end{array}$ \\
\hline $\begin{array}{l}\text { 2. Conditions, processes \& } \\
\text { dynamics }\end{array}$ & & & & \\
\hline a) Public support & $\mathrm{X}$ & $\begin{array}{l}\text { Define kind and scope of } \\
\text { intervention }\end{array}$ & & \\
\hline a) Collectivity & $\mathrm{X}$ & Define common objectives & $\mathrm{X}$ & Organise common brand activities \\
\hline $\begin{array}{ll}\text { b) } & \text { Territorial } \\
& \text { embeddedness }\end{array}$ & & & $\mathrm{X}$ & $\begin{array}{l}\text { Stimulate a common identity via a } \\
\text { brand }\end{array}$ \\
\hline 3. Assessment & $\mathrm{X}$ & $\begin{array}{l}\text { Assess local processes and } \\
\text { working mechanisms }\end{array}$ & $\mathrm{X}$ & $\begin{array}{l}\text { Measure and control place brand } \\
\text { performance }\end{array}$ \\
\hline
\end{tabular}

From a perspective of policy makers, results from this research can provide clues for efficiently using, supporting and assessing place brands as potential local and agribusiness development tools. First, policy makers have to decide about the kind and scope of public support, i.e. direct support in the form of agricultural subvention (infrastructure, material, training) or indirect in the form of a place brand. Then, they can evaluate whether and which type of place brand (GI, collective brand, institutional brand) fits local development goals, and operates at the adequate geographical level. Accordingly, they will define the form of governance and cooperation. In the case of collective place brands, it has been illustrated that they fit well and can assist the territorial development approach, which is characterised by public-private interaction and a valorisation of various place-specific resources, while considering a competitive environment (Baudelle et al. 2011, Campagne and Pecqueur 2014). For collective place branding, policy makers should then define common objectives together with other public and private stakeholders, in order to reach a win-win situation (co-creation of value). The collective process can be stimulated via information and common discussions. Finally, results suggest that an assessment of place branding from the policy side should, in the first instance, take into account 
local processes and working mechanisms (cooperation and networking, coherence of local activities, local anchorage of actors, and so on).

Results suggest that collective place branding offers real opportunities for policy makers in Morocco. A collective place brand could be a useful governance tool for territorial development in places such as Chefchaouen, as it could combine political interests with economic development and stimulate multi-actor participation and cooperation. A place brand could also join various dispersed initiatives, leading to one coherent and collective territorial development project. Moreover, it could bring together different world-views in urban centres and rural areas via a common identity. However, this will only be possible if Moroccan regions become less dependent on international development organisations and get more local autonomy to fully develop their own territorial projects. In this sense, the existing institutional national brand Terroir du Maroc for various food products may be more adequate than single GIs or collective place brands at regional level at this stage.

From a managerial perspective, this thesis has shown possibilities for implementing, organising and monitoring place brands in a way that they can create benefits for various territorial stakeholders. This starts with developing an adequate branding strategy (identifying valuable place-specific assets and key stakeholders, defining objectives and target groups), in accordance with the type of place brand. In the collective place branding approach, it will be important to exploit or stimulate a common territorial identity via a place brand and to ensure cooperation among different, public and private actors, by organising joint activities among brand members (via workshops, trainings, sales actions, etc.). Finally, measuring the place brand performance could be done via regularly exploring the response profiles to the key stakeholder expectations.

\subsection{Suggestions for further research}

Place branding is not yet based on a sound theory, due to its multidisciplinary and complex nature. Here, a typology of place brands has been proposed and a conceptual framework elaborated to understand and assess complex and collective place branding conditions, processes, dynamics and outcomes. These explorations have revealed new insights in place branding and particularly collective place branding from an agribusiness and territorial development point of view. In particular, this has resulted in a first concept of collective place brands that links management, marketing and regional studies, as well as perspectives from sociology. The latter 
deserves more research attention in the future especially due to a required, better understanding of regional identities. It also has led to the insight that collective place brands are not linear, but iterative processes, which have (positive or negative) impacts on the outcomes, and vice-versa. Hence, collective place brands should be considered as dynamic systems.

While dealing with different disciplines, interacting economic, social, cultural and environmental goals, and a new, non-linear, methodological perspective, the science of complex systems comes into play, because it focuses on the methods of reconstructing the dynamics of heterogeneous systems across traditional domains (Perrot et al. 2015). It may guide one in developing a consistent theory that allows, on the one hand, an understanding of common features of diverse collective place brands and on the other hand, clearly shows differences between them by detecting emergent properties that arise within complex systems.

As a very first attempt to cover the complexity of place branding, a discussion has been initiated with food system modelling experts dealing with complex systems (Perrot et al. 2015). The idea is as follows: collective place branding starts with the notion that one deals with a territory with (or without) clear frontiers (i.e. the playing field), their assets (a diversity of products and services), incentives and restraints, and diverse stakeholders (various public institutions, private parties, individuals). The interactions between diverse stakeholders can be visualised in a twodimensional plot (originating from thermodynamics) revealing an orderly regime, a chaotic regime and the melting zone in between these two (Kauffman 1995). In the melting zone, complex adaptive systems maintain a quasi-equilibrium state; and new emergent properties arise due to self-organisation.

Utilising complex system theories, it would be interesting to further understand the collective place brands discussed here, regarding questions such as: Is the Produit en Bretagne case an example of a self-organised, highly dynamic complex adaptive system, and why? What happens with the dynamics of the Sud de France brand now that the region Languedoc-Roussillon is integrated in another region? Could the collective place brand become highly rigid or chaotic?

The underlying question would here be the following: Can collective place brands be described as complex adaptive systems, with the seven essential properties as described by Carbonara (2010), namely heterogeneous agents (stakeholders, social capital...), melting zone, co-evolution (of stakeholders or groups), self-organisation and emergence (new performance/properties of place brands...), non-linear interactions (of, e.g. agro-tourism), butterfly effects (minor 
perturbations with substantial consequences), and scalability (e.g. for the extension of place brands)?

Another issue that has emerged during this thesis, and which should further be researched, is the interrelations between various place brand stakeholders. In Chapter 3, stakeholder theory from management literature (Freeman 1984, Mitchell et al. 1997) has enabled us to identify various place branding actors and to investigate different brand value dimensions according to their expectations. However, a limitation was that the interrelations between the different actors have not been incorporated (Hankinson 2004). Thus, for collective place branding, (new forms of) management theory should be explored at the interface between the public and private sector.

\subsection{Conclusion}

The focus of this thesis was on place branding processes for agribusiness and territorial development in Mediterranean rural regions. It described and explored various place branding cases in Europe and Morocco with regard to their conditions, processes and dynamics, generating context-dependent territorial development outcomes.

From this thesis research, three main conclusions could be drawn. The first one was that among the different types of place brands that exist, collective place brands are a distinctive concept positioned between GIs on the one hand (sharing the collective character for valorising placespecific resources such as food) and institutional brands on the other hand (as targeted branding strategies applied to places to increase their competitiveness). The second conclusion was that collective place brands in regions do not only rely on territorial identity (micro-dynamics), but also involve public-private interaction and cooperation (meso-processes), and are entangled with their political environment (macro-condition). Third, an assessment of collective place brands should include their direct outcomes, as well as their context-specific conditions, processes and dynamics.

Therefore, place brands for regions must be considered as more than mere marketing instruments, but as dynamic and collective territorial development processes. Then, they may constitute a useful and adequate tool for supporting agribusiness and local development. 


\section{References}

Aaker, D.A. (1991) Managing brand equity (New York: Free Press)

Aaker, D.A. (1996) Managing brand equity across products and markets. California Management Review 38 (3) pp. $102-120$

Aaker, D.A. (2004) Leveraging the corporate brand. California Management Review 46 (3) pp. 6-18

Ackermann, F. and C. Eden (2011) Strategic management of stakeholders: Theory and practice. Long Range Planning 44 (3) pp. 179-196

Adidi, A. (2011) De l'aménagement du territoire au développement territorial : quelle transition et quelle articulation? Contribution to the First Intercontinental Conference of Territorial Intelligence, Gatineau, Canada, October 2011

Alvergne, C. and F. Taulelle (2002) Du local à l'Europe. Les nouvelles politiques d'aménagement du territoire (Paris: PUF)

Anders, S. and J.A. Caswell (2008) The benefits and costs of proliferation of geographical labelling for developing countries. University of Massachusetts Amherst, Department of Resource Economics Working Paper no 7:

http://ageconsearch.umn.edu/bitstream/42130/2/ResEcWorkingPaper2008-7.pdf

Andersson, I. (2014) Placing place branding: an analysis of an emerging research field in human geography. Geografisk Tidsskrift-Danish Journal of Geography 114 (2) pp. 143-155

Angeon, V. and T. Houédété (2006) Le développement entre gouvernement et gouvernance: réflexion critique sur le rôle des institutions dans le développement. Pp. 97-113 in A. Ferguène ed., Gouvernance locale et développement territorial: le cas des pays du Sud: actes du Colloque international de Constantine, 26 et 27 avril 2003 (Paris: L'Harmattan)

Anholt, S. (2002) Nation branding: a continuing theme. Journal of Brand Management 10 (1) pp. 59-60

Anholt, S. (2004) Branding places and nations. Pp. 213-226 in R. Clifton, J. Simmons and S. Ahmad eds., Brands and branding (New York: Blomberg Press)

Anholt, S. (2005) Brand new justice (Oxford: Butterworth-Heinemann)

Anholt, S. (2006) Competitive identity: The new brand management for nations, cities and regions (Basingstoke: Palgrave Macmillan)

Anholt, S. (2006) Public diplomacy and place branding: Where's the link? Place Branding and Public Diplomacy 2 (4) pp. 271-275

Anholt, S. (2008) Place branding: Is it marketing, or isn't it? Place Branding and Public Diplomacy 4 (1) pp. 1-6

Anholt, S. (2010) Definitions of place branding - working towards a resolution. Place Branding and Public Diplomacy 6 (1) pp. 1-10

Ashworth, G. (2009) The instruments of place branding: How is it done? European Spatial research and policy 16 (1) pp. 9-22

Ashworth, G.J. and H. Voogd (1990) Selling the city: marketing approaches in public sector urban planning (London: Belhaven Press)

Aurier, P., F. Fort and L. Sirieix (2005) Exploring terroir product meanings for the consumer. Anthropology of food 4 , https://aof.revues.org/187?lang=fr

Ballaoui, A. (2009) L'organisation régionale au Maroc : vers une plus grande artificialisation de l'espace géographique. Pp. 79-92 in S. Boujrouf, B. Antheaume, F. Giraut and P. A. Landel eds., Les territoires à l'épreuve des normes: référents et innovations. Contributions croisées sud-africaines, françaises et marocaines (Marrakech Université Cadi Ayyad: Montagnes Méditerranéennes)

Balme, R. and B. Jouve (1996) Building the regional state: Europe and territorial organisation in France. Pp. 219-255 in L. Hooghe eds., Cohesion Policy and European Integration: Building Multi-Level Governance (New York: Oxford University Press) 
Baudelle, G., C. Guy and B. Mérenne-Schoumaker (2011) Le développement territorial en Europe. Concepts, enjeux et débats (Rennes: PUR)

Beach, D. and R.B. Pedersen (2013) Process-tracing Methods: Foundations and Guidelines (Ann Arbor: University of Michigan Press)

Beckman, B. and S. Zenker (2012) Place branding: A multiple stakeholder perspective. 41st European Marketing Academy Conference, Lisbon, Portugal, 22-25 May 2012

Belahsen, R. and M. Rguibi (2006) Population health and Mediterranean diet in southern Mediterranean countries. Public health nutrition 9 (8A) pp. 1130-1135

Bell, F. and A. Pike (2013) Place branding: origins, definitions and critique. Draft paper for the East China Normal University, Shanghai, http://ccmc.ecnu.edu.cn/upload/Article/201310/place\%20branding.doc.

Bellini, N., A. Loffredo and C. Pasquinelli (2010) Managing Otherness. The political economy of place images in the case of Tuscany. Pp. 89-115 in G. Ashworth and M. Kavaratzis eds., Towards effective place brand management: Branding European cities and regions, (Cheltenham: Edward Elgar Publishing)

Bérard, L. and P. Marchenay (2004) Les produits de terroir. Entre cultures et règlements (Paris: CNRS éditions)

Berg, B.L. (2009) An Introduction to Content Analysis. Pp. 1-15 in B. L. Berg ed., Qualitative research methods for the social sciences (Boston: Allyn \& Bacon)

Berg, P.O. and G. Sevón (2014) Food-branding places - A sensory perspective. Place Branding and Public Diplomacy 10 (4) pp. 289-304

Berry, L. (2000) Cultivating service brand equity. Journal of the Academy of Marketing Science 28 (1) pp. 128-137

Bitsch, V. (2005) Qualitative research: A grounded theory example and evaluation criteria. Journal of Agribusiness 23 (1) pp. 75-91

Boujrouf, S. and E. Hassani (2008) Toponymie et recomposition territoriale au Maroc: Figures, sens et logiques. L'Espace Politique, Revue en ligne de géographie politique et de géopolitique 5, https://espacepolitique.revues.org/228

Bowen, S. (2010) Embedding local places in global spaces: geographical indications as a territorial development strategy. Rural Sociology 75 (2) pp. 209-243

Boyne, S., D. Hall and F. Williams (2003) Policy, support and promotion for food-related tourism initiatives: A marketing approach to regional development. Journal of Travel \& Tourism Marketing 14 (3-4) pp. 131-154

Bramley, C. (2011) A review of the socio-economic impact of geographical indications: considerations for the developing world. WIPO Worldwide Symposium on Geographical Indications, Lima, Peru, 2224 June 2011

Braun, E. and S. Zenker (2010) Towards an integrated approach for place brand management. 50th European Regional Science Association Congress, Jönköping, Sweden, 19-22 August 2010

Brenner, N. (2003) Metropolitan institutional reform and the rescaling of state space in contemporary Western Europe. European Urban and Regional Studies 10 (4) pp. 297-324

Bristow, G. (2009) Limits to regional competitiveness (London: Smith Institute)

Bristow, G. (2010) Critical reflections on regional competitiveness: Theory, policy, practice (London: Routledge)

Bristow, G. (2010) Resilient regions: re-'place'ing regional competitiveness. Cambridge Journal of Regions, Economy and Society 3 (1) pp. 1-15

Broniarczyk, S.M. and J.W. Alba (1994) The importance of the brand in brand extension. Journal of Marketing Research 31 (2) pp. 214-228

Buck, N., I. Gordon, A. Harding and I. Turok (2005) Changing cities; Rethinking competitiveness, cohesion and governance (Basingstoke: Palgrave Macmillan) 
Burgess, J.A. (1982) Selling places: environmental images for the executive. Regional Studies 16 (1) pp. 117

Cai, L.A. (2002) Cooperative branding for rural destinations. Annals of tourism research 29 (3) pp. $720-$ 742

Calas, B., O. Marcel and C. Delfosse (2011) Patrimonialisations en Afrique. Lieux d'exception, normes et marginalités. Géographie et cultures 79, http://gc.revues.org/358

Caldwell, N. and J.R. Freire (2004) The differences between branding a country, a region and a city: Applying the Brand Box Model. The Journal of Brand Management 12 (1) pp. 50-61

Camagni, R. (2002) On the concept of territorial competitiveness: sound or misleading? Urban studies 39 (13) pp. 2395-2411

Camagni, R. and R. Capello (2013) Regional competitiveness and territorial capital: a conceptual approach and empirical evidence from the European Union. Regional Studies 47 (9) pp. 13831402

Campagne, P. and B. Pecqueur (2014) Le développement territorial: une réponse émergente à la mondialisation (Paris: ECLM)

Carbonara, N., Giannoccaro, I. and McKelvey, B. (2010) Making geographical clusters more successful: Complexity-based policies. Emergence: Complexity \& Organization 12(3) pp. 21-45.

Casabianca, F., B. Sylvander, Y. Noel, C. Béranger, J. Coulon and F. Roncin (2005) Terroir et Typicité: deux concepts-clés des Appellations d'Origine Contrôlée. Essai de définitions scientifiques et opérationnelles. International symposium "Territoires et enjeux du développement régional", Lyon, France, 9-11 March 2005

Chabin, Y., G. Naro and D. Travaillé (2003) Les tableaux de bord stratégiques entre conception et action: propos d'étapes d'une recherche intervention. 24ème congrès de l'Association Francophone de Comptabilité, Louvain-La-Neuve, Belgique, May 2003

Chabrol, D., M. Mariani and D. Sautier (2015) Establishing Geographical Indications without State Involvement? Learning from Case Studies in Central and West Africa. World Development (in press)

Changeur, S. (2002) Le capital-marque: concept et modèles. Cahier de Recherche, CEROG, IAE d'Aix-enProvence 648

Charters, S., R. Mitchell and D. Menival (2011) The territorial brand in wine. Sixth International Conference of the Academy of Wine Business Research, Bordeaux, France, June 2011

Chicoye, C. (1992) Regional impact of the Single European Market in France. Regional Studies 26 pp. 407-411

Clarkson, M.E. (1995) A stakeholder framework for analyzing and evaluating corporate social performance. Academy of management review 20 (1) pp. 92-117

Cohen, E. and N. Avieli (2004) Food in tourism: attraction and impediment. Annals of tourism research 31 (4) pp. 755-778

Colletis, G., C. Courlet, B. Pecqueur and F. Winterhalter (1990) Les Systèmes industriels localisés (Grenoble: IREPD)

Côté, S. (2003) Développement local: sur fond de proximité relationnelle, l'apport indispensable de l'extra-local. Interventions économiques 30, http://interventionseconomiques.revues.org/1002

Crowley, E. (2004) Selling regional identity: The case of Fuchsia Brands Ltd. Pp. 131-142 in M. Peillon and M.P. Corcoran eds., Place and Non-Place. The reconfiguration of Ireland (Dublin: IPA)

Czellar, S. (2003) Consumer attitude toward brand extensions: an integrative model and research propositions. International Journal of Research in Marketing 20 (1) pp. 97-115

Debarbieux, B. (1999) Le territoire: Histoires en deux langues. A bilingual history of territory. Pp. 38-39 in C. Chivallon, P. Ragouet and M. Samers eds., Discours scientifique et contextes culturels. Géographies françaises à l'épreuve postmoderne (Bordeaux: Maison des Sciences de l'homme d'Aquitaine) 
De Chernatony, L. and F. Harris (2000) Developing corporate brands through considering internal and external stakeholders. Corporate Reputation Review 3 (3) pp. 268-274

De Chernatony, L. and S. Segal-Horn (2003) The criteria for successful services brands. European Journal of Marketing 37 (7/8) pp. 1095-1118

De Roest, K. and A. Menghi (2000) Reconsidering 'traditional' food: the case of Parmigiano Reggiano cheese. Sociologia ruralis 40 (4) pp. 439-451

Dessein, J. (2015) Territorialisation in Practice: The Case of Saffron Cultivation in Morocco. Pp. 108-124 in J. Dessein, E. Battaglini and L. G. Horlings eds., Culture and Sustainability in Regional Development. Theories and practices of territorialisation. Routledge series on Cultural Sustainability and Regional Development. (London: Routledge)

Dinnie, K. (2004) Country-of-origin 1965-2004: a literature review. Journal of Customer Behaviour 3 (2) pp. $165-213$

Dinnie, K. (2004) Place branding: overview of an emerging literature. Place Branding and Public Diplomacy 1 (1) pp. 106-110

Dinnie, K. (2008) Nation branding: Concepts, issues, practice (London: Routledge)

Donner, M., F. Fort and S. Vellema (2014) How to capture place brand equity? The case of Sud de France. Place Branding and Public Diplomacy 10 (2) pp. 145-157

Doyle, P. (1989) Building successful brands: the strategic options. Journal of marketing management 5 (1) pp. 77-95

Eisenhardt, K.M. (1989) Building theories from case study research. Academy of management review 14 (4) pp. $532-550$

El Ansari, R. (2009) Dynamique régionale et développement inégal au Maroc. Inégalités et développement dans les pays méditerranéens, Université de Gala-Tasaray, Istanbul, Turquie, 2123 May 2009

El Ansari, R. (2013) Patrimoine et développement régional au Maroc. Cinquantième colloque de I'Association des sciences régionales de langue française (ASRDLF), Mons, 8-11 July 2013

EC (2010): Cohesion Policy Support for Local Development: Best practice and future policy options. Final Report.

EU (1999) Territorial competitiveness. Creating a territorial development strategy in light of the LEADER experience. LEADER European Observatory dossier no 6 (part 1)

EU (2011) Territorial Agenda of the European Union 2020: Towards an Inclusive, Smart and Sustainable Europe of Diverse Regions. Agreed at the Informal Ministerial Meeting of Ministers responsible for Spatial Planning and Territorial Development on 19th May 2011 (Gödöllö, Hungary)

Faludi, A. (2004) Territorial cohesion: old (French) wine in new bottles? Urban studies 41 (7) pp. 13491365

Fan, Y. (2006) Branding the nation: What is being branded? Journal of vacation marketing 12 (1) pp. 5-14

Fan, Y. (2010) Branding the nation: Towards a better understanding. Place Branding and Public Diplomacy 6 (2) pp. 97-103

FAO (2010) Sustainable diets and biodiversity. Directions and solutions for policy, research and action. Proceedings of the International Scientific Symposium FAO Headquarters, Rome, Italy, 3-5 November 2010

Farquhar, P.H. (1989) Managing Brand Equity. Marketing Research 1 (3) pp. 24-33

Fauvel, C. and M. Vanier (2006) Le Maroc. Le modèle français à l'épreuve du royaume et de la mondialisation. Pp. 97-108 in Ministère des Affaires Étrangères ed., Étude comparée des politiques d'aménagement du territoire et de développement régional dans les pays du Sud

Ferrell, O.C., T.L. Gonzalez-Padron, G.T.M. Hult and I. Maignan (2010) From Market Orientation to Stakeholder Orientation. Journal of Public Policy \& Marketing 29 (1) pp. 93-96 
Florek, M. (2015) Rethinking Brand Equity - Possibilities and Challenges of Application to Places. Pp. 225239 in M. Kavaratzis, G. Warnaby and G. Ashworth eds., Rethinking Place Branding (Heidelberg: Springer)

Florek, M. and M. Kavaratzis (2014) From brand equity to place brand equity and from there to the place brand. Place Branding and Public Diplomacy 10 (2) pp. 103-107

Fontanille, J. (2014) Territoire. Du lieu à la forme de vie. Actes Sémiotiques 117: http://epublications.unilim.fr/revues/as/5239

Fort, F. (2006) Alternatives marketing pour les produits de terroir. Revue française de gestion (3) pp. 145159

Foutrel, S. (2012) Les logiques décisionnelles du marquage territorial: une analyse par la cartographie cognitive appliquée au cas de" Produit en Bretagne". Doctoral Dissertation, University of Rennes

Fournier, S. (2015) Évaluer ex-ante l'impact d'une indication géographique? De la difficulté d'appréhender des processus d'action collective et d'innovation au sein de systèmes complexes. Économies et sociétés, série "Systèmes agroalimentaires" 37 (8) pp. 1167-1184.

Francois, H., M. Hirczak and N. Senil (2006) Territoire et patrimoine: la co-construction d'une dynamique et de ses ressources. Revue d'Économie Régionale \& Urbaine 5 pp. 683-700

Freeman, R.E. (1984) Strategic management: A stakeholder approach (Boston: Pitman)

Freire, J. (2014) Place branding in Africa. Place Branding and Public Diplomacy 10 (1) pp. 32-34

García, M.D.D., L. Horlings, P. Swagemakers and X.S. Fernández (2013) Place branding and endogenous rural development. Departure points for developing an inner brand of the River Minho estuary. Place Branding and Public Diplomacy 9 (2) pp. 124-140

Gardner, B.B. and S.J. Levy (1955) The product and the brand. Harvard Business Review 33 (2) pp. 33-39

Gerring, J. (2004) What is a case study and what is it good for? American political science review 98 (02) pp. 341-354

Gertner, D. (2007) Place branding: dilemma or reconciliation between political ideology and economic pragmatism? Place Branding and Public Diplomacy 3 (1) pp. 3-7

Gertner, D. (2011) Unfolding and configuring two decades of research and publications on place marketing and place branding. Place Branding and Public Diplomacy 7 (2) pp. 91-106

Gilly, J.P. and A. Torre (2000) Proximity relations: elements for an analytical framework. Pp. 1-16 in M. B. Green and R. B. M. Naughton eds., Industrial networks and proximity (Aldershot: Ashgate Publishing)

Gold, J.R. and S.V. Ward (1994) Place promotion: the use of publicity and marketing to sell towns and regions (Hoboken, New Jersey: John Wiley \& Sons Ltd)

Goodman, D. (2004) Rural Europe redux? Reflections on alternative agro-food networks and paradigm change. Sociologia ruralis 44 (1) pp. 3-16

Gracia, A., T. De Magistris and R.M. Nayga (2012) Importance of Social Influence in Consumers' Willingness to Pay for Local Food: Are There Gender Differences? Agribusiness 28 (3) pp. 361-371

Granovetter, M. (1985) Economic action and social structure: the problem of embeddedness. American journal of sociology 91 (3) pp. 481-510.

Gravier, J. (1947) Paris et le désert français (Paris: Flammarion)

Grönroos, C. (2001) Service management and marketing (New York: Wiley)

Gummesson, E. (2002) Relationship marketing in the new economy. Journal of Relationship Marketing 1 (1) pp. 37-57

Hadjou, L. (2009) Les deux piliers de la construction territoriale : coordination des acteurs et ressources territoriales. Développement durable et territoires: http://developpementdurable.revues.org/8208

Halinen, A. and J.Å. Törnroos (1998) The role of embeddedness in the evolution of business networks. Scandinavian Journal of Management 14 (3) pp. 187-205 
Hall, C.M., B. Cambourne, L. Sharples, N. Macionis and R. Mitchell (2003) Food Tourism Around the World development, management and markets (Oxford: Butterworth-Heinemann)

Hanf, J.H. and R. Kühl (2005) Branding and its consequences for German agribusiness. Agribusiness 21 (2) pp. 177-189

Hankinson, G. (2004) Academic Papers Relational network brands: Towards a conceptual model of place brands. Journal of Vacation Marketing 10 (2) pp. 109-121

Hankinson, G. (2010) Place branding research: A cross-disciplinary agenda and the views of practitioners. Place Branding and Public Diplomacy 6 (4) pp. 300-315

Hankinson, G. and P. Cowking (1993) Branding in action (Maidenhead: McGraw-Hill)

Hanna, S. and J. Rowley (2008) An analysis of terminology use in place branding. Place Branding and Public Diplomacy 4 (1) pp. 61-75

Harvey, D. (1989) From managerialism to entrepreneurialism: the transformation in urban governance in late capitalism. Geografiska Annaler. Series B. Human Geography 71B (1) pp. 3-17

Hatch, M.J. and M. Schultz (2010) Toward a theory of brand co-creation with implications for brand governance. Journal of Brand Management 17 (8) pp. 590-604

Helmsing, A. and S. Vellema (2012) Value chains, social inclusion and economic development: Contrasting theories and realities (London: Routeledge)

Hess, M. (2004) Spatial relationships? Towards a reconceptualization of embeddedness. Progress in Human Geography 28 (2) pp. 165-186

Hjalager, A.-M. and G. Richards (2003) Tourism and gastronomy (London: Routledge)

Horlings, L. and T. Marsden (2010) The new rural paradigm and redefining the rural web. Pp. 213-244 in P. Milone and F. Ventura eds., Networking the Rural: The Future of Green Regions in Europe (Assen: Van Gorcum)

Horlings, L.G. (2012) Place branding by building coalitions; lessons from rural-urban regions in the Netherlands. Place Branding and Public Diplomacy 8 (4) pp. 295-309

Horlings, L.G. and T.K. Marsden (2014) Exploring the 'New Rural Paradigm'in Europe: Eco-economic strategies as a counterforce to the global competitiveness agenda. European Urban and Regional Studies 21 (1) pp. 4-20

Ilbert H. (2005). Produits du terroir méditerranéen: conditions d'émergence, d'efficacité et mode de gouvernance. Rapport final du programme Femise (Montpellier: CIHEAM-IAMM)

Ilbery, B. and D. Maye (2007) Marketing sustainable food production in Europe: case study evidence from two Dutch labelling schemes. Tijdschrift voor economische en sociale geografie 98 (4) pp. 507-518

Iversen, N.M. and L.E. Hem (2008) Provenance associations as core values of place umbrella brands: A framework of characteristics. European Journal of Marketing 42 (5/6) pp. 603-626

Jacobsen, B.P. (2009) Investor-based place brand equity: a theoretical framework. Journal of Place Management and Development 2 (1) pp. 70-84

Jessop, B. (2001) Regulationist and autopoieticist reflections on Polanyi's account of market economies and the market society. New Political Economy 6 (2) pp. 213-232.

Jones, A. (2008) Beyond embeddedness: economic practices and the invisible dimensions of transnational business activity. Progress in Human Geography 32 (1) pp. 71-88

Jones, R. (2005) Finding sources of brand value: Developing a stakeholder model of brand equity. The Journal of Brand Management 13 (1) pp. 10-32

Kalandides, A., M. Kavaratzis, A. Lucarelli and P. Olof Berg (2011) City branding: a state-of-the-art review of the research domain. Journal of Place Management and Development 4 (1) pp. 9-27

Kapferer, J.-N. (1991) Les marques, capital de l'entreprise (Paris: Editions d'Organisation)

Kapferer, J.N. (2008) The New Strategic Brand Management: Creating and Sustaining Brand Equity Long Term (London: Kogan Page) 
Kaplan, R.S. and D.P. Norton (1996) The Balanced Scorecard: Translating Strategy into Action (Boston: Harvard Business School Press)

Karzazi, M. (2013) La coopération décentralisée franco-marocaine: entre coopération au développement et diplomatie économique d'influence. Thèse de doctorat, Université de Cergy Pontoise (France) and Université Abdelmalek Essaadi (Tétouan, Maroc)

Kasabov, E. and U. Sundaram (2013) A stakeholder approach to branding clusters: Pointers to a research agenda. Regional Studies 47 (4) pp. 530-543

Kauffman, S. (1995) At Home in the Universe, The Search for the Laws of Self-Organization and Complexity (Oxford: Oxford University Press)

Kavaratzis, M. (2005) Place Branding: A Review of Trends and Conceptual Models. Marketing Review 5 (4) pp. 329-342

Kavaratzis, M. (2012) From "necessary evil" to necessity: stakeholders' involvement in place branding. Journal of Place Management and Development 5 (1) pp. 7-19

Kavaratzis, M. and G.J. Ashworth (2005) City branding: an effective assertion of identity or a transitory marketing trick? Tijdschrift voor economische en sociale geografie 96 (5) pp. 506-514

Kavaratzis, M., G. Warnaby and G. Ashworth (2015) Rethinking Place Branding (Heidelberg: Springer)

Kearns, G. and C. Philo (1993) Culture, history, capital: A critical introduction to the selling of places. Pp. 1-32 in G. Kearns and C. Philo eds., Selling places: the city as cultural capital, past and present (London: Pergamon)

Keating, M. (1998) The new regionalism in Western Europe. Territorial restructuring and political change (Aldershot: Edward Elgar)

Keller, K.L. (1993) Conceptualizing, measuring, and managing customer-based brand equity. The Journal of Marketing 59 (1) pp. 1-22

Kitson, M., R. Martin and P. Tyler (2004) Regional competitiveness: an elusive yet key concept? Regional Studies 38 (9) pp. 991-999

Kneafsey, M. (2000) Tourism, place identities and social relations in the European rural periphery. European Urban and Regional Studies 7 (1) pp. 35-50

Koop, K., P.A. Landel and B. Pecqueur (2010) Pourquoi croire au modèle du développement territorial au Maghreb? Une approche critique. EchoGéo 13, http://echogeo.revues.org/12065

Kop, v.d. P., D. Sautier and A. Gerz (2006) Origin-based products: Lessons for pro-poor market development (Amsterdam: KIT)

Kotler, P. and D. Gertner (2002) Country as brand, product, and beyond: A place marketing and brand management perspective. The Journal of Brand Management 9 (4/5) pp. 249-261

Kotler, P., D. Haider and I. Rein (1993) There's no place like our place! The marketing of cities, regions, and nations. Futurist 27 (6) pp. 14-21

Kotler, P., I.D. Nebenzahl, V. Lebedenko, S. Rainisto, D. Gertner, R. Clifton, O.K. Peter van Ham and ncedil (2004) Where is place branding heading? Place Branding and Public Diplomacy 1 (1) pp. 12-35

Laczniak, G.R. and P.E. Murphy (2012) Stakeholder Theory and Marketing: Moving from a Firm-Centric to a Societal Perspective. Journal of Public Policy \& Marketing 31 (2) pp. 284-292

Landel, P.A. (2011) L'exportation du «développement territorial» vers le Maghreb: du transfert à la capitalisation des expériences. L'Information géographique 75 (4) pp. 39-57

Landel, P.A. and N. Senil (2009) Patrimoine et territoire, les nouvelles ressources du développement. Développement durable et territoires 12, http://developpementdurable.revues.org/7563

Lee, J., A. Árnason, A. Nightingale and M. Shucksmith (2005) Networking: social capital and identities in European rural development. Sociologia ruralis 45 (4) pp. 269-283

Leloup, F. (2005) La gouvernance territoriale comme nouveau mode de coordination territoriale? Géographie, économie, société 7 (4) pp. 321-332

Leuthesser, L. (1988) Defining, Measuring, and Managing Brand Equity: A Conference Summary (Cambridge, US: Marketing Science Institute) 
Logman, M. (2004) The LOGMAN model: a logical brand management model. Journal of Product and Brand Management 13 (2) pp. 94-104

Loureiro, M.L. and J.J. McCluskey (2000) Assessing consumer response to protected geographical identification labeling. Agribusiness 16 (3) pp. 309-320

Low, G.S. and R.A. Fullerton (1994) Brands, brand management, and the brand manager system: A critical-historical evaluation. Journal of Marketing Research 31 (2) pp. 173-190

MacDonagh, J., M. Woods and B. Nienaber (2015) Globalisation and Europes' Rural regions- Challenge and Opportunity. Pp. 1-17 in J. MacDonagh, B. Nienaber and M. Woods eds., Globalisation and Europe's rural regions. Perspectives on rural policy and planning (Farnham and Burlington: Ashgate)

Maillot, M., C. Issa, F. Vieux, D. Lairon and N. Darmon (2011) The shortest way to reach nutritional goals is to adopt Mediterranean food choices: evidence from computer-generated personalized diets. The American journal of clinical nutrition 94 (4) pp. 1127-1137

Malecki, E. (2004) Jockeying for position: what it means and why it matters to regional development policy when places compete. Regional Studies 38 (9) pp. 1101-1120

Marsden, T. (1998) New rural territories: regulating the differentiated rural spaces. Journal of rural studies 14 (1) pp. 107-117

Marsden, T. (2003) The condition of rural sustainability (Assen: Van Gorcum)

Marsden, T. (2006) The road towards sustainable rural development: issues of theory, policy and practice in a European context. Pp. 201-212 in P. Cloke, T. Marsden and P. Mooney eds., Handbook of rural studies (London: Sage)

Marsden, T., J. Banks and G. Bristow (2000) Food supply chain approaches: exploring their role in rural development. Sociologia ruralis 40 (4) pp. 424-438

Marsden, T. and R. Sonnino (2005) Rural development and agri-food governance in Europe. Pp. 50-68 in V. Higgins and G. Lawrence eds., Agricultural governance: Globalisation and the new politics of regulation (London: Routeledge)

Marsden, T. and R. Sonnino (2008) Rural development and the regional state: Denying multifunctional agriculture in the UK. Journal of rural studies 24 (4) pp. 422-431

McAdam, R., S.-A. Hazlett and C. Casey (2005) Performance management in the UK public sector: addressing multiple stakeholder complexity. International Journal of Public Sector Management 18 (3) pp. 256-273

Merieau, D. (2011) L'incubateur Produit en Bretagne: essai de compréhension et de modélisation. Doctoral dissertation, University Lyon 3

Messely, L., J. Dessein and L. Lauwers (2009) Branding regional identity as a driver for rural development. 113th European Association of Agricultural Economists-EAAE The role of knowledge, innovation and human capital in multifunctional agriculture and territorial rural development, Belgrade, Republic of Serbia, 9-11 December 2009

Meyronin, B. (2009) Le marketing territorial: enjeux et pratiques (Paris: Vuibert)

Milone, P. and F. Ventura (2010) Networking the rural: the future of green regions in Europe (Assen: Van Gorcum)

Mitchell, R.K., B.R. Agle and D.J. Wood (1997) Toward a theory of stakeholder identification and salience: Defining the principle of who and what really counts. Academy of management review 22 (4) pp. 853-886

Moilanen, T. and S. Rainisto (2009) How to brand nations, cities and destinations: A planning book for place branding (Basingstoke: Palgrave Macmillan)

Moragues-Faus, A.M. and R. Sonnino (2012) Embedding Quality in the Agro-food System: The Dynamics and Implications of Place-Making Strategies in the Olive Oil Sector of Alto Palancia, Spain.

Sociologia ruralis 52 (2) pp. 215-234 
Morgan, K. (2009) Feeding the city: The challenge of urban food planning. International Planning Studies 14 (4) pp. 341-348

Morgan, N., A. Pritchard and R. Pride (2002) Destination branding: creating the unique destination proposition (Oxford: Butterworth-Heinemann)

Morgan, N.J., A. Pritchard and R. Piggott (2003) Destination branding and the role of the stakeholders: The case of New Zealand. Journal of Vacation Marketing 9 (3) pp. 285-299

Murdoch, J., P. Lowe, N. Ward and T. Marsden (2003) The differentiated countryside (London: Routledge)

O'Connor, D., H. Renting, M. Gorman and J. Kinsella (2006) The evolution of rural development in Europe and the role of EU policy. Pp. 1-21 in D. O'Connor, H. Renting, M. Gorman and J. Kinsella eds., Driving Rural Development: Policy and Practice in Seven EU Countries (Assen: Van Gorcum)

O'Reilly, S. (2001) Fuchsia Brands Ltd: A case study of networking among the Food Producer Members (Cork: University College Cork)

O'Shaughnessy, J. and N.J. O'Shaughnessy (2000) Treating the nation as a brand: some neglected issues. Journal of Macromarketing 20 (1) pp. 56-64

OECD (2006) The new rural paradigm: Policies and Governance (Paris: Organisation for Economic Cooperation and Development)

OECD (2009) Regions Matter: Economic Recovery, Innovation and Sustainable Growth (Paris: OECD)

OECD (2011) Regional Outlook: Building resilient regions for stronger economies (Paris: OECD)

Oostindie, H., R. van Broekhuizen, J.G. Brunori and D. van der Ploeg (2008) The Endogeneity of Rural Economies. Pp. 53-67 in J. D. Van der Ploeg and T. Marsden eds., Unfolding webs: The dynamics of regional rural development (Assen: Van Gorcum)

Orth, U.R. and Z. Firbasová (2003) The role of consumer ethnocentrism in food product evaluation. Agribusiness 19 (2) pp. 137-153

Osei, C. and A. Gbadamosi (2011) Re-branding Africa. Marketing Intelligence \& Planning 29 (3) pp. 284304

Padilla, M. (2009) Comportements et sécurité alimentaires en Méditerranée. État des lieux et prospective. Futuribles (348) pp. 47-66

Papadopoulos, N. (2004) Place branding: Evolution, meaning and implications. Place branding 1 (1) pp. 36-49

Papadopoulos, N. and L. Heslop (2002) Country equity and country branding: Problems and prospects. The Journal of Brand Management 9 (4-5) pp. 4-5

Papadopoulos, N. and L.A. Heslop (2014) Product-country images: Impact and role in international marketing (London: Routledge)

Pasquinelli, C. (2010) The limits of place branding for local development: The case of Tuscany and the Arnovalley brand. Local Economy 25 (7) pp. 558-572

Pasquinelli, C. (2012) Competition, Cooperation, Co-opetition. Widening the perspective on Place Branding. PhD thesis, Scuola Superiore Sant'Anna

Pasquinelli, C. (2013) Competition, cooperation and co-opetition: Unfolding the process of interterritorial branding. Urban Research \& Practice 6 (1) pp. 1-18

Patel, R. (2009) Food sovereignty. The Journal of Peasant Studies 36 (3) pp. 663-706

Pecqueur, B. (1989) Le développement local: mode ou modèle? (Paris: Syros Alternatives)

Pecqueur, B. (2000) Le développement local: pour une économie des territoires (Paris: Syros Alternatives)

Pecqueur, B. (2001) Qualité et développement territorial: I'hypothèse du panier de biens et de services territorialisés. Économie rurale 261 (1) pp. 37-49

Pecqueur, B. (2013) Territorial development: A new approach to development processes for the economies of the developing countries. Revista internacional interdisciplinar INTERthesis 10 (2) pp. 8-32

Pecqueur, B. and J.B. Zimmermann (2004) Economie de proximités (Paris: Hermès-Lavoisier) 
Pedersen, S.B. (2004) Place branding: Giving the region of Øresund a competitive edge. Journal of Urban Technology 11 (1) pp. 77-95

Perrot, N. et al. (2015) Some remarks on computational approaches towards sustainable complex agrifood systems. Trends in Food Science \& Technology (in press)

Pike, A., A.R. Pose and J. Tomaney (2006) Local and regional development (London: Routledge)

Pike, A., A. Rodríguez-Pose and J. Tomaney (2007) What kind of local and regional development and for whom? Regional Studies 41 (9) pp. 1253-1269

Pinchemel, P. (1985) Aspects géographiques de l'aménagement d'un territoire. Fondaments Rationnels de l'Aménagement d'un Territoire (Paris: Masson)

Podnar, K. and Z. Jancic (2006) Towards a categorization of stakeholder groups: An empirical verification of a three-level model. Journal of Marketing Communications 12 (4) pp. 297-308

Polanyi, K. and R.M. Maciver (1957) The great transformation (Boston: Beacon Press)

Porter, M. (2003) The economic performance of regions. Regional Studies 37 (6-7) pp. 545-546

Porter, M.E. (2000) Location, competition, and economic development: Local clusters in a global economy. Economic development quarterly 14 (1) pp. 15-34

Quan, S. and N. Wang (2004) Towards a structural model of the tourist experience: An illustration from food experiences in tourism. Tourism management 25 (3) pp. 297-305

Rainisto, S.K. (2003) Success factors of place marketing: a study of place marketing practices in Northern Europe and the United States. Phd Thesis, Helsinki University of Technology

Rallet, A. and A. Torre (2004) Proximité et localisation. Économie rurale 280 (1) pp. 25-41

Rastoin, J.-L. (2009) Créer un label méditerranéen pour les produits agroalimentaires d'origine: quelques justifications théoriques et empiriques. Pp. 19-27 in Y. Tekelioglu, H. Ilbert and S. Tozanli eds., Les produits de terroir, les indications géographiques et le développement local durable des pays méditerranéens, Options méditerranéennes, A (89) (Paris: Ciheam)

Rastoin, J.L. (2012) The Concept of Terroir as the Basis of Corporate Strategy in Agribusiness: The European Social, Economic and Institutional Model. Pp. 117-136 in L. Augustin-Jean, H. Ilbert and N. Saavedra-Rivano eds., Geographical Indications and International Agricultural Trade: The Challenge for Asia (Basingstoke: Palgrave Macmillan)

Ray, C. (1998) Culture economies: A perspective on local rural development in Europe. Working paper no 25, University of Newcastle upon Tyne: Centre for Rural Economy, Dept. of Agricultural Economics and Food Marketing, http://www.ncl.ac.uk/cre/publish/Books/CultureEconfinal.pdf

Ray, C. (2006) Neo-endogenous rural development in the EU. Pp. 278-291 in P. Cloke, T. K. Marsden and P. H. Mooney eds., Handbook of rural studies (London: Sage)

Renting, H., T.K. Marsden and J. Banks (2003) Understanding alternative food networks: exploring the role of short food supply chains in rural development. Environment and planning A 35 (3) pp. 393-412

Roep, D., W. Wellbrock and L.G. Horlings (2015) Raising self-efficacy and resilience: collaborative leadership in the Westerkwartier. Pp. 41-58 in B. N. M. Woods, J. McDonagh ed., Globalisation and Europe's rural regions (Surrey: Ashgate)

Roosen, J., J.L. Lusk and J.A. Fox (2003) Consumer demand for and attitudes toward alternative beef labeling strategies in France, Germany, and the UK. Agribusiness 19 pp. 77-90

Roques, G. (2010) Paradoxes en Languedoc-Roussillon: une région surfaite (Pau, France: Cairn)

Saito, H. and Y. Saito (2013) Motivations for Local Food Demand by Japanese Consumers: A Conjoint Analysis with Reference Point Effects. Agribusiness 29 (2) pp. 147-161

San Eugenio Vela, J. (2013) Place branding: a conceptual and theoretical framework. Boletin de la Asociacion de Geografos Espanoles 62 pp. 189-211

Savage, G.T., T.W. Nix, C.J. Whitehead and J.D. Blair (1991) Strategies for assessing and managing organisational stakeholders. The executive 5 (2) pp. 61-75 
Scarpa, R., G. Philippidis and F. Spalatro (2005) Product-country images and preference heterogeneity for Mediterranean food products: A discrete choice framework. Agribusiness 21 (3) pp. 329-349

Scott, A.J. and G. Garofoli (2011) Development on the ground: clusters, networks and regions in emerging economies (London: Routledge)

Scott, A.J. and M. Storper (2007) Regions, globalisation, development. Regional Studies 41 (S1) pp. S191S205

Shimp, T.A., S. Samiee and T.J. Madden (1993) Countries and their products: a cognitive structure perspective. Journal of the Academy of Marketing Science 21 (4) pp. 323-330

Shimp, T.A. and S. Sharma (1987) Consumer ethnocentrism: construction and validation of the CETSCALE. Journal of Marketing Research pp. 280-289

Simms, J. (2008) Lands of hype and glory. Director Magazine 61 (8), p. 48

Simon, C., P. Huigen and P. Groote (2010) Analysing regional identities in the Netherlands. Tijdschrift voor economische en sociale geografie 101 (4) pp. 409-421

Simon, C.J. and M.W. Sullivan (1993) The measurement and determinants of brand equity: a financial approach. Marketing science 12 (1) pp. 28-52

Skaggs, R., C. Falk, J. Almonte and M. Cárdenas (1996) Product-country images and international food marketing: Relationships and research needs. Agribusiness 12 (6) pp. 593-600

Skuras, D., E. Dimara and A. Petrou (2006) Rural tourism and visitors' expenditures for local food products. Regional Studies 40 (7) pp. 769-779

Smith, A.D. (1991) National identity (Nevada: University of Nevada Press)

Sonnino, R. (2007) Embeddedness in action: Saffron and the making of the local in southern Tuscany. Agriculture and Human Values 24 (1) pp. 61-74

Srinivasan, V. (1979) Network models for estimating brand-specific effects in multi-attribute marketing models. Management Science 25 (1) pp. 11-21

Stanton, J.V. (2000) The role of agribusiness in development: Replacing the diminished role of the government in raising rural incomes. Journal of Agribusiness 18 (2) pp. 173-188

Stervinou, S., Nantes, A. \& Lê, S. (2006) Une méthodologie pour analyser les groupements localisés d'entreprises: le cas de l'association "Produit en Bretagne". 8ème CIFEPME, L'internationalisation des PME et ses conséquences sur les stratégies entrepreneuriales, Haute école de gestion (HEG), Fribourg, Suisse, 25-27 octobre 2006

Stoker, G. (1998) Governance as theory: five propositions. International social science journal 50 (155) pp. $17-28$

Storper, M. (1997) The regional world: territorial development in a global economy (London: Guilford Press)

Stubbs, J. and G. Warnaby (2015) Rethinking Place Branding from a Practice Perspective: Working with Stakeholders. Pp. 101-118 in M. Kavaratzis, G. Warnaby and G. Ashworth eds., Rethinking Place Branding (Heidelberg: Springer)

Szondi, G. (2008) Public diplomacy and nation branding: Conceptual similarities and differences. Discussion Papers in Diplomacy no 112, The Netherlands Institute of International Relations 'Clingendael'

Szondi, G. (2010) From image management to relationship building: A public relations approach to nation branding. Place Branding and Public Diplomacy 6 (4) pp. 333-343

Therkelsen, A. and H. Halkier (2004) Umbrella place branding: A study of friendly exoticism and exotic friendliness in coordinated national tourism and investment promotion. Discussion paper no 26, SPIRIT (School for Postgraduate Interdisciplinary Research on Interculturalism and Transnationality).

Therkelsen, A. and H. Halkier (2008). Contemplating place branding umbrellas. The case of coordinated national tourism and business promotion in Denmark. Scandinavian Journal of Hospitality and Tourism 8(2)pp. 159-175. 
Ton, G. (2012) The mixing of methods: A three-step process for improving rigour in impact evaluations. Evaluation 18 (1) pp. 5-25

Ton, G., S. Vellema and M. de Ruyter de Wildt LEl (2011) Development impacts of value chain interventions: how to collect credible evidence and draw valid conclusions in impact evaluations? Journal on Chain and Network Science 11 (1) pp. 69-84

Trébucq, S. (2011) Le balanced scorecard en France. Revue Francaise de Gestion 211 (2) pp. 131-143

Tregear, A. (2011) Progressing knowledge in alternative and local food networks: critical reflections and a research agenda. Journal of rural studies 27 (4) pp. 419-430

Tregear, A., F. Arfini, G. Belletti and A. Marescotti (2007) Regional foods and rural development: the role of product qualification. Journal of rural studies 23 (1) pp. 12-22

Tregear, A., S. Kuznesof and A. Moxey (1998) Policy initiatives for regional foods: some insights from consumer research. Food Policy 23 (5) pp. 383-394

Uzzi, B. (1996) The sources and consequences of embeddedness for the economic performance of organisations: The network effect. American sociological review 61 (4) pp. 674-698

Van der Ploeg, J.D., A. Long and J. Banks (2002) Rural development: the state of the art. Pp. 8-17 in J. D. Van der Ploeg, A. Long and J. Banks eds., Living Countryside's: Rural Development Processes in Europe: The State of the Art (Doetinchem: Elsevier)

Van der Ploeg, J.D. and T. Marsden (2008) Unfolding webs: the dynamics of regional rural development (Assen: Van Gorcum)

Van Der Ploeg, J.D. and H. Renting (2000) Impact and potential: a comparative review of European rural development practices. Sociologia ruralis 40 (4) pp. 529-543

Van der Ploeg, J.D., H. Renting, G. Brunori, K. Knickel, J. Mannion, T. Marsden, K. De Roest, E. SevillaGuzmán and F. Ventura (2000) Rural development: from practices and policies towards theory. Sociologia ruralis 40 (4) pp. 391-408

Van der Ploeg, J.D., R. Van Broekhuizen, G. Brunori, R. Sonnino, K. Knickel, T. Tisenkopfs and H. Oostindie (2008) Towards a framework for understanding regional rural development. Pp. 1-28 in J. D. v. d. Ploeg and T. Marsden eds., Unfolding webs: The dynamics of regional rural development (Assen: Van Gorcum)

Van Ham, P. (2001) The rise of the brand state: the postmodern politics of image and reputation. Foreign affairs 80 (5) pp. 2-6

Van Ham, P. (2008) Place branding: the state of the art. The Annals of the American Academy of Political and Social Science 616 (1) pp. 126-149

Van Ittersum, K. (2002) The role of region of origin in consumer decision-making and choice. PhD thesis, Mansholt Graduate School, University of Wageningen

Vanclay, F. (2011) Endogenous rural development from a sociological perspective. Pp. 59-69 in R. J. Stimson, R. Stough and P. Nijkamp eds., Endogenous regional development: Perspectives, measurement and empirical investigation (Cheltenham and Northhampton: Edward Elgar Publishing)

Vandecandelaere, É. and S. Abis (2012) Alimentation, tourisme et collectivités territoriales. Pp. 447-465 in CIHEAM ed., MediTERRA 2012 (Paris: Presses de Sciences Po)

Vandecandelaere, E., F. Arfini, G. Belletti and A. Marescotti (2009) Linking people, places and products, a guide for promoting quality linked to geographical origin and sustainable geographical indications (Rome: FAO)

Venn, L., M. Kneafsey, L. Holloway, R. Cox, E. Dowler and H. Tuomainen (2006) Researching European 'alternative'food networks: some methodological considerations. Area 38 (3) pp. 248-258

Verlegh, P.W. and J.B.E. Steenkamp (1999) A review and meta-analysis of country-of-origin research. Journal of economic psychology 20 (5) pp. 521-546

Von Alvensleben, R. (2000) Zur Bedeutung von Emotionen bei der Bildung von Präferenzen für regionale Produkte. Agrarwirtschaft 49 pp. 399-402 
Wanjiru, E. (2006) Branding African countries: A prospect for the future. Place Branding and Public Diplomacy 2 (1) pp. 84-95

Ward, N. and D.L. Brown (2009) Placing the rural in regional development. Regional Studies 43 (10) pp. 1237-1244

Wellbrock, W., D. Roep and J. Wiskerke (2012) An integrated perspective on rural regional learning. European Countryside 4 (1) pp. 1-16

Wernerfelt, B. (1988) Umbrella branding as a signal of new product quality: an example of signalling by posting a bond. The Rand Journal of Economics 19 (3) pp. 458-466

Winter, M. (2003) Responding to the crisis: the policy impact of the foot-and-mouth epidemic. The Political Quarterly 74 (1) pp. 47-56

Wirthgen, A. (2005) Consumer, retailer, and producer assessments of product differentiation according to regional origin and process quality. Agribusiness 21 (2) pp. 191-211

Wiskerke, J. (2007) Robuuste regio's: dynamiek, samenhang en diversiteit in het metropolitane landschap. Inaugurale rede, 15-11-2007 (Wageningen: WUR)

Wiskerke, J.S.C. (2009) On places lost and places regained: Reflections on the alternative food geography and sustainable regional development. International Planning Studies 14 (4) pp. 369-387

Wittman, H. (2009) Reworking the metabolic rift: La Vía Campesina, agrarian citizenship, and food sovereignty. The Journal of Peasant Studies 36 (4) pp. 805-826

Wood, L. (2000) Brands and brand equity: definition and management. Management decision 38 (9) pp. 662-669

Woods, M. and J. Deeganm (2006) The fuchsia destination quality brand: Low on quality assurance, high on knowledge sharing. Journal of Quality Assurance in Hospitality \& Tourism, 7 (1-2) pp. 75-98

Woods, M. (2007) Engaging the global countryside: globalisation, hybridity and the reconstitution of rural place. Progress in Human Geography 31 (4) pp. 485-507

Woods, M. and D. Ramsey (2013) Regions engaging globalisation: A typology of regional responses in rural Europe. Journal of Rural and Community Development 8 (3) pp. 113-126

Yin, R. (1994) Case study research: Design and methods (Sage publishing: Thousand Oaks, CA)

Yin, R.K. (2003) Case study research design and methods (Sage Publications: Thousand Oaks, CA)

Yoo, B. and N. Donthu (2001) Developing and validating a multidimensional consumer-based brand equity scale. Journal of Business Research 52 (1) pp. 1-14

Zenker, S. and E. Braun (2015) Rethinking the Measurement of Place Brands. Pp. 211-223 in M. Kavaratzis, G. Warnaby and G. Ashworth eds., Rethinking Place Branding (Heidelberg: Springer)

Zenker, S. and B.P. Jacobsen (2015) Inter-Regional Place Branding (Heidelberg: Springer)

Zhang, J., B. Madsen and C. Jensen-Butler (2007) Regional economic impacts of tourism: the case of Denmark. Regional Studies 41 (6) pp. 839-854 


\section{Online references}

\section{Chapter 1}

Mahé V. (29-30/042013) : Le branding des territoires: Une marque territorial, quel intérêt et comment faire ? http://fr.slideshare.net/AgenceSouple/le-branding-des-territoires-une-marqueterritoriale-quel-intrt-et-comment-faire-25411314. Last accessed 7 January 2016.

BBDO consulting (16/07/2003): Analyse ausgewählter Regionalmarken. http://www.markeostfriesland.de/cms.nsf/84dd8423613e847ac1257401005b583b/85065d20caebe1bbc12575240 0450bca/\$FILE/Regionenanalyse\%2011.07.03_niedrige_Aufloesung.pdf. Last accessed 7 January 2016.

http://placebrandobserver.com/interview-professor-nicolas-papadopoulos-carleton-university-canada/ Last accessed 7 January 2016.

CIHEAM/FAO (2015) Mediterranean food consumption patterns: diet, environment, society, economiy and health. A White Paper Priority 5 of Feeding Knowledge Programme, Expo Milan, 2015: http://www.fao.org/3/a-i4358e.pdf. Last accessed 7 January 2016.

http://ec.europa.eu/regional_policy/en/policy/what/investment-policy/Last accessed 7 January 2016. http://ec.europa.eu/agriculture/quality/schemes/index_en.htm

WIPO: Geographical Indications. An introduction. http://www.wipo.int/edocs/pubdocs/en/geographical/952/wipo_pub_952.pdf. Last accessed 7 January 2016.

WIPO (2007): WIPO Asia Sub-Regional Workshop on the Use of Intellectual Property (IP) by SME Support Institutions for the Promotion of Competitiveness of SMEs in the Food Processing Sector. Topic 4: The Role of Trademarks, Collective Marks, Certification Marks and Geographical Indications in Marketing Food Products. http://www.wipo.int/meetings/fr/doc_details.jsp?doc_id=81475. Last accessed 7 January 2016.

FAO: Geographical Indications, local regulations and protection. http://www.fao.org/fileadmin/user_upload/foodquality/fichefiles/en/c2.3.pdf. Last accessed 7 January 2016.

United Nations statistical data: http://data.un.org/CountryProfile.aspx?crName=MOROCCO. Last accessed 7 January 2016.

\section{Chapter 2}

www.sud-de-france.com. Last accessed 8 June 2015.

www.sud-de-france-developpement.fr. Last accessed 8 June 2015.

www.qualite-suddefrance.com. Last accessed 20 May 2013.

www.lalettrem.fr (17 November 2009): Campagne des produits Sud de France en GD. Last accessed 18 January 2012.

www.lalettrem.fr (18 January 2011): La campagne d'été Sud de France a fait fort. Last accessed 25 November 2012.

www.lalettrem.fr (28 February 2012): Sud de France en Grande Distribution. Last accessed 25 November 2012.

www.laregion.fr: Délibération du Conseil Régional. Schéma régional de développement touristique. Politique régionale du tourisme. Repenser le tourisme en Languedoc-Roussillon. http://www.laregion.fr/uploads/Deliberations/ConseilRegional/2011/01/28/DELIBERATION/D0J OM.pdf. Last accessed 10 May 2013. 
http://draaf.languedoc-roussillon.agriculture.gouv.fr/Tourisme-rural:

Tourisme rural. Quelles perspectives pour le tourisme rural au Languedoc-Roussillon? Last accessed 10 April 2013.

www.observatoiredessubventions.com:

Comment Georges Frêche dépense l'argent de vos impôts (3 February 2010).

Georges Frêche roi de la dépense (4 February 2010). Last accessed 15 March 2013.

Agreste document (2011): Booster le " made in Languedoc-Roussillon » avec la marque Sud de France. http://www.regionsmagazine.com/site/articles/languedoc-roussillon/2010/06/2010-0629/Sud\%20de\%20france\%202010.pdf. Last accessed 22 November 2012.

Ballout, J.-M.: Discussion of the book written by Georges Roques (2010), "Paradoxes en LanguedocRoussillon: une région surfaite?" on 17 May 2011, $19 \mathrm{~h} 30$ at Café Riche http://www.cafe-geo.net/article.php3?id_article=2181. Last accessed 15 November 2012.

De Caix C., Domergue M. and Couderc J.-P. (2011): État des lieux et évolutions de la sphère agroalimentaire du Languedoc-Roussillon de 1997 à 2009.

www.agreste.agriculture.gouv.fr/IMG/pdf_R9111A16.pdf. Last accessed 20 November 2012.

Dominé A. (2012): Sud de France - Eine wahre Revolution. In : Pressemappe 2012 - Sud de France. http://www.festival-suddefrance.com/fileadmin/fichiers/Logo_All/EXE_DPSDF_All.pdf. Last accessed 15 December 2012.

Fritsch I. (13 June 2011): La marque Sud de France fête ses 5 ans. http://www.objectif-Ir.com/languedocroussillon/Actualites/La-marque-Sud-de-France-fete-ses-5-ans_1295.htm. Last accessed 12 February 2013.

Galbrun C. (January 2012): Sud de France, entre identité individuelle et identité collective pour les vins du Langudoc-Roussillon. http://www.pleinchamp.com/viticulture/actualites/sud-de-france-entreidentite-individuelle-et-identite-collective-pour-les-vins-du-languedoc-roussilon. Last accessed 10 March 2013.

Manceau Jean-Jacques (01/10/2010) : Bretagne contre Languedoc : le duel des labels régionaux. http://lexpansion.lexpress.fr/entreprise/bretagne-contre-languedoc-le-duel-des-labelsregionaux_239678.html?p=2. Last accessed 20 January 2013

McGinty C. (20 May 2008): Sud de France to highlight Languedoc Roussillon wines. http://www.thisfrenchlife.com/thisfrenchlife/2008/05/sud-de-france-t.html. Last accessed 13 March 2013.

Molénat, J. (27 October 2005): Le recul de Frêche l'intraitable. http://www.lexpress.fr/informations/le-recul-de-freche-l-intraitable_668491.html. Last accessed 14 February 2013.

Panayoty L. and Bouchindhomme J. (21 February 2012): Conférence de presse sur les chiffres de la marque Sud de France à l'international 2006-2011.

http://www.medium-message.com/presseSDFD/DP_confpresse_vinisud2012.pdf. Last accessed 25 January 2013.

Percq Y. (27 February 2012): La réussite des vins Sud de France à l'export se confirme. http://www.objectif-Ir.com/languedoc-roussillon/Actualites/La-reussite-des-vins-Sud-de-Francea-l-export-se-confirme_1573.html. Last accessed 20 January 2013.

Peyral-Bon D.: Sud de France. Languedoc-Roussillon's Finest. www.sommeliers-international.com/en/world/sud-de-france-_-languedoc-roussillon_sfinest.aspx. Last accessed 22 November 2012.

TNS Sofres (November 2007): Les perceptions des réalisations et projets de la Région LanguedocRoussillon. 7 - La marque Sud de France. http://www.tns-sofres.com/_assets/files/301107_languedocroussillon.pdf. Last accessed 20 January 2013. 


\section{Chapter 4}

http://www.produitenbretagne.bzh/ Last accessed 8 June 2015.

http://www.produitenbretagne.bzh/les-chiffres-cles. Last accessed 8 June 2015.

Press release of the Produit en Bretagne Association: http://www.lemoci.com/media/produit-enbretagne. Last accessed 2 February 2016.

www.insee.fr/fr/regions/bretagne. Last accessed 8 June 2015.

http://insee.fr/fr/themes/document.asp?reg_id=2andref_id=8606. Last accessed 8 June 2015.

Baldos R. (2013): 'Produit en Bretagne, précurseur du made in'. http://www.la-croix.com/Archives/201303-14/Produit-en-Bretagne-precurseur-du-made-in-_NP_-2013-03-14-921195. Last accessed 5 February 2016.

ODIS, Observatoire du dialogue et de l'intelligence sociale (2010). L'Etat social de la France. Lien social et performance de la Bretagne : Identité collective, Identité culturelle.

http://www.bretagne.fr/internet/upload/docs/application/pdf/2011-

06/focus_lien_social_et_performance_de_la_bretagne_2011-06-24_13-51-9_336.pdf Last accessed 8 June 2015.

www.westcorkaplaceapart.com (www.fuchsiabrands.com). Last accessed 8 June 2015.

www.wcdp.ie. Last accessed 8 June 2014.

Leader European Observatory (1999). WEST CORK (Ireland). Developing a regional branded identity to promote excellence. Last accessed 02 February 2013.

http://ec.europa.eu/ourcoast/download.cfm?fileID=871. Last accessed 8 June 2015.

Ryan, J., O'Reilly, S. and P. Enright (2004) Rural Enterprise Development \& Sustainability. Innovative Approaches to the needs of rural areas. Technical Report, Department of Food Business \& Development UCC.

https://www.ucc.ie/en/media/academic/foodbusinessanddevelopment/Report3.pdf. Last accessed 10 February 2015.

Dempsey I. and S. O'Reilly (2008) Perspectives on the West Cork Regional Brand.

http://www.westcorkaplaceapart.com/fileadmin/user_upload/PDF_Library/perspectives.pdf. Last accessed 8 June 2015.

www.sud-de-france.com. Last accessed 8 June 2015.

www.suddefrance-developpement.com. Last accessed 8 June 2015.

www.insee.fr/fr/regions/languedoc. Last accessed 8 June 2015.

http://www.observatoiredesgaspillages.com: Comment Georges Frêche dépense l'argent de vos impôts (3 February 2010). Last accessed 8 June 2015.

http://www.laregion.fr/epublication/206/35-l-accent-du-sud-n-39-juin-2015.htm.

Last accessed 2 February 2016.

Press release 2015: http://www.sud-de-france.com/wp-content/uploads/2015/06/DP-sud-defrance_DOSSIER.pdf. Last accessed 2 February 2016.

www.echt-schwarzwald.de. Last accessed 8 June 2015.

Koch F. (2008): „Echt Schwarzwald“: Regionale Rindfleischvermarktung im Schwarzwald; in: Landkreisnachrichten Baden-Württemberg, 47. Jahrgang. http://www.landkreistag-bw.de/aktuell/zeit/2008/mat/LKN3_08_196_198.pdf. Not accessible any more.

Kuhnert H. (01/05/2011): Regionalmarke verdoppelt ihren Umsatz. http://www.schwarzwaelder-bote.de/inhalt.freudenstadt-regionalmarke-verdoppelt-ihrenumsatz.ab0bc9e3-3dab-432f-9820-37a331b55b64.html. Last accessed 8 June 2015. 


\section{Chapter 5}

http://www.lemag.ma/Regionalisation-avancee-consecration-des-valeurs-de-la-democratieparticipative_a62489.html. Last accessed 7 January 2016.

http://www.agreste.agriculture.gouv.fr/IMG/pdf_AE2030_Politiques_d_amenagement_du_territoire.pdf Last accessed 7 January 2016.

http://www.maroc.ma/fr/content/tourisme. Last accessed 7 January 2016.

http://lavieeco.com/news/actualite-maroc/tourisme-le-maroc-determine-a-atteindre-les-objectifs-de-lavision-2020-27657.html. Last accessed 7 January 2016.

Haimoud, A. (2012) Décentralisation: Les 12 chantiers de la régionalisation. Aujourd'hui. Le Maroc. http://www.aujourdhui.ma/une/faste-train/decentralisation-les-12-chantiers-de-laregionalisation--96933. Last accessed 7 January 2016.

Markessenis, A. (2009) Nation branding for African countries.

http://nation-branding.info/2009/09/23/nation-branding-african-countries. Last accessed 7 January 2016. 


\section{Summary}

Place branding strategies linking marketing to places have received increasing attention in practice and theory in the past two decades. It is generally assumed that place branding contributes to the economic, social, political and cultural development of cities, regions and countries. But there exists neither a commonly accepted definition nor a sound theoretical framework for place branding research. Studies have until now mainly focused on nations and cities, while the regional scale has rather been neglected, even more in the context of Mediterranean countries. In addition, little is yet known about the conditions, processes, and outcomes of place branding.

The objective of this thesis is to contribute to the clarification of the place branding concept and to a broader understanding of this rich and complex phenomenon. The focus is on the underlying conditions, processes and dynamics of place branding in regions that contributes to territorial development. Place branding is related to local food products and tourism for sustainable territorial development in Mediterranean rural regions (in France and Morocco).

The introduction chapter outlines the societal and theoretical context of place branding regarding this thesis. Place brands have emerged as attempts to respond to intertwined and multifaceted economic, political and socio-cultural challenges: to the externalities of globalisation, to local development challenges due to regionalisation and decentralisation processes, and to socioeconomic tensions in the Mediterranean basin and its food domain. Accordingly, three established literature streams are mobilized: the marketing and branding of places, regional studies and sociology. It is supposed that insights from the three disciplines are needed to understand the conditions, processes and development outcomes of regional branding. This leads to three units of analysis: the first deals with place branding in a narrow sense, understanding it as marketing strategy for the development of places and their local assets based on a distinctive territorial identity; the second considers territorial development policies and public-private interactions; and the third analyses place-based, collective and embedded processes among various actors in rural areas. 
Chapter 2 comprises a case study of the Sud de France brand in the region LanguedocRoussillon, which is mainly used for the valorisation and promotion of local wines, food and tourism, but also serving institutional aims. It is a study of local dynamics and the process of regional branding, leading to beneficial outcomes stemming from a public development intervention. It demonstrates various economic and non-economic benefits created by a place brand and unfolds some of its working mechanisms, such as horizontal and vertical relations among different territorial actors, a multiple stakeholder involvement, or the linkage of a place brand with its political, social and economic context.

Chapter 3 is a continuation of Chapter 2, as it further investigates the kind of value that can be created by a place brand for different stakeholders, using the Sud de France case. Based on stakeholder and brand equity theory, it develops a measurement model and monitoring tool for the value of place brands. Results show that various place brand value dimensions coexist, according to the expectations of four identified key stakeholder groups. These value dimensions include economic, socio-cultural and environmental indicators.

Chapter 4 offers a comparison of four regional branding initiatives in Europe, with the aim to gain insights into the general conditions, as well as context-dependent factors for successfully developing and maintaining place brands. It combines a marketing perspective with the sociology of food and endogenous rural development, and analyses strategic and operational brand management aspects, as well as contextual factors. Findings indicate the importance of various embeddedness dimensions for regional branding, such as public policies, cooperation and governance forms, territorial identity and the anchorage of local actors in their places.

Chapter 5 is an explorative case study of place branding in the province of Chefchaouen, Morocco, in order to find out whether and how it would be possible to implement there a place brand as a coherent and collective territorial development project. Preconditions and various initiatives towards place branding are analysed at three action levels (macro, meso, micro). Specific attention is given to local cooperation and network activities, to leadership and political unity, being strongly related to the question of territorial governance. The main insight gained from the Chefchaouen case is that a collective place brand could be a useful tool for cross-sector cooperation, territorial governance and development, but that currently Moroccan regions still lack sufficient autonomy to fully develop their own territorial projects. 
The final chapter builds upon the research findings to highlight conceptual differences between diverse brands related to places. The main conclusion of this thesis is that place brands in regions - in order to be able to support agribusiness and local development - must be considered as more than mere marketing instruments, but as dynamic, collective and embedded territorial development processes. These insights lead to conceptual and theoretical, methodological, as well as policy and managerial implications, for place branding research and practice. A main suggestion for further research is to use complex systems theory to cover the complexity of place brands. 


\section{Résumé}

Depuis deux décennies les stratégies de 'place branding' qui lient le marketing aux territoires ont attiré de plus en plus de l'attention, dans la pratique et dans la théorie. En général, on suppose que le marketing territorial contribue au développement économique, social, politique et culturel des villes, des régions et des pays. Mais il n'existe ni une définition généralement acceptée ni un cadre théorique solide pour la recherche du marketing territorial. Jusqu'à maintenant, les travaux se sont surtout intéressés au marketing des pays et des villes, pendant que l'échelle régionale a été plutôt négligée, surtout dans un contexte des pays Méditerranéens. En outre, peu est encore connu concernant les déterminants, le processus et les effets du marketing territorial.

L'objectif de cette thèse est de contribuer à l'éclaircissement du concept du marketing territorial et à la compréhension de ce phénomène tellement riche et complexe. L'accent est mis sur les conditions sous-jacents, les processus et les dynamiques des marques territoriales régionales qui contribuent au développement territorial. Le marketing territorial est donc lié ici aux produits de terroir et au tourisme pour un développement territorial et durable dans des régions Méditerranéennes rurales (en France et au Maroc).

L'introduction à la thèse (chapitre 1) présente le contexte socio-politique et théorique du marketing territorial concernant cette thèse. Le marketing territorial a émergé comme la tentative de répondre aux défis économiques, politiques et socio-culturels étant interdépendants et multidimensionnels : aux externalités de la globalisation, au défi d'un développement local qui est la suite des processus de régionalisation et de décentralisation, et aux tensions socioéconomiques dans le bassin Méditerranéen et son domaine agroalimentaire. Par conséquent, trois courants littéraires établis sont mobilisés : le marketing et le 'branding' territorial, la science régionale et la sociologie. On présume que les connaissances de ces trois disciplines sont nécessaires pour comprendre les déterminants, le processus et les effets de développement d'un marketing territorial. Cela conduit par conséquent à trois unités d'analyse : la première porte sur le marketing territorial au sens strict, et le considère comme une stratégie de développement des territoires et de leurs ressources locales, une stratégie qui a comme base une identité territoriale distincte; la deuxième unité traite les politiques de développement territorial et les interactions publiques-privées; et la troisième analyse les processus locaux, collectifs et socialement encastrés entre de divers acteurs en zones rurales. 
Le chapitre 2 comprend une étude de cas de la marque Sud de France dans la région LanguedocRoussillon ; cette marque est principalement utilisée pour mettre en valeur et promouvoir les vins et les produits agroalimentaires locaux ainsi que le tourisme, mais elle sert également à des objectifs institutionnels. C'est une étude des dynamiques locales et du processus de marketing territorial, qui ont conduit à des effets positifs de développement suite à une intervention publique. Le cas montre les bénéfices économiques et non-économiques divers créés par cette marque territoriale et il révèle certains des mécanismes d'une marque collective territoriale, tels que les relations horizontales et verticales parmi de différents acteurs locaux, la mobilisation de multiples parties prenantes ou l'articulation de la marque territoriale avec son contexte politique, social et économique.

Le chapitre 3 est une sorte de suite du chapitre 2 car utilisant le cas de Sud de France il approfondit encore la question de la valeur qui peut être créé par une marque territoriale pour de différentes parties prenantes. Basé sur la théorie des parties prenantes et du capital marque, ce chapitre développe un modèle de mesure et un outil de contrôle de la valeur des marques territoriales. Les résultats montrent qu'ils coexistent de diverses dimensions de la valeur des marques territoriales, conformes aux attentes des quatre parties prenantes clés qui ont été identifiées. Ces dimensions de valeur incluent des indicateurs économiques, socio-culturels et environnementaux.

Le chapitre 4 offre une comparaison de quatre marques territoriales régionales en Europe ; l'objectif est de comprendre les conditions générales ainsi que les déterminants contextuels qui sont nécessaires pour créer et pour maintenir des marques territoriales. Ce chapitre combine la perspective du marketing avec celle de la sociologie agroalimentaire et du développement endogène rural; il analyse des aspects du management stratégique et opérationnel des quatre marques régionales ainsi que leur contexte spécifique. Les résultats indiquent que plusieurs dimensions d'un encastrement jouent un rôle important pour les marques régionales, telles que l'influence des politiques publiques, les formes de coopération et de gouvernance locale, l'identité territoriale et l'ancrage des acteurs locaux dans leurs territoires. 
Le chapitre 5 est une étude de cas exploratoire du marketing territorial dans la province de Chefchaouen au Maroc, afin de savoir si et dans quelle mesure il serait possible d'y implémenter une marque territoriale comme projet cohérent et collectif de développement territorial. Pour cela, les préconditions et les diverses initiatives vers un marketing territorial sont analysées à trois niveaux d'action (macro, méso, micro). Une attention particulière est donnée à la coopération et aux activités de réseau, au leadership et à l'unité politique, donc aux dimensions qui sont fortement liées à la question de la gouvernance territoriale. L'aperçu principal obtenu du cas de Chefchaouen est qu'une marque collective territoriale pourrait être un instrument utile pour stimuler une coopération entre différents secteurs, mais qu'actuellement les régions au Maroc manquent encore d'autonomie suffisante pour développer leurs propres projets territoriaux.

Le chapitre final s'appuie sur les résultats de la thèse pour souligner les différences conceptuelles entre diverses marques liées aux territoires. La principale conclusion est que - pour pouvoir stimuler le développement du secteur agroalimentaire et territorial - les marques territoriales régionales doivent être considérées comme plus que de purs instruments de marketing, mais comme des processus de développement dynamiques, collectifs et encastrés. Ces aperçus mènent à des implications au niveau conceptuel et théorique, méthodologique ainsi que politique et managérial pour la recherche et la pratique du marketing territorial. Une suggestion majeure pour la future recherche serait d'utiliser la théorie des systèmes complexes pour couvrir la complexité des marques collectives territoriales. 


\section{Samenvatting}

'Place Branding' strategieën die marketing met plaatsen verbinden hebben toenemend aandacht gekregen in de afgelopen twee decennia, zowel in de praktijk als in de theorie. Het wordt aangenomen dat place branding bijdraagt aan de economische, sociale en culturele ontwikkeling van steden, regio's en landen. Maar er bestaat noch een algemeen geaccepteerde definitie noch een solide theoretisch kader voor het place branding onderzoek. Studies hebben zich tot nu toe voornamelijk op landen en steden gericht, terwijl de regionale dimensie eerder verwaarloosd werd. Verder is er tot nu toe weinig bekend over de condities, processen en uitkomsten van place branding.

Het doel van deze thesis is bij te dragen aan de verduidelijking van het place branding concept en het begrijpen van dit rijke en complexe fenomeen. De nadruk ligt op de ten grondslag liggende condities, processen en dynamieken van place branding in regio's, dat tot lokale ontwikkeling bijdraagt. Place branding onderzoek is hier gericht op lokale levensmiddelen en toerisme ten behoeve van een duurzame ontwikkeling in Mediterrane landelijke regio's (in Frankrijk en Marocco).

De introductie (hoofdstuk 1) schetst de maatschappelijke en theoretische context van place branding in het kader van deze thesis. Place brands zijn tevoorschijn gekomen als pogingen om op - met elkaar vervlochten en veelzijdige - economische, politieke en socio-culturele uitdagingen te reageren. Deze betreffen de gevolgen van de globalisering, op lokale uitdagingen in verband met regionalisering- en decentraliserings-processen, en op socio-economische spanningen in Mediterrane landen en hun unieke voedseldomain. Bijgevolg worden drie literaire stromingen beschouwd: de marketing en branding van plaatsen, regionale studies en sociologie. Hier wordt gesteld dat inzichten in de drie disciplines nodig zijn om de condities, processen en (ontwikkelings-)uitkomsten van regionale merken te begrijpen. Dit leidt tot drie analyseeenheden: (i) de behandeling van place branding in de enge zin en haar beschouwing als marketingstrategie voor de ontwikkeling van plaatsen en hun lokale assets, gebaseerd op een unieke territoriale identiteit; (ii) het bestuderen van territoriale ontwikkeling beleidsvormen en publiek-private interacties; (iii) het analyseren van plaatselijke, collectieve en sociaal ingebedde processen tussen verschillende actoren in landelijke regio's. 
Hoofdstuk 2 omvat een casestudy van het Sud de France merk in de regio Languedoc-Roussillon, welke voornamelijk gebruikt wordt om lokale wijnen, levensmiddelproducten en toerisme te verwaarden en te promoten. Het is een studie van de lokale dynamieken en het proces van place branding, wat positieve uitkomsten oplevert die teruggaan op een publieke interventie. Het toont verschillende economische en niet-economische voordelen die gecreëerd worden door een regionaal merk en laat een aantal van zijn onderliggende werkingsmechanismen zien, zoals horizontale en verticale relaties tussen verschillende territoriale actoren, een betrokkenheid van meerdere stakeholders, of die vervlechting van het regionale merk met zijn politieke, sociale en economische context.

Hoofdstuk 3 is een voortzetting van hoofdstuk 2; hier wordt verder onderzoek gedaan naar de waarde die een regionaal merk kan creëren voor diverse doelgroepen; dit aan de hand van de Sud de France case. Gebaseerd op theorieën over stakeholders en waarde van merken (brand equity), wordt een metingsmodel en een sturingsinstrument ontwikkeld voor de waarde van regionaalmerken. De resultaten laten zien dat regionaalmerken verschillende waardedimensies hebben, conform de verwachtingen van de vier eerder geïdentificeerde belangrijkste stakeholder groepen. Deze waardedimensies omvatten economische, socio-culturele en ecologische indicatoren.

Hoofstuk 4 richt zich op het vergelijken van vier regionale branding initiatieven in Europa, met het doel inzichten te krijgen over generieke condities alsook contextafhankelijke factoren die nodig zijn om regionale merken met succes te ontwikkelen en te behouden. Hier wordt een marketing perspectief met de sociologie van voedsel en endogene landelijke ontwikkeling gecombineerd. Tevens wordt een analyse uitgevoerd over het strategische en operationele management van merken alsook contextuele factoren. De resultaten geven aan dat verschillende dimensies van 'embeddedness' voor regionale merken belangrijk zijn, zoals publiek beleid, samenwerking en bestuur, territoriale identiteit en een verankering van lokale actoren in hun plaats. 
Hoofdstuk 5 is een exploratieve casestudy van place branding in de provincie Chefchaouen, Marokko, om te weten te komen of en hoe het mogelijk zou zijn om een regionaal merk als coherent en collectief ontwikkelingsproject te implementeren. Hier worden de basisvoorwaarden en verschillende initiatieven richting place branding op drie niveaus onderzoekt (macro, meso, micro). Bijzondere aandacht wordt gegeven aan lokale samenwerking en netwerk activiteiten, aan leiderschap en politieke eenheid; dus aspecten die vooral aan de vraag naar territoriaal bestuur gebonden zijn. Het belangrijkste inzicht van de Chefchaouen case is dat een collectief regionaal merk een bruikbaar instrument voor sector-overschrijdende samenwerking, territoriaal bestuur en ontwikkeling zou kunnen zijn, maar dat regio's in Marokko tegenwoordig nog te weinig autonomie hebben om hun eigen territoriale projecten te ontwikkelen.

Het slothoofdstuk bouwt voort op de resultaten van het gehele onderzoek om conceptuele verschillen tussen diverse merken, die aan plaatsen gebonden zijn, te benadrukken. De centrale conclusie van deze thesis is dat regionale merken - om een agro-industriële en lokale ontwikkeling te kunnen steunen - niet alleen als pure marketing instrumenten beschouwd moeten worden, maar veelmeer als dynamische, collectieve en sociaal ingebedde territoriale ontwikkelingsprocessen. Deze inzichten leiden tot implicaties voor het concept en de theorie, de methodologie zoals voor een beleid en management van place branding onderzoek en praktijk. Een eerste suggestie is de theorie van complexe systemen te gebruiken voor verder onderzoek om de complexiteit van regionale merken te doorgronden. 


\section{Zusammenfassung}

Strategien des 'Place Branding' (dt. auch Ortsmarketing), die Marketing mit Orten in Verbindung setzen, haben in den letzten zwei Jahrzehnten in der Praxis und der Theorie zunehmend Aufmerksamkeit auf sich gezogen. Im Allgemeinen wird angenommen, dass Place Branding zur ökonomischen, sozialen, politischen und kulturellen Entwicklung von Städten, Regionen und Ländern beiträgt. Bislang gibt es jedoch weder eine allgemein akzeptierte Definition noch einen fundierten theoretischen Rahmen für die Place Branding Forschung. Bisherige Arbeiten haben sich hauptsächlich auf Länder- und Städtemarketing bezogen, während die regionale Ebene eher vernachlässigt wurde; dies gilt vor allem im Kontext Mediterraner Länder. Außerdem ist bislang wenig bekannt über die Voraussetzungen, Prozesse und Auswirkungen von Place Branding.

Das Ziel dieser Doktorarbeit ist es, zu einer Verdeutlichung der Konzeptes Place Branding und zu einem breiteren Verständnis dieses reichen und komplexen Phänomens beizutragen. Der Schwerpunkt liegt dabei auf den zugrundeliegenden Bedingungen, Prozessen und Dynamiken des Place Branding in Regionen, das zu lokaler Entwicklung beiträgt. Place Branding bezieht sich hier auf regionale Lebensmittel und Tourismus mit dem Ziel nachhaltiger lokaler Entwicklung in mediterranen ländlichen Regionen (in Frankreich und Marokko).

Die Einleitung (Kapitel 1) gibt einen Überblick über den gesellschaftlichen und theoretischen Kontext von Place Branding in Zusammenhang mit dieser Arbeit. Place Brands (Ortsmarken) sind als Reaktion auf miteinander verwobene und vielfältige ökonomische, politische und soziokulturelle Herausforderungen entstanden: auf die Auswirkungen der Globalisierung, auf Herausforderungen die durch Regionalisierung- und Dezentralisierungsprozesse entstanden sind und auf sozio-ökonomische Spannungen im Mittelmeerraum und dessen Lebensmittelbereich. Dementsprechend werden hier drei Literaturströmungen herangezogen: das Marketing und Branding von Orten, Regionalstudien und Soziologie. Dies beruht auf der Annahme, dass Erkenntnisse von allen drei Disziplinen zum Verständnis der zugrundeliegenden Bedingungen, Prozesse und der Auswirkungen von Regionalmarken auf lokale Entwicklung benötigt werden. Dies führt konsequenterweise zu drei Analyseeinheiten: die erste befasst sich mit Place Branding im engen Sinn und versteht dieses als Marketingstrategie für Orte und deren lokale Ressourcen, auf der Basis einer unverwechselbaren lokalen Identität; die zweite betrachtet lokale Entwicklungspolitik und öffentlich-private Zusammenarbeit; und die dritte analysiert lokale, 
kollektive und sozial eingebettete Prozesse zwischen unterschiedlichen Aktoren in ländlichen Regionen.

Kapitel 2 beinhaltet eine Fallstudie der Marke Sud de France der Region Languedoc-Roussillon, eine Marke, die in erster Linie benutzt wird um lokale Weine, Lebensmittel und Tourismus aufzuwerten und zu vermarkten. Es ist eine Studie über lokale Dynamik und den Prozess des Regionalmarketing, dessen vorteilhafte Auswirkungen auf eine öffentliche Intervention zurückgehen. Sie zeigt, wie eine Ortsmarke unterschiedliche ökonomische und nichtökonomische Vorteile schafft und legt deren Wirkungsmechanismen offen, wie z.B. horizontale und vertikale Beziehungen zwischen unterschiedlichen lokalen Aktoren, das Einbeziehen verschiedener örtlicher Interessensgruppen oder die Verflechtung der Regionalmarke mit ihrem politischen, sozialen und ökonomischen Kontext.

Kapitel 3 ist insofern eine Fortsetzung von Kapitel 2, als es der Frage nach der Art des Wertes, die durch eine Ortsmarke geschaffen wird, sowie dessen Zielgruppen anhand der Marke Sud de France weiter nachgeht. Ausgehend von Stakeholder- und Markenwert-Theorien wird in diesem Kapitel ein Messmodell sowie ein Kontrollinstrument für den Wert von Regionalmarken entwickelt. Ergebnisse zeigen, dass unterschiedliche Wertedimensionen gleichzeitig existieren, entsprechend den Erwartungen von vier vorab identifizierten wichtigen Interessensgruppen der Regionalmarke. Diese Wertedimensionen umfassen ökonomische, sozio-kulturelle und ökologische Indikatoren.

Kapitel 4 bietet einen Vergleich zwischen vier regionalen Branding-Initiativen in Europa, mit dem Ziel, sowohl Einblicke in die allgemeinen Voraussetzungen als auch kontext-spezifischen Faktoren für ein erfolgreiches Entwickeln und Managen von Regionalmarken zu erlangen. Dieses Kapitel kombiniert eine Marketingperspektive mit der Soziologie von Lebensmitteln und endogener ländlicher Entwicklung; es untersucht Aspekte des strategischen und operationellen Markenmanagements sowie kontextuelle Faktoren. Die Ergebnisse legen die Erkenntnis nahe, dass eine Einbettung von Marken in verschiedener Hinsicht von Bedeutung ist: in die öffentliche Politik, die örtliche Zusammenarbeit und in neue Verwaltungsformen, wichtig ist aber nicht weniger eine Berücksichtigung der territorialen Identität und die Verankerung lokaler Aktoren mit ihren Orten. 
Kapitel 5 ist eine explorative Fallstudie von Place Branding in der marokkanischen Provinz Chefchaouen, um zu ermitteln ob und wie es möglich wäre, dort eine Regionalmarke als kohärentes und kollektives lokales Entwicklungsprojekt zu implementieren. Dafür werden Grundvoraussetzungen und unterschiedliche Initiativen in Richtung Place Branding auf drei Wirkungsebenen untersucht (makro, meso, mikro). Besondere Beachtung wird dabei der lokalen Zusammenarbeit und Netzwerkaktivitäten, Leadership und politische Einheit geschenkt, die stark an die Frage einer neuen lokalen Regierungsform gebunden sind. Eine wesentliche Erkenntnis aus dem Fall Chefchaouen ist, dass eine kollektive Marke durchaus ein nützliches Instrument für eine sektorenübergreifende Zusammenarbeit, neue Verwaltungsformen und für regionale Entwicklung sein könnte, die Untersuchungen ergaben aber auch, dass die Regionen in Marokko noch nicht über eine ausreichende Autonomie verfügen um ihre eigenen lokalen Projekte zu entwickeln.

Das abschließende Kapitel stützt sich auf die Hauptergebnisse der Arbeit, um konzeptuelle Unterschiede zwischen verschiedenen Regionalmarken hervorzuheben. Die Hauptschlussfolgerung ist, dass Regionalmarken - damit sie agroindustrielle und lokale Entwicklungen fördern können - nicht nur als reine Marketinginstrumente betrachtet werden dürfen, sondern vielmehr als dynamische, kollektive und sozial eingebettete territoriale Entwicklungsprozesse. Diese Erkenntnisse haben Auswirkungen auf Konzept und Theorie, Methode, sowie Politik und Management von Place Branding, in der Forschung als auch in der Praxis. Ein Vorschlag für weitere Forschungen an diesem Thema wäre, die Theorie von komplexen Systemen anzuwenden, um die Vielschichtigkeit der Bedeutung und Anwendungs-möglichkeiten von Regionalmarken zu erfassen. 


\section{About the author}

Mechthild Donner was born in Karlsruhe, Germany, on 14 November 1975. She studied German, French and Spanish Philology at the Universities Munich, Clermont-Ferrand, Sevilla and Freiburg, where she obtained her State Examination Diploma and a Magister Artium in 2002/2003. Afterwards, she completed a Master of Business Administration at Reutlingen University in 2006 with specialisation in International Marketing and a master thesis about sustainable tourism in the national park of Doñana in Andalusia, Spain.

From 2006-2009, she worked in the Netherlands, first as language trainer of business German for professionals at Regina Coeli Talen Instituut (Vught) and then as sales and marketing assistant at Struik Foods Europe (Voorthuizen).

Since 2010, she lives with her husband and daughter in Montpellier, France. Here, she started her $\mathrm{PhD}$ project in 2012 at Montpellier SupAgro (International Centre for Higher Education in Agricultural Sciences) and Wageningen University within the European Joint Doctorate Program AGTRAIN (Agricultural Transformation by Innovation). 
Mechthild Irmgard Maria Donner

Wageningen School of Social Sciences (WASS)

Completed Training and Supervision Plan
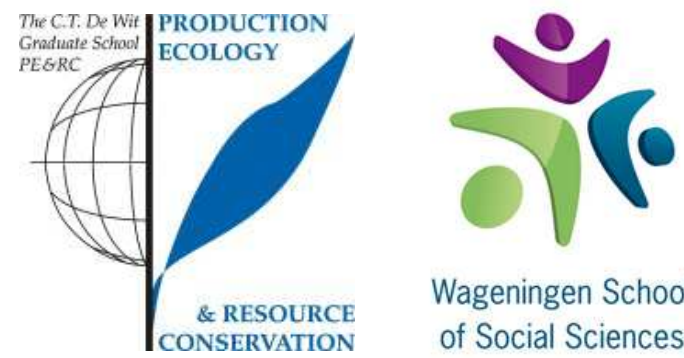

Wageningen School of Social Sciences

\begin{tabular}{|c|c|c|c|}
\hline Name of the learning activity & Department/Institute & Year & ECTS* \\
\hline \multicolumn{4}{|l|}{ A) Project related competences } \\
\hline Writing of research proposal (AGTRAIN) & SUpAGRO / WUR & 2012 & 6 \\
\hline AGTRAIN - introduction course & Un. Copenhagen & 2013 & 2 \\
\hline AGTRAIN Field course & Un. Copenhagen & 2012 & 10 \\
\hline \multicolumn{4}{|l|}{ B) General research related competences } \\
\hline Economies institutionelles & EDEG & $2012-13$ & 1.5 \\
\hline Innovation, PME et entreprenariat & EDEG & $2012-13$ & 1 \\
\hline Cadres theoriques: organisation research & EDEG & 2013-14 & 1 \\
\hline Qualitative research methods & EDEG & $2012-13$ & 1 \\
\hline Method and research techniques (MISTeR) & INRA & 2012 & 1 \\
\hline $\begin{array}{l}\text { Supervised reading: French and English literature } \\
\text { about 'institutional entrepreneurship' }\end{array}$ & WUR & 2013 & 1 \\
\hline Quantitative methods and analysis (SPSS) & EDEG & $2014-15$ & 1 \\
\hline Formation NVivo & EDEG & 2014 & 0.5 \\
\hline $\begin{array}{l}\text { 'Potential and limits for developing a place brand } \\
\text { as tool for territorial development in Morocco: } \\
\text { Case study insights from Chefchaouen' }\end{array}$ & $\begin{array}{l}\text { International Conference of the } \\
\text { Regional Studies Association, } \\
\text { Piacenza, Italy }\end{array}$ & 2015 & 1 \\
\hline $\begin{array}{l}\text { 'Marketing territorial et développement local? Le } \\
\text { cas de Chefchaouen, Maroc' }\end{array}$ & $\begin{array}{l}\text { International Conference of the } \\
\text { 'Association de Science Régionale } \\
\text { de Langue Française', Montpellier, } \\
\text { France }\end{array}$ & 2015 & 1 \\
\hline $\begin{array}{l}\text { 'Collective action for joint agrifood and tourism } \\
\text { marketing in Chefchaouen, Morocco' }\end{array}$ & $\begin{array}{l}\text { International Conference of the } \\
\text { European Society for Rural } \\
\text { Sociology (Scotland) }\end{array}$ & 2015 & 1 \\
\hline Several Presentations & $\begin{array}{l}\text { MOISA (Montpellier), University Cadi } \\
\text { Ayyad (Marrakech), Institut } \\
\text { Agronomique Méditerranéen de } \\
\text { Montpellier (IAMM), Management } \\
\text { Group at University of Montpellier, } \\
\text { and Rural Sociology group } \\
\text { Wageningen University }\end{array}$ & $\begin{array}{l}2014- \\
2015\end{array}$ & 1 \\
\hline \multicolumn{4}{|c|}{ C) Career related competences/personal development } \\
\hline $\begin{array}{l}\text { Contribution to EU7 proposal (Horizon2020) } \\
\text { 'Social innovations for the sustainable } \\
\text { development of rural areas'(SOLID) }\end{array}$ & & 2015 & 1 \\
\hline
\end{tabular}

Total

* One credit according to ECTS is on average equivalent to 28 hours of study load 


\section{Funding}

This thesis was performed in the framework of the Agricultural Transformation by Innovation (AGTRAIN; www.agtrain.eu) Erasmus Mundus Joint Doctorate Program, funded by the EACEA (Education, Audiovisual and Culture Executive Agency) of the European Commission.

Cover design and printing: Print Service Ede 

